\title{
ABET accreditation criteria, Outcome $h$ and global competencies in engineering education
}

\author{
Elisabeth Sanchez-Goni \\ West Virginia University
}

Follow this and additional works at: https://researchrepository.wvu.edu/etd

\section{Recommended Citation}

Sanchez-Goni, Elisabeth, "ABET accreditation criteria, Outcome h and global competencies in engineering education" (2009). Graduate Theses, Dissertations, and Problem Reports. 2934.

https://researchrepository.wvu.edu/etd/2934

This Dissertation is protected by copyright and/or related rights. It has been brought to you by the The Research Repository @ WVU with permission from the rights-holder(s). You are free to use this Dissertation in any way that is permitted by the copyright and related rights legislation that applies to your use. For other uses you must obtain permission from the rights-holder(s) directly, unless additional rights are indicated by a Creative Commons license in the record and/ or on the work itself. This Dissertation has been accepted for inclusion in WVU Graduate Theses, Dissertations, and Problem Reports collection by an authorized administrator of The Research Repository @ WVU.

For more information, please contact researchrepository@mail.wvu.edu. 


\title{
ABET ACCREDITATION CRITERIA, OUTCOME H AND GLOBAL COMPETENCIES IN ENGINEERING EDUCATION
}

By

\author{
Elisabeth Sánchez-Goñi
}

Dissertation submitted to the College of Human Resources and Education At West Virginia University In partial fulfillment of the requirements

For the degree of

\author{
Doctor of Education \\ In \\ Educational Leadership Studies \\ Approved by \\ Ernest Goeres, Ph. D., Chair \\ Paul Chapman, Ph. D. \\ Sebastián Díaz, Ph. D., J.D. \\ Don Lyons, Ph. D. \\ Anne Nardi, Ph. D. \\ Sam Stack, Ph.D. \\ Department of Educational Leadership Studies
}

Morgantown, West Virginia University

2009

Keywords: ABET EC2000, Accreditation Criteria, Outcome h, Global Competencies, Engineering Education, Globalization, International Experience.

Copyright 2009 Elisabeth Sánchez-Goñi 


\title{
ABSTRACT \\ ABET ACCREDITATION CRITERIA, OUTCOME H AND GLOBAL COMPETENCIES IN ENGINEERING EDUCATION
}

\author{
ELISABETH SÁNCHEZ-GOÑI
}

The dissertation focuses on one aspect of the accreditation process of engineering programs in the United States, which is conducted under the standards of the Accreditation Board for Engineering and Technology (ABET). Engineering programs seeking accreditation are required to comply with the so called Engineering Criteria 2000 (EC2000), which has been divided into eleven "learning outcomes," labeled a through $\mathrm{k}$. The dissertation addresses one of them, "Outcome h", which specifically calls for "the broad education necessary to understand the impact of engineering solutions in a global, economic, environmental, and societal context.”

The dissertation examines what engineering departments, from the Southern Regional Educational Board (SREB) area, are doing to comply with Outcome h requirements for accreditation. Thus the purpose of this study is to examine the approaches engineering departments are using to respond to the challenges posed by Outcome h, and what impact this has had in the acquisition of global competencies by engineering graduates, as perceived by chairs of their engineering programs.

The data obtained were analyzed using both inferential and descriptive statistics, which produced significant findings in understanding the situation of engineering departments after the implementation of criteria Outcome h. Although engineering departments have very similar ways of operating, there is no unanimity on what constitutes an adequate response to the challenge posed by Outcome $h$ in engineering. The difficulty comes, in part, from the conceptual confusion about the meaning of international education for engineers and global awareness. However, some contradiction appears as to what constitutes the best way to acquire global competencies. 


\section{ACKNOWLEDGEMENTS}

La tentation la plus grande: ne ressembler à rien.

Alkert Camus

El que tiene fe en sí misma na necesita que las demás crean en él. Miguel de Unamuna

First, I would like to acknowledge my father Christophe Sánchez Palomares and my mother Iluminada Goñi Ibañez for their unconditional support.

Second, I would like to acknowledge my daughters Andréa and Véronique as well as my husband Victor for their unquestionable love.

Last but not least, I would like to acknowledge my director of thesis; Dr. Ernest Goeres and the doctoral committee; Drs. Anne Nardi, Paul Chapman, Sam Stack with special thanks to Dr. Sebastián Díaz and with absolute gratitude to Dr. Donald Lyons for keeping me focused and confident all along. 


\section{Table of Contents}

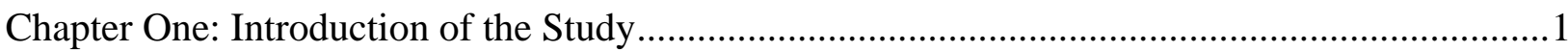

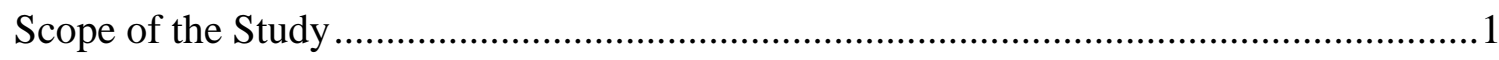

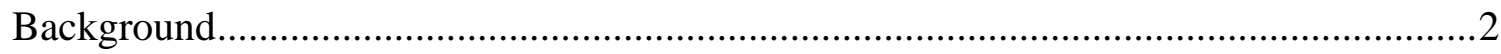

Purpose of the Study ..................................................................................................

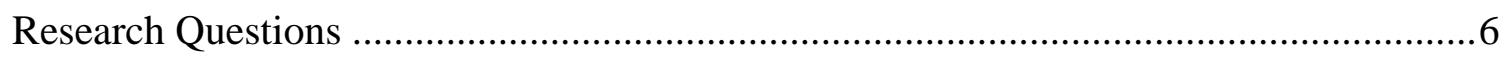

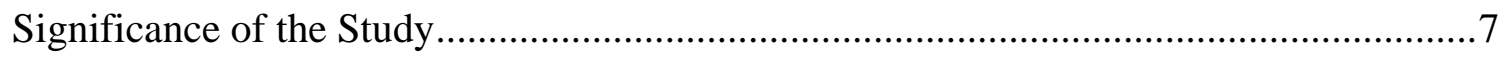

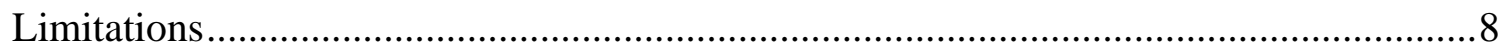

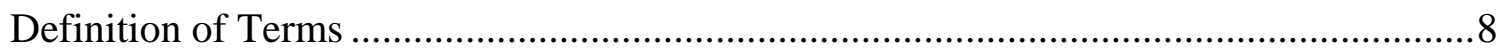

Chapter Two: Review of the Literature ................................................................................11

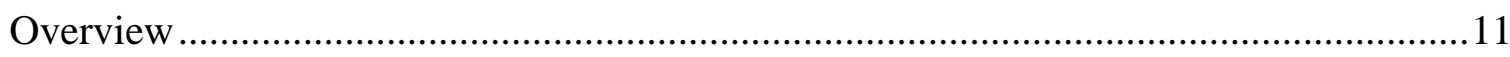

Globalization and Internationalization in Higher Education ...............................................11

The significance of globalization .......................................................................11

The significance of internationalization for higher education institutions ...........13

Institutional frameworks of international education .............................................15

Impact of globalization on higher education global competence teaching ...........17

Impact of globalization on the workplace ............................................................19

A Brief Engineering Education History and ABET EC2000 Accreditation Process ........19

Engineering education .....................................................................................19

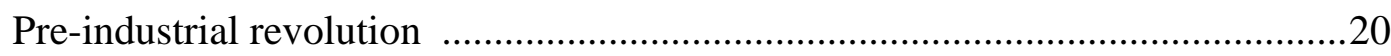

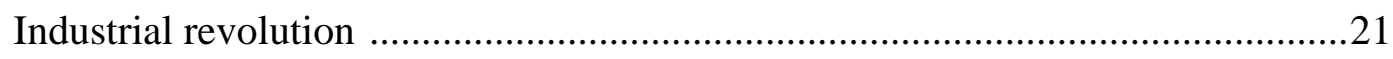

The second industrial revolution …………………........................................21 


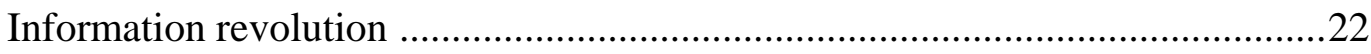

History of ABET and engineering education ....................................................23

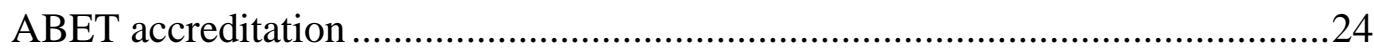

Engineering Accreditation Criteria EC2000 and Outcome h......................................28

Process and awareness skills .................................................................28

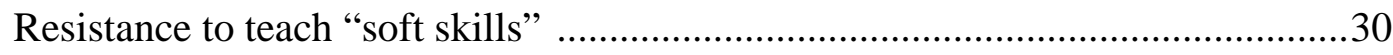

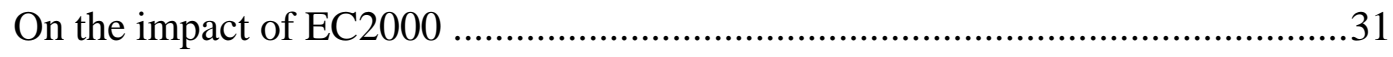

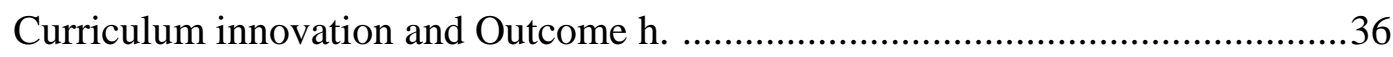

Outcome $\mathrm{h}$ and international experience ....................................................40

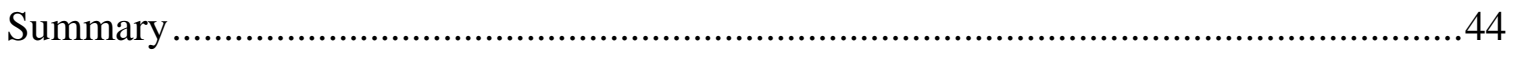

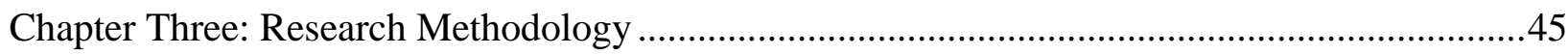

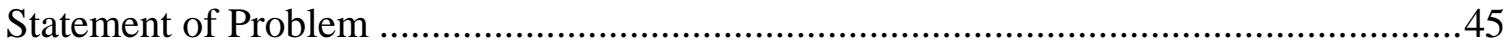

Research Question One......................................................................................46

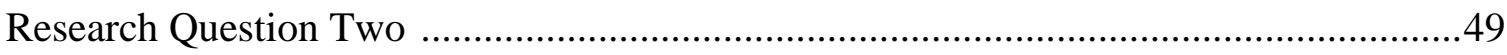

Research Question Three ...............................................................................5

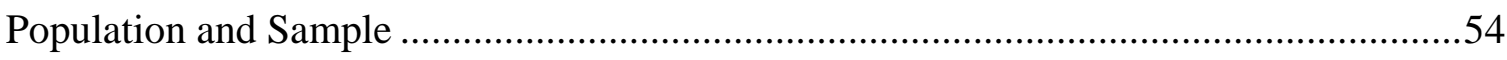

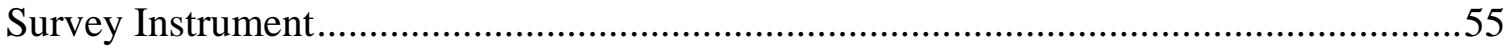

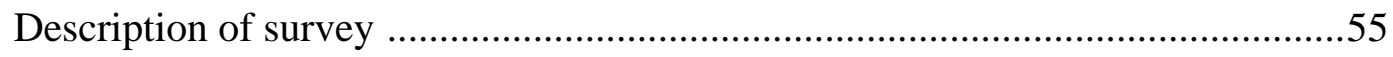

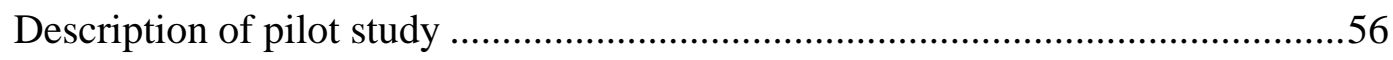

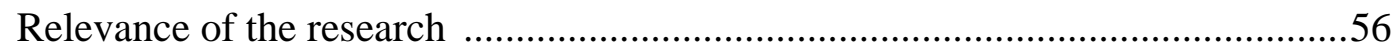

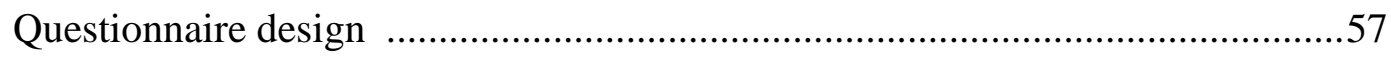

Rewording of the items for better understanding .........................................57 


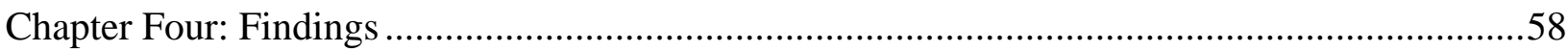

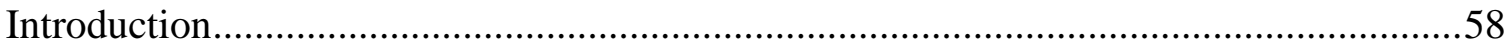

Research Question One.......................................................................................60

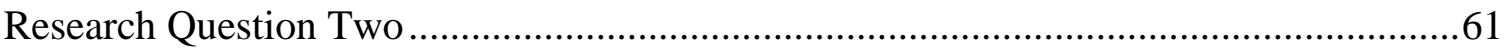

Research Question Three .................................................................................61

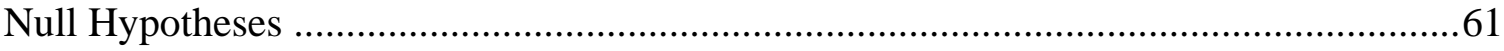

Research Question One - One-Factor Independent Measures ANOVA.........................62

Global competency attention \#1 (see Appendix F) ......................................62

Global competency attention \#2 ............................................................62

Global competency attention \#3 (see Appendix G ........................................64

Global competency attention \#4 ( see Appendix H) ......................................64

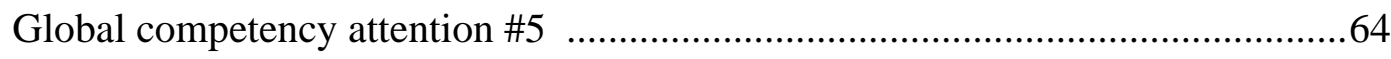

Summary Research Question One - Global Competency Attention..............................66

Research Question Two - One-Factor Independent Measures ANOVA .........................68

Global competency performance \#1 (see Appendix I) ....................................68

Global competency performance \#2 (see Appendix J) ....................................69

Global competency performance \#3 (see Appendix K) ...................................69

Global competency performance \#4 (see Appendix L) ..................................69

Global competency performance \#5 (see Appendix M) ..................................69

Summary Research Question Two - Global Competency Performance .........................70

Global competency performance \#4 (see Appendix L) ..................................70 
Research Question Three - Multiple Regressions Analysis .......................................70

Multiple regressions global competency \#1 (see Appendix N) ...........................70

Multiple regressions global competency \#2 …...............................................71

Multiple regressions global competency \#3 (see Appendix O) ...........................74

Multiple regressions global competency \#4 (see Appendix P) ...........................74

Multiple regressions global competency \#5 (see Appendix Q) ..........................74

Summary Research Question Three - Multiple Regressions Analysis ............................75

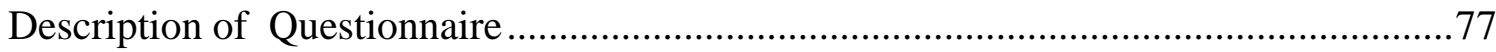

Analysis of the Survey Results - Survey Section 1, 2 and 3 .....................................77

Analysis of the Survey Results - Survey Section 4 (Matrix) ....................................79

Matrix - analysis of item questions 1 through 5 .............................................79

Descriptive results item questions 1 through 5 ...........................................79

Analysis of the Survey Results - Survey Section 5 (Matrix) …..................................83

Matrix - analysis of item questions 6 through 10 ...........................................83

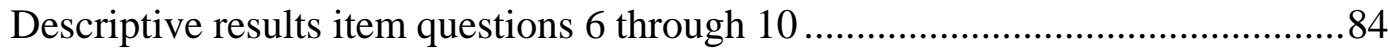

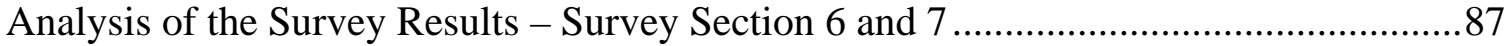

Analysis of the Survey Results - Survey Section 8 ..............................................90

Open-Ended Question - Survey Section 9 ..............................................................93

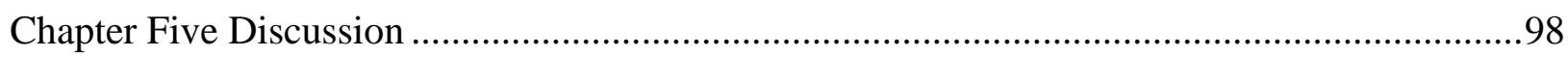

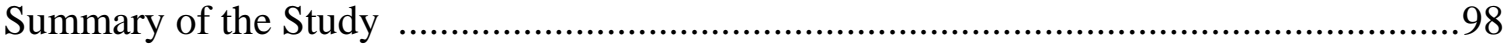

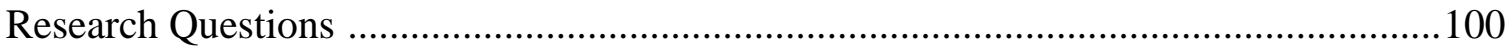

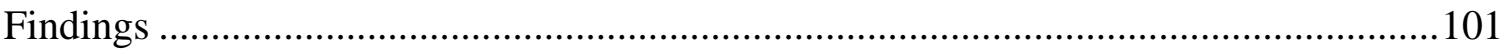

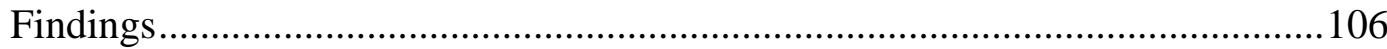


Findings on international experience ................................................................106

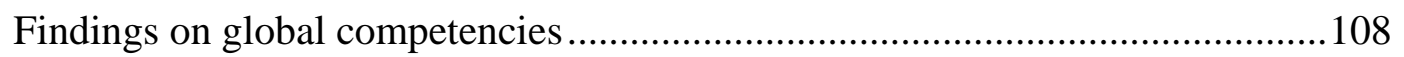

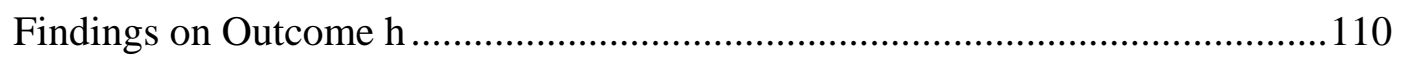

Findings on engineering programs and global competencies ...............................111

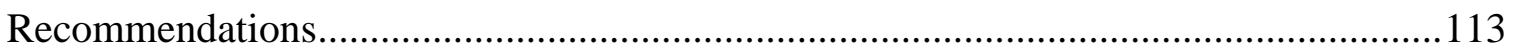

Recommendations for practice ..............................................................113

Recommendations for future research ...................................................113

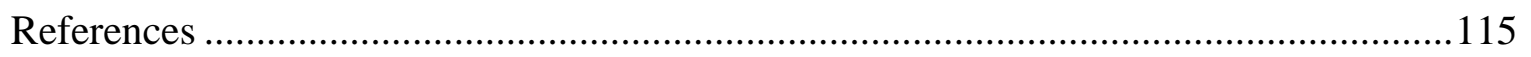

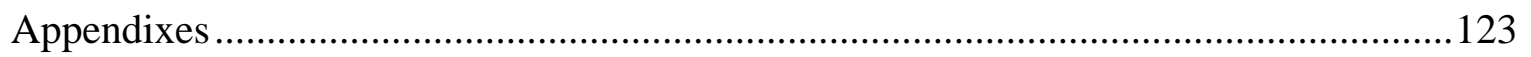

Appendix A: Engineering Education Coalition and Participating Institutions ............123

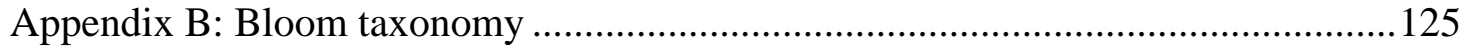

Appendix C: SREB (Southern Regional Education Board) Public Four-Year

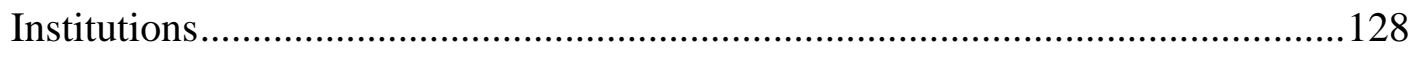

Appendix D: Letter of Informed Consent and Survey Protocol ..................................129

Appendix E: Engineering Education ABET - EC2000 Outcome H, and Global

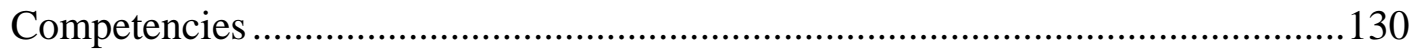

Appendix F: One-Way ANOVA - Global Competency Attention \#1,

Table 6

Appendix G: One-Way ANOVA - Global Competency Attention \#3,

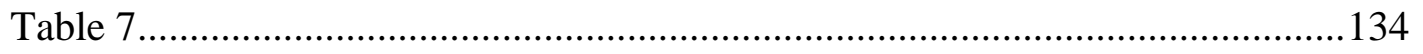

Appendix H: One-Way ANOVA - Global Competency Attention \#4,

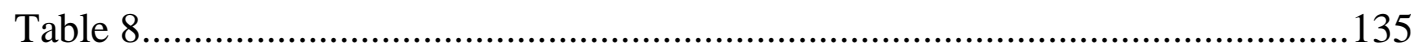

Appendix I: One-Way ANOVA - Global Competency Performance \#1, 
Table 9 .

Appendix J: One-Way ANOVA - Global Competency Performance \#2,

Table 10 .

Appendix K: One-Way ANOVA - Global Competency Performance \#3,

Table 11 138

Appendix L: One-Way ANOVA - Global Competency Performance \#4,

Table $12 \ldots$

Appendix M: One-Way ANOVA - Global Competency Performance \#5,

Table 13.

Appendix N: Multiple Regression - Global Competency \#1,

Table 14. 141

Appendix O:Multiple Regression - Global Competency \#3,

Table 15 143

Appendix P:Multiple Regression - Global Competency \#4,

Table 16. 145

Appendix Q: Multiple Regression-Global Competency \#5,

Table 17. 147 


\section{List of Tables}

Table 1 Course-Outcome Matrix Sample ...................................................................26

Table 2 Global Competency Attention \#2 …................................................................62

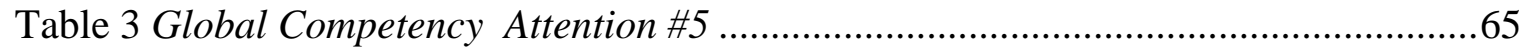

Table 4 Multiple regressions global competency \#2 .................................................... 72 


\section{List of Figures}

Figure 1. Technology and Number of Engineering Student trends after the second

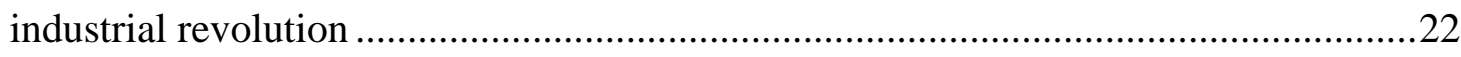

Figure 2. Conceptual Framework for the Engineering Change Study ............................32

Figure 3. Different Results between engineering graduate cohorts on

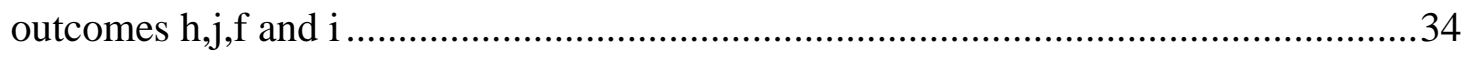

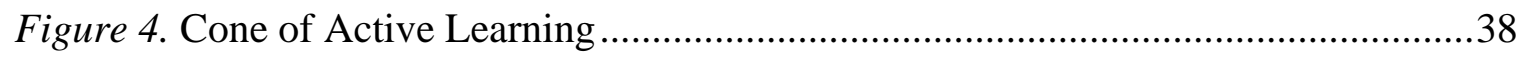

Figure 5. Ability to work in different international settings........................................81

Figure 6. Awareness of global changes and issues driving these changes ......................81

Figure 7. Knowledge of global organizations and business activities............................82

Figure 8. Capacity of effective communication across cultural and linguistic

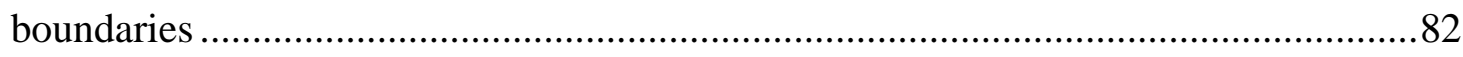

Figure 9. Personal adaptability to diverse culture ....................................................83

Figure 10. Ability to work in different international settings .......................................85

Figure 11. Awareness of global changes and issues driving these changes ....................85

Figure 12. Knowledge of global or organizations and business activities ......................86

Figure 13. Capacity of effective communication across cultural and linguistic

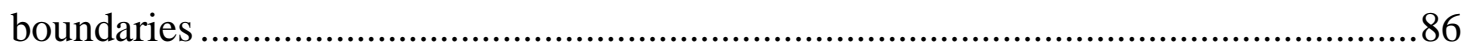

Figure 14. Personal adaptability to diverse cultures..................................................87

Figure 15. Survey Question 6 - Are there any specific courses in your Program that

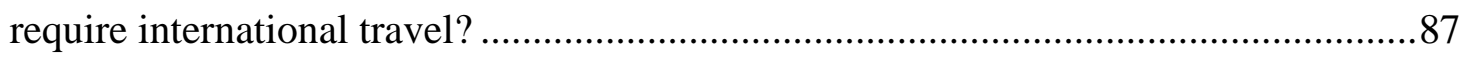

Figure 16. Survey Question 7 - What do you think should be the best way to prepare

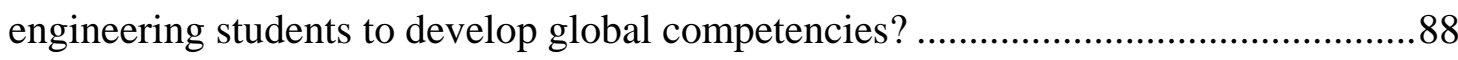


Figure 17. Survey Question 8 - How is your Department (PRIMARILY) preparing engineering students to develop global competencies? (Please, select ONLY one) ....89

Figure 18. Survey Question 14 - We have not done anything differently, BEFORE and AFTER EC2000, regarding Outcome h 90

Figure 19. Survey Question 15 - About Outcome h, we have improved the 91 documentation on what we have been doing all along. 90

Figure 20. Survey Question 16 - We made some changes IN SOME courses to comply with Outcome h.

Figure 21. Survey Question 17 - We made some changes TO OUR curriculum to comply with Outcome h.

Figure 22. Survey Question 18 - We are looking into the curriculum to modify some required courses to add international experiences to comply with Outcome h.

Figure 23. Survey Question 19 - It is very important that our engineering graduates acquire global competencies to comply with Outcome h. 


\section{Chapter One}

Introduction of the Study

Scope of the Study

Globalization trends in general have impacted all orders of life, from the economy and politics to the environment and naturally, education. Engineering education in the $21^{\text {st }}$ Century is particularly challenged to adapt to a rapidly changing technological context in which national borders and distances are less restrictive and where cultures and languages are more relevant. Many commercial products today can be cited as true mosaics of products from all over the world. A single vehicle, for instance, may require components and/or processes from each of the five continents and from as many as twenty different countries.

Just how engineering colleges and more specifically engineering programs are responding to these globalization trends is an issue worth exploring. According to Skip Fletcher (2002), director of ABET, the future of the engineering profession may well depend on whether engineering education is able to initiate and implement strategies to deal with future challenges, particularly in the international arena.

In this dissertation, engineering education is explored in the context of the criteria used for accreditation of engineering programs by the Accreditation Board for Engineering and Technology, also known as ABET. These engineering criteria (adopted in the year 2000) are referred to as “EC2000,” and specifically call for competence to be acquired by engineering graduates as a measurable outcome of their education. EC2000 consist of several outcomes (eleven to fourteen depending on program), one of which is “Outcome h" This criterion is the only one that refers to the requirement of awareness of global issues and global-societal 
competencies in the context of the engineering curricula. The main concern in this research is to determine how ABET accreditation requirements make a difference in terms of the global competencies acquired by engineering graduates.

\section{Background}

Global competencies in higher education have acquired added significance in the last decade in response to globalization trends that affect all aspects of life: political, social, economical, technological, and of course, educational. In 2000, the American Council on Education (ACE) issued a report addressing the leadership role that higher education needed to play in developing a globally literate citizenry and workforce. It emphasized that:

America’s future depends upon our ability to develop a citizen base that is globally competent. The nation's place in the world will be determined by our society-whether it is internationally competent, comfortable, and confident. Will our citizens be competent in international affairs, comfortable with cultural diversity at home and abroad, and confident of their ability to cope with the uncertainties of a new age and a different world? (p.vii)

Engineering graduates in particular are confronting a world that is changing at a fast pace, in which engineers from other countries are doing work overseas through the practice of outsourcing. In addition, many products formerly produced locally are now imported. For these and many other reasons, institutions of higher learning need to produce graduates that are better prepared to meet the challenges of the $21^{\text {st }}$ century global workforce.

Today’s engineering landscape and workplace is so different that universities have adopted new criteria to prepare graduates for successful development in private as well as public 
sectors. What is not clear in engineering education is whether the global competencies of engineering graduates have been afforded their due latitude, despite the fact that among other things:

- Many US companies manufacture here, and then export overseas.

- Many products manufactured in the United States rely on foreign suppliers.

- Many midsize and small engineering companies conduct industrial operations with international partners.

- Many major and midsize companies opt to outsource engineering services to other countries, particularly in Asia.

- Many engineers in the workforce come from other countries and possess different cultures.

In addition, the development of a global economy and instantaneous communications have led to an industrial world which never sleeps, and future professionals in any setting will more likely have more global correspondents than his/her predecessors.

In response to these trends, the National Science Foundation (NSF) organized a series of coalitions (see Appendix A) in the early 1990’s aimed at anticipating the way engineering education could meet the challenges of the $21^{\text {st }}$ Century. Coalitions such as SUCCEED (Southeastern University and College Coalition for Engineering Education) funded from 1992 to 2003 , GATEWAY from 1992 to 2003, GREENFIELD from 1994 to 2005, ECSEL (Excellence in Education and Leadership) from 1991 to 2001, SYNTHESIS from 1990 to 2001 and FOUNDATION from 1993 to 2004 have drawn attention to the undergraduate engineering curricula and learning environment to produce innovative and comprehensive models for 
systematic reform of undergraduate engineering (Froyd \& Frair, 2000). The SUCCEED Coalition in particular has emphasized the international component in engineering education.

In parallel, over the decade of the 1990's, the Accreditation Board of Engineering and Technology (ABET) developed a new and comprehensive set of curriculum standards to accredit undergraduate engineering programs known as ABET “EC2000.” In the United States this agency is responsible for accreditation of educational programs in engineering. The accreditation criteria consist of eleven educational outcomes that provide the basis for guiding engineering programs to successful accreditation. EC2000 emphasizes outcomes of student learning, a vantage point that leads to a more comprehensive approach to the development of human resources and a broader educational experience, in which individual courses and learning experiences are integrated (ASEE, 1998).

ABET (2003) requires engineering programs to demonstrate that graduates exhibit evidence of preparation for a set of eleven competencies (designated as "Outcomes”) for most engineering programs as listed below:

(a) An ability to apply knowledge of mathematics, science, and engineering;

(b) An ability to design and conduct experiments, as well as to analyze and interpret data;

(c) An ability to design a system, component, or process to meet desired needs;

(d) An ability to function on multidisciplinary teams;

(e) An ability to identify, to formulate, and solve engineering problems;

(f) An understanding of professional and ethical responsibility;

(g) An ability to communicate effectively; 
(h) The broad education necessary to understand the impact of engineering solutions in a global and societal context;

(i) A recognition of the need for, and an ability to engage in life-long learning;

(j) A knowledge of contemporary issues;

(k) An ability to use the techniques, skills, and modern engineering tools necessary for engineering practice. (p. 5)

According to Schmidt and Pertmer (2002), the most radical advance of EC2000 is the inclusion of non-technical criteria, now considered important outcomes of an engineering education, which are specifically outcomes $d, f, g, h, i$, and $j$. The objective of these recent changes is to produce engineers that can function in an ever changing world environment with the adequate skills to succeed.

Schools are thus responsible for the creation and implementation of new approaches of teaching engineering in order to reach and document attainment of the aforementioned outcomes. Ollis (1999) considered that the best way to address all the criteria concerning "the practice of engineering in context” (p.3) is better served outside the classroom and in particular in overseas educational opportunities. These international experiences could be of different types, but the skills that the modern workplace demands of engineering practitioners can be easily meet from any “outside practice” (p.3) opportunity that will force a reassessment between the practitioner's competence and the professional's need.

Purpose of the Study

In this dissertation, the focus is on engineering education and the EC2000 Outcome h, which specifically calls for "the broad education necessary to understand the impact of 
engineering solutions in a global, economic, environmental, and societal context.” It is pertinent in the context of this dissertation to examine what engineering departments are doing to satisfy Outcome h requirements for accreditation. Thus the purpose of this study is to examine how engineering departments are responding to the challenges posed by Outcome h, and what impact this has had in the acquisition of global competencies by engineering graduates, as perceived by chairs of their engineering programs.

\section{Research Questions}

Given Outcome h; "the broad education necessary to understand the impact of engineering solutions in a global, economic, environmental, and societal context,” EC2000. Specifically, the following research questions are posed:

1. Is there a significant difference in the attention afforded to Global Competencies Attention (reflected by GCA scores) when comparing engineering departments who primarily use either selected Humanities and Social Sciences courses to satisfy Outcome h, as opposed to adding topics to current engineering courses or by conducting Study Abroad programs in engineering?

2. Is there a significant difference in Global Competency Performance (GCP) scores when comparing engineering departments who primarily use either selected Humanities and Social Sciences courses to satisfy Outcome h, as opposed to adding topics to current engineering courses or by conducting Study Abroad programs in engineering? 
3. Can we predict, in a statistically significant fashion, using regression analysis, an engineering department’s GCP scores from their respective GCA scores?

In addition, other relationships are explored, based on demographic factors, and the like.

\section{Significance of the Study}

Driven by technology, commerce and the environment, globalization trends have had a major impact in the social order in the world. Higher education, specifically in the U.S.A., has not been the exception and has been affected by globalization trends. In this context, the impact of EC2000 in engineering education has been the topic of a number of papers and studies published in various conferences and forums. A study conducted by the Pennsylvania State University (2007) is the prime example of how the EC2000 has impacted engineering curricula. However, global competencies and how they relate to the accreditation process remains an elusive topic that is worth pursuing in the context of this dissertation. In spite of this, it is evident that there exists an increasing demand in the workplace for professionals with global competencies, but what is not clear is if institutions of higher education are doing their share in providing young professionals with those global competencies that are in demand. Specific emphasis is placed on how engineering programs comply with accreditation requirements and the impact on global competencies expected of engineering graduates.

More specifically, it is important to understand if new generations of engineering graduates are acquiring the global competencies implied in "Outcome h" as a result of changes in the curriculum as specified by ABET EC2000. Or alternatively, are engineering programs being accredited (or deemed satisfactory in “Outcome h”) based on documentation on curriculum practices that had been in existence all along. Put more bluntly, has ABET EC2000 induced changes in the curriculum to produce graduates with improved global competencies or, has 
ABET EC2000 produced changes on what is being reported to seek accreditation? The implication of the latter is that new generations of graduates are not acquiring the competencies intended by ABET EC2000 despite the fact that the programs are accredited. This possibility justifies the need for this study.

\section{Limitations}

This study has the following limitations:

1. Only 26 undergraduate engineering Colleges were considered. These 26 undergraduate Colleges belong to the SREB (Southern Regional Educational Board) area (see Appendix B).

2. Only universities with accredited undergraduate engineering programs participated in the study and consequently findings may not be generalized to non-accredited programs. 3. Assessment is based on "perceived” levels of attainment of global competencies by chairmen of engineering departments.

\section{Definition of Terms}

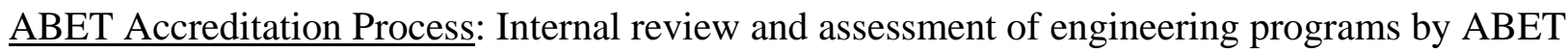
to guarantee the quality of the programs.

ABET: The Accreditation Board for Engineering and Technology is a federation of 28 engineering technical and professional societies that is responsible for the accreditation of engineering programs in United States.

ABET EC2000: The ABET Engineering Criteria of 2000 recommends a new set of criteria for accreditation of United States engineering programs. 


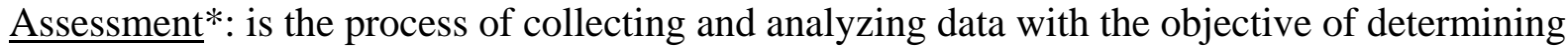
the extent to which a desired Outcome has been achieved or not.

Constituency $^{* *}$ : A group of people with common expectations of an educational program.

Constituency Needs $^{* *}$ : What a constituency expects to get in return for its investment in an educational program.

Engineering Education: Engineering Education is the educational process and formation of future professional engineers.

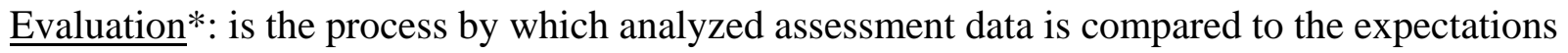
as described by the goals and outcomes. In fact, what is being "evaluated" is to what extent outcomes are achieved or not. The evaluation is performed according to performance criteria.

Evidence*: The documentation produced by students who demonstrate their skill, knowledge, ability, and/or behavior with respect to specific topics. Typical evidences are: Homework, Midterm Exams, Final Exams, Reports, Videotapes of Oral Presentations, Evaluation forms of oral presentations, etc. In our example, the reports form the capstone design projects would be part of the evidence.

Globalization: The act, process, or policy of making something worldwide in scope or application. (American Heritage Dictionary, 1982).

Global Competencies: Global competencies, among many others capacities, are global teamwork skills and the ability to understand the economical and sociopolitical impact of engineering solutions. In this research they are composed of the following: international travel experience related to the engineering profession, awareness of societal impact of global technology, foreign 
cultural awareness and basic foreign language knowledge, awareness of global technology market and economics, and interpersonal skills and creative resourcefulness.

Goals*: are used to subdivide the Outcomes into more manageable and measurable suboutcomes. The Program Outcomes in our example are sub-divided into two goals: \#1 written communications and \#2 oral communications.

International Experiences : are institutional programs at colleges and universities by which engineering student may conduct any of the following activities with academic credit toward completion of an engineering degree; Study Abroad, student exchange programs, faculty led programs, special international programs such as engineers without borders, etc.

Learning Objectives $^{* *}:$ Statement describing specific knowledge and/or skills that students are expected to acquire.

Outcome h: The broad education necessary to understand the impact of engineering solutions in a global, economic, environmental, and societal context.

Program Outcomes ${ }^{* *}$ : Descriptions of the knowledge and/or skills graduates are expected to have after completing the curriculum.

Specified Accreditation Outcomes $^{* *}$ : the 11 outcomes listed in Criterion 3 and required of all engineering programs.

SREB: Southern Regional Education Board that comprises fifteen states: Alabama, Arkansas, Delaware, Florida, Georgia, Kentucky, Louisiana, Maryland, Mississippi, North Carolina, Oklahoma, South Carolina, Tennessee, Texas, Virginia and West Virginia.

\footnotetext{
* Definitions from WVU Mechanical and Aerospace Engineering

** Glossary of terms by ASEE
} 


\section{Chapter Two}

Review of the Literature

\section{Overview}

In this review of literature, the following areas will be discussed: globalization and internationalization in higher education, a brief history of engineering education and ABET EC2000 accreditation process, and Accreditation Criteria EC2000, Outcome h.

\section{Globalization and Internationalization in Higher Education}

The significance of globalization. Globalization is a term that is used interchangeably with internationalization, but both terms describe different concepts that are important to explain in regard to the context of this research on Higher Education.

However and interestingly enough, one point in common between the two definitions is that both phenomena produce change, and change sometimes can be confused with the concept of modernity or progress, which has a totally different philosophical stand.

Globalization expresses the growing changing environment in the economic sphere and the geographical growing interdependence, whereas according to Marginson and Van Der Wende (2006) “internationalization is a more modest process which translates into the conventional regulation between states” (p. 5). In higher education, Marginson et al. (2006) explain that "internationalization has a long history as a relatively safe method of broadening one’s intellectual horizons through reflective comparison” (p.10).

Globalization on the other hand, is a term originally used to describe contemporary economic phenomena that are related to the expansion of a global free market. There are opponents and proponents of the theory of globalization. Many suggest that globalization has 
negative effects on the people around the world, but others think that its new developments are positive. Opponents are concerned with the social and ecological devastations provoked by this type of globalization, whereas proponents argue that globalization will bring prosperity and international collaboration (Schaeffer, 2003). Analysts argue also about the "novelty" of the phenomenon of globalization, observing that economical competition and expansion of economical spheres have existed since the sixteenth century in Europe with the creation of empires and later on with colonization in the late $19^{\text {th }}$ century (Schaeffer, 2003). Fernand Braudel (1979) explained that a world economy is not a global economy and what is experienced today "has nothing in common with previous human experience" (Stromquist, 2002, p. 5). Others (Giddens, 1999; Bourdieu, 1996) argue that globalization is an ideological myth created by "free-marketeers" to deregulate the social state and that the biggest change is in the increasing use of “electronic money that only exist as a digit in computers” that can destabilize solid country’s economies (Giddens, 1999). Carnoy (1999) suggests that the emergence of a global economy has been possible since the mid-1980s with "the technological infrastructure provided by telecommunication information systems, microelectronics machinery, and computer-based transportation, which allows economical activities to function on a planetary scale on real-time” (p.14). Thomas Friedman (2006) explains that from an historical point of view globalization's driving mechanisms can be divided into three eras. The first one (1492 to 1800), that he calls globalization 1.0, was essentially the result of countries competing with each other and international economic opportunities. The second globalization 2.0 era (1800 to 2000) was driven by multinational companies interests and the last one, globalization 3.0 (2000 to present), is "the new found power for individuals to collaborate and compete globally" (p.10). Friedman 
describes our world as a shrinking place where global competition and collaboration is now at an individual level and this phenomenon leads to a flattening process with people all over the globe.

According to Tony Brown (1999) who has a critical view of globalization, the process of change called globalization is threefold: the first one describes "the transfers of money around the world, the production and exchange of services and the declining role of the nation state” (p. 3); the second one refers to globalization as being "an objective entity seemingly with its own conscious purpose” (p. 3) as if it were some kind of "independent active agent” (p. 3). The third conception is related to globalization as a discourse in which the concept is viewed as an inevitable natural process, independent of human influence (Bourdieu, 1996, p. 4).

Most analysts like Schaeffer (2003) and policy makers “use globalization to describe the growth and spread of investment, trade and production, the introduction of new technology, and the spread of democracy around the world” ( p.1).

The significance of internationalization for higher education institutions. The word internationalization in regard to higher education, like the word globalization in the sphere of economics, lacks a firm agreement on its meaning. However, there is an historical antecedent with the Medieval European universities where wandering scholars traveled and studied at different universities across Europe.

Presently in Europe, there is an effort through different European programs such as SOCRATES and ERASMUS (exchanges and scholarly programs) to harmonize the structure of programs of studies and the mobility of students which reminds us of their prestigious predecessors (Altbach, 2004). In the United States, however, the field of international education is "fragmented and compartmentalized" (p. 2) with no unifying theory to consolidate the field (Mestenhauser, 2006). 
Marginson and Van Der Wende (2006) pinpoint that internationalization emphasizes more a collaborative approach than globalization which is more concentrated in economic competitiveness. Competition, however, is not out of the picture for internationalization and particularly for higher education institutions. The economic and trade perspective is becoming central in the support for internationalization.

Two opposing views characterize internationalization: on one hand, the humanistic approach of understanding human similarities and differences, and on the other hand, the increasing importance of the commercial perspective. Organisation for Economic Co-operation and Development (OECD, 1994) conceptualizes the situation by providing an interesting theory based on two models which are respectively called market model and liberal model.

The market model, according to OECD, emphasizes the competition between higher education institutions within a field for financial advantages and marketing positioning at a national and international level. The assumption is that universities compete for ideas, markets, influence and students (Wagner, 2004). By the same token, innovation in education is more for international purposes than regional ones.

The liberal model, in turn, stresses the importance of cooperation between countries in order to improve global consciousness, exchanges and internationalization of curriculum (OECD, 1999). It also recognizes the moral obligation to educate students from underdeveloped countries and considers the presence of foreign students as positive for faculty and fellow students (Tillet \& Lesser, 1992). It is important to stress the different conceptualizations of international education because confusing and contradictory theories abound, and very little has been done to clarify the rationale for their differences. 
Institutional frameworks of international education. Many universities have included the perspective of international education as a goal in their mission statements. This is, usually, the first internationalization effort put in place. Knight (1994) and Harrari (1993) consider that internationalization of higher education should be a process that should infuse the whole campus from University administrators to students and faculty. DeWitt (1999) adds that "the internationalization of higher education is the process of integrating an international/intercultural dimension into the teaching, research and services function of the institution” (p.1). However, the vision of internationalization as a list of activities isolated and with no connection with one another within the realm of the university is what is usually found in most universities in the United States (DeWitt, 1999).

On another hand, John Mallea (1997) observes that Knight and Harrari have conceptualized a list of activities that are believed to be favorable to the implementation of the shared vision of internationalization as a process. The activities are as follows and are intended to facilitate the process oriented approach of internationalization:

- $\quad$ foreign language curriculum study;

- international elements in the curriculum;

- $\quad$ work/Study Abroad opportunities;

- $\quad$ the presence of international students;

- faculty/staff exchange or mobility programs;

- international development assistance programs;

- institutional co-operation agreements;

- joint research projects with transnational partners; 
- $\quad$ area studies;

- cross-cultural training; and

- $\quad$ extra-curricular activities and institutional services. (p. 113)

The National Association of State Universities and Land Grant Colleges (NASULG, 2000) offers seven goals for internationalization to be implemented in the three basic university’s missions which are teaching and learning; research and scholarship; and service and outreach. They are listed as follow:

1. Make internationalization an integral part of the university’s mission and strategic plan;

2. Promote greater involvement of all students in significant international education experiences;

3. Create and maintain a stimulating and supportive academic and cultural environment for international students and scholars;

4. Increase the international activity of faculty and professional staff;

5. Internationalize the curriculum;

6. Assure that research and scholarship pertaining to international matters permeates disciplinary and interdisciplinary fields; and

7. Ensure that international awareness is an integral part of appropriate outreach and extension activities. (p. 4)

The differences of interpretation reveal the selective views held by the various stakeholders about internationalization and their respective self-interest. Faculty, administrators, students, government and private industry share the same interest in developing internationalization but, as previously mentioned, not for the same reasons (Mallea, 1997). 
Impact of globalization on higher education global competence teaching.

Internationalization is a response to globalization. The OECD (1997) observes that internationalization, until now a marginal activity to the institution, is becoming increasingly important in the delivery of education. The recent and growing interest in the internationalization of university is the result of the growing integration and interdependence that are changing the work policies, as we know them. Colleges and universities are feeling the need to respond to this new economic and commercial reality by better equipping their students to live and work in a new world economy by transmitting skills needed in the global economy. Therefore, international knowledge and skills are becoming increasingly important for the future and competitiveness of the country's economy (NAFSA, 2003). These new skills sometimes called global or international competencies converge on the importance for universities to "be organized to respond to the needs of today's students and tomorrow's, not yesterday's” (NASULG, 2000).

There is a large range of definitions on what skills or competencies are important to teach throughout the undergraduate curriculum for engineering students. The Foundation Coalition (FC, 2007) defines these skills as follows:

- knowledge or understanding - awareness of the process,

- Ability in an art, craft, or science - experience with the process, and

- Proficiency, expertness, or judgment - judgment in using the process. http://www.foundationcoalition.org

The American Council on Education (ACE) delivered a powerful statement in 2002, in the wake of the attack on the World Trade Center Towers in New York on September 11, 2001 
emphasizing that global competencies have never been so important to our lives. The definition given in the statement is as follows:

Global competence is a broad term that ranges from the in-depth knowledge required for interpreting information affecting national security, to the skills and understanding that foster improved relations with all regions of the world. It involves, among other things, foreign language proficiency and an ability to function effectively in other cultural environments and value systems, whether conducting business, implementing international development projects, or carrying out diplomatic missions. (p.7)

Brustein (2007) believes that in order for students to achieve global competence, universities should develop a comprehensive and coherent curriculum that will train students to be globally competent critical thinkers. These global competencies are not only useful for security reasons or for global business competition, but also for the development of abilities such as knowing, comprehending, analyzing, and evaluating information in the context of an increasingly globalized world.

Brunstein (2007) isolated several global competencies, as defined by NASULGC report; A Call to Leadership: The Presidential Role in Internationalizing the University, and then simplified by Charles Litalien (2006) as followed:

- Ability to work effectively in different international settings;

- Awareness of major currents of global changes and issues driving these changes;

- Knowledge of global organizations and business activities;

- Capacity of effective communication across cultural and linguistic boundaries;

- $\quad$ Personal adaptability to diverse cultures. 
There are many views and concepts related to the internationalization of universities, but what has become evident is the increased importance of international knowledge or global competence as an indispensable part of education for the $21^{\text {st }}$ century.

Impact of globalization on the workplace. The dramatic restructuring of the economy and the subsequent changes in society explain the mutation occurring in higher education institutions. Flattened hierarchical organizations and polyvalent "knowledge workers” (expression coined by Peter Drucker in 1959) in a changing workplace environment, have influenced the delivery of higher education, particularly for engineering education. Drucker (1994) explains these changes with the dramatic need for knowledge as a tool for technological advantage and economical competitiveness.

Because globalization has changed the work policies in the workplaces, universities have a new role to play in the formation of a new generation of "knowledge worker" or human capital. Human capital is defined as the specific knowledge, experience and talent possessed by a person that contribute to one's productivity and well being (Becker, 1964). Thus, knowledge has become of primordial importance in the international competition and the survival of economic welfare in industrial societies. It has become the key economic resource, and technological societies are creating knowledge societies (Drucker, 1994). In such a knowledge society, knowledge occupies a central position for the preparation of the future global workforce and universities are a key resource for the acquisition of new competencies and capabilities that go beyond the technical expertise and know-how (Natarajan, 2006).

\section{A Brief Engineering Education History and ABET EC2000 Accreditation Process}

Engineers constitute one of the largest professional groups in America. This is also evident by the large number of professional engineering societies including the American 
Society of Engineering Education (ASEE). Engineers use science knowledge, nature, and ingenuity to transform energy and materials to serve human needs. As such, engineers are supposed to be educated in sciences as well as social sciences. The history of engineering is very broad, but can be divided by certain historical events and eras as follows: pre-industrial revolution, industrial revolution, second industrial revolution, and information revolution. The history of ABET and engineering education as well as a description of ABET accreditation process will follow the history section.

Pre-industrial revolution. Ancient engineers were able to create splendid works, like aqueducts and other monuments that have survived the test of time. Engineers of that period understood the relationship between their work and nature, and certainly the impact of their works on society. Engineers of that period were not considered scientists, but they used common sense techniques such as observation, imagination and ingenuity in order to achieve some awesome accomplishments that have impacted humans for generations (Grayson, 1993). An example of ancient engineering application was Alexander’s war machine "ballista,” which means "to throw." This machine used tension and torsion energy stored in ropes made of animal tissue (guts) to launch warheads (Hill, 1984).

Perhaps a landmark was reached when Galileo Galilee and Copernicus established a rational relation between the physical universe they could observe and mathematical descriptions of its dynamics. Physical systems could be represented in mathematical terms as practices that were used in early engineering innovations of which many benefitted society. What is important to note here is that from the beginning, engineers have had a "societal" context on their profession. 
Industrial revolution. During the industrial revolution, the Watt steam engine was invented to replace human or animal effort and the name of the profession was coined as a derivative of engine, or engineer, one who tinkers with engines. But the term “engine” is also related to ingenium (Latin for invention and talent) (Finch, 1960). It is hard to pinpoint where the first formal engineering degree was actually granted, since engineers educated themselves as apprentices, by observation and experimentation. While some formal schools of mines were established early in the continent and brought to America shortly after its colonization, it appears that the first formal degrees in engineering were established in Europe, in France, Italy and England. But by the early 1800’s engineering education was no longer the result of an artisan apprenticeship but the result of formal university education (Grayson, 1980).

The second industrial revolution. This period was characterized by the discovery and utilization of electricity and its application for production in industry. Other areas of engineering which were typically independent became basically intertwined. Electric machines required both mechanical and electrical knowledge and the impact of electro-mechanical devices was felt in industrial practice, in nautical applications, in transportation and in chemical plant processes (Perkins, 1998). Tinkering with engineering ideas formally became research and development and the first post-graduate degrees in engineering appeared in Europe and America (Grayson, 1980). Innovators like James Michael Faraday, Clerk Maxwell, Nikola Tesla and Thomas Alba Edison, provided the basis of today’s modern technology. Technologies and engineering education programs grew and developed in parallel during the first half of the $20^{\text {th }}$ century, as illustrated in the graphs of Figure 1, below. 
Penetration of Technologies

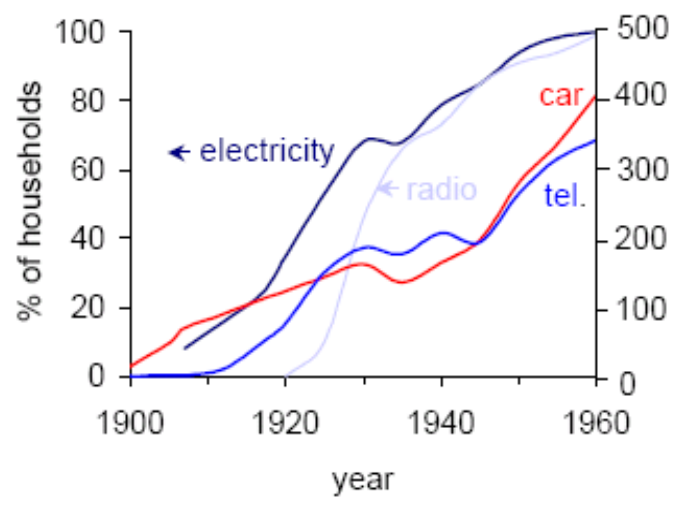

Engineering Student Bodies

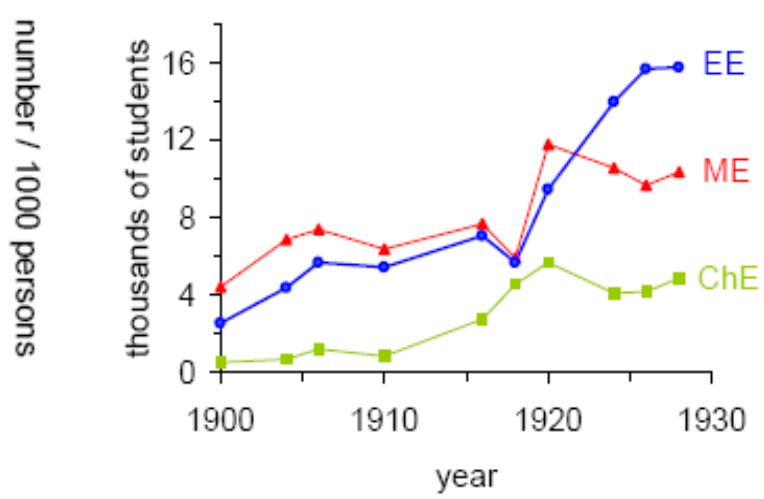

Figure 1. Technology and Number of Engineering Student trends after the second industrial revolution (Historical Statistics of the US, 1975)

(EE=Electrical Engineering, $\mathrm{ME}=$ Mechanical Engineering, $\mathrm{ChE}=$ Chemical Engineering)

Worthy of notice is the invention of dynamite by Alfred Nobel, who realizing the potential harmful uses of his invention decided to establish the "Nobel Peace Prize” in a clear reference to ethical values in science and engineering practice. However, the Nobel Peace Prize did not stop the development of what are now known as weapons of mass destruction, which are in clear conflict with today's ethical values. Again in this example, engineering and societal context are intertwined.

Information revolution. After the Second World War, the "bomb” and the race for space produced a surge of technical development in all scientific branches. Advanced science and engineering became more and more intertwined. Material science and engineering, electronics and the transistor invention, computer science, chemistry, physics and areas such as aerospace, robotics, bioengineering, informatics and economics became commodities that have influenced the geopolitical order and dynamics of the world. In the early 1990's, the development and subsequent explosion of the Internet brought another dimension to communications. The impact of this new technology has made the world virtually borderless. The dynamics of Industry and 
Business have produced a global context for the development and application of technology. The global interconnection is giving the engineering profession (and many others) an intrinsically international dimension. Meanwhile, engineering education has continuously changed its curriculum, which reflects the dynamics of science and technology as a commodity in the world. With the September 11, 2001 events in New York and Washington DC, it is clear that terrorism and crime have also become global enterprises that make use of the most advanced technologies. As a consequence, biometrics, and forensic engineering have become new areas of professional opportunity. This is another example of how engineering responds in a contextual and societal environment.

History of ABET and engineering education. Following the tradition of guilds of the profession, various professional societies came to existence in the United States such as the American Society of Mechanical Engineers (ASME created in 1880), the American Society of Civil Engineering (ASCE created in 1852), the American Institute of Electric Engineers (now IEEE created in 1884), etc. Others societies such as The American Society of Engineering Education (ASEE created in 1893) and the National Academy of Sciences (NAS created in 1863) are prominent in the field of science education (Grayson, 1980). All these societies had the mission of promoting the development of the respective branch of the profession and also to provide means for the publication of scientific and scholarly works in professional journals. The members of these societies included faculty as well as professionals from industry.

A need for establishing a common ground for engineering programs was identified both in industry and academia. Through forums and discussions, engineering societies envisioned an independent organization to bring consistency to engineering programs. The charter mission of this new organization (eventually to become ABET; Accreditation Board of Engineering and 
Technology) was to meet industrial professional needs and academic programs quality in terms of graduates and degrees proficiency. Because industry is always evolving and adapting to change, ABET has been able to revise its criteria and guarantee consistency amongst academic programs and needs from industry.

ABET was formally established in 1935 and nowadays it is almost mandatory for an engineering degree program to be accredited by that organization for survival. Today, there are close to 2,300 accredited engineering programs in about 500 universities in the US alone. Similar accrediting practices have been established in other countries due to the global character of engineering education (Buckeridge, 2000).

ABET accreditation. Essentially, all engineering programs in the United States must be ABET accredited. To get accreditation an engineering program must participate in the ABET accreditation process. Engineering accreditation begins with a program description documentation that includes a description of the curriculum, description of facilities and labs, description of faculty members. In addition, surveys of various constituents (employers in industry, graduating students and alumni) are collected to provide an unbiased opinion on the proficiency of graduates. Also collected are surveys from graduating students about the program they have just completed. Finally and most importantly, faculty members collect evidence of student's competencies and conduct a continuous curriculum evaluation. They have to identify and document the detection of weaknesses and deficiencies as well as the measures for improvement. All this documentation is collected in a "Self Study" volume made available to ABET auditors before the site visit. The audit proceeds with a visit by ABET designated auditors, who interview the Dean, Chairmen, Faculty and students. 
One of the most important aspects of the audit is the focus on ABET Criteria for accreditation. The most current ABET accreditation process is called EC2000. This criterion is comprised of a series of very carefully worded "outcomes” that are broad and open to interpretation. In the "self study" document put together by the faculty, the assessment of each course is conducted in terms of how well or to what extent, each course addresses the various “outcomes.” An example of a relational matrix of selected courses and "outcome” relationship is given in the "Outcome-Matrix" given in Table 1 below. The specific outcomes, in ABET EC2000 (2003), that graduates must demonstrate are:

(a) An ability to apply knowledge of mathematics, science, and engineering;

(b) An ability to design and conduct experiments, as well as to analyze and interpret data;

(c) An ability to design a system, component, or process to meet desired needs;

(d) An ability to function on multidisciplinary teams;

(e) An ability to identify, to formulate, and solve engineering problems;

(f) An understanding of professional and ethical responsibility;

(g) An ability to communicate effectively;

(h) The broad education necessary to understand the impact of engineering solutions in a global and societal context;

(i) A recognition of the need for, and an ability to engage in life-long learning;

(j) A knowledge of contemporary issues;

(k) An ability to use the techniques, skills, and modern engineering tools necessary for engineering practice. (p. 5) 
Below is a selection of courses from the Mechanical Engineering Department at WVU that illustrates the contribution to the attainment of one or more outcomes from the ABET EC2000.

Table 1 Course-Outcome Matrix Sample for selected courses in Mechanical Engineering at WVU

\begin{tabular}{|l|l|l|l|l|l|l|l|l|l|l|l|}
\hline \multicolumn{1}{|r|}{ Outcome } & $\mathrm{a}$ & $\mathrm{b}$ & $\mathrm{c}$ & $\mathrm{d}$ & $\mathrm{e}$ & $\mathrm{f}$ & $\mathrm{g}$ & $\mathrm{h}$ & $\mathrm{I}$ & $\mathrm{j}$ & $\mathrm{k}$ \\
\hline $\begin{array}{l}\text { MAE244 Strength } \\
\text { \& Dynamics Lab }\end{array}$ & $\mathrm{R}$ & $\mathrm{K}$ & & & $\mathrm{R}$ & $\mathrm{K}$ & $\mathrm{K}$ & & & & $\mathrm{K}$ \\
\hline $\begin{array}{l}\text { MAE 342 } \\
\text { Dynamics of } \\
\text { Machinery }\end{array}$ & $\mathrm{R}$ & & $\mathrm{R}$ & & $\mathrm{R}$ & & $\mathrm{R}$ & & & & \\
\hline $\begin{array}{l}\text { MAE454 Machine } \\
\text { design and Mfg. }\end{array}$ & $\mathrm{R}$ & & $\mathrm{K}$ & & $\mathrm{K}$ & & $\mathrm{R}$ & & $\mathrm{K}$ & $\mathrm{K}$ & \\
\hline $\begin{array}{l}\text { MAE456 } \\
\text { CAD/FEM } \\
\text { Applications }\end{array}$ & $\mathrm{R}$ & & $\mathrm{K}$ & & $\mathrm{K}$ & & $\mathrm{K}$ & & & & $\mathrm{K}$ \\
\hline $\begin{array}{l}\text { MAE 471 Princ. } \\
\text { Of Eng. Design }\end{array}$ & $\mathrm{R}$ & $\mathrm{R}$ & $\mathrm{K}$ & $\mathrm{K}$ & $\mathrm{R}$ & $\mathrm{K}$ & $\mathrm{K}$ & $\mathrm{K}$ & $\mathrm{K}$ & $\mathrm{K}$ & $\mathrm{K}$ \\
\hline $\begin{array}{l}\text { R - related course that supports this outcome but is not a "key" course for the corresponding } \\
\text { outcome } \\
\text { K- designates a course to be a "key" course to support a specific outcome }\end{array}$ & \\
\hline
\end{tabular}

Information compiled by author from the MAE department of WVU

Each course listed in the matrix above (this applies to all the courses in the curriculum) complies and contributes to the attainment of one or more outcomes to some extent, specifically those outcomes for which the course is designated as a "key" contributor. Faculty members are obliged to make that assessment and ABET auditors review and verify the adequateness of such assessment. The way faculty members conduct the Department's self-assessment every year is as follows:

1. Instructor of course MAEXXX collects evidence of student work (copies of assignments, reports, exams, quizzes of various students) during the entire duration of the course. 
2. Instructor prepares a file (portfolio) with syllabus, handouts, and copies of student's work.

3. An ABET assessment team comprised by two other faculty in the Department review the file to assign a score, from lowest (1) to highest (5) for each "Goal” of each outcome.

4. Recommendations are issued and discussed in a yearly faculty meeting.

5. Corrective measures are taken through Curriculum Committee and implemented by instructors subsequently.

In addition to the assessment, an accreditation committee is charged with conducting and collecting surveys from graduating students, alumni, employers and advisory committees. This information is collected and organized in a volume called the "Self Study Report" that is submitted to ABET reviewers before the ABET Audit.

During the audit, external reviewers designated by ABET visit the department and conduct individual interviews with students, faculty and administrative personnel. They tour the facilities and have full access to the files of each course and the documentation relative to the self assessment process.

After the review by ABET a diagnostic and recommendation for accreditation are issued, which varies depending on the state of the program under review. If the minimum criteria are satisfied and no major weaknesses or deficiencies are detected, ABET auditors recommend a 6year certification. In some cases it may be conditional with recommendation for corrective actions or further documentation of specific activities or information. In some cases, corrective actions are recommended and certification is extended for a probationary 3-year period, at which time a full ABET audit must be conducted again. In general for any accredited program, this 
indicates major weaknesses or deficiencies in the program that require drastic corrective measures and for the most part, investment in facilities, personnel or leadership.

The impact of ABET on engineering education is a subject of continuous evaluation and discussion by professional organizations, such as the American Society of Engineering Education (ASEE), the National Science Foundation (NSF) and the National Academy of Engineering (NAE), to name a few. Many professional engineering organizations are now interested in understanding the results and above whole the feedback of the effect of ABET EC2000 Criteria on the students’ learning outcomes.

\section{Engineering Accreditation Criteria EC2000 and Outcome h.}

Process and awareness skills. The reasons for changes in engineering curriculum can be found in the discrepancy between the needs of industry and the students' academic preparation (Volkwein, Lattuca, Terenzini, Strauss \& Sukhbaatar, 2004). Employers need engineers ready to work effectively in a different and changing work environment. The Accreditation Board of Engineering Education (ABET) and its Accreditation Process Review Committee (APRC) have introduced flexibility in their own accreditation criteria in order to promote innovation in engineering curriculum to better respond to future challenges (Lattuca, Terenzini \& Volkwein, 2006 ). It is believed that changes in the accreditation reform are going to bring changes in student learning outcomes. For this, the new accreditation criteria, EC2000, stresses a set of five "hard” engineering skills and six "professional” skills which are comprised in the new set of eleven outcomes (Criterion 3.a-k.). Shuman, Besterfield-Sacre, and McGourty (2005) categorize the first set as process skills and the second set as awareness skills. With process skills, students are learning the intellectual techniques to understand how each component of a discipline fits 
together. Awareness skills are useful to understand the local and the global relationship in their future problem solving activities (Shuman et al., 2005). Hard skills include:

- $\quad$ an ability to apply knowledge of mathematics, science, and engineering (3.a);

- $\quad$ an ability to design and conduct experiments, as well as to analyze and interpret data (3.b);

- $\quad$ an ability to design a system, component, or process to meet desired needs within realistic constraints such economic, environmental, social, political, ethical, health and safety, manufacturability, and sustainability (3.c);

- $\quad$ an ability to identify, formulate, and solve engineering problems (3.e); and

- $\quad$ an ability to use the techniques, skills, and modern engineering tools necessary for engineering practice (3.k). (p. 41)

In the second set of skills, the most important changes can be found on social and environmental subject matters. The emphasis on skills called "soft” as opposed to "hard” skills traditionally taught in engineering are giving a new dimension to the curriculum that is revolutionizing the philosophy of education concerning engineering (Shuman et al., 2005). These skills include:

- $\quad$ an ability to function on multi-disciplinary teams (3.d);

- $\quad$ an understanding of professional and ethical responsibility (3.f);

- $\quad$ an ability to communicate effectively (3.g);

- the broad education necessary to understand the impact of engineering solutions in a global, economic, environmental, and societal context (3.h);

- $\quad$ a recognition of the need for, and an ability to engage in lifelong learning (3.i); and 
- a knowledge of contemporary issues (3.j). (p. 41)

Resistance to teach "soft skills."The problems posed by these "soft skills" are many, but from an academic point of view it is difficult to teach and later evaluate skills that are not considered rigorous and significant for the development of an engineering program/education. Faculty in engineering are not trained in those subject matters and therefore the implementation of skills derogatorily called "soft” is difficult to perform (Grose, 2004). Evidently, some resistance due to this radical shift in paradigm is to be expected. Splitt (2003) remarked that changes are always difficult, especially for organizations like universities whose performances are viewed by the engineering community as "successful” (p.30). Effectively, students in engineering are well prepared for mathematic application and theoretical study, but employers complained that they lack professional skills necessary for success in the workplace such as those covered by the "soft skills" (Lattuca, Terenzini, Wolkwein , and Peterson, 2006). In parallel, Splitt (2003) pinpoints that barriers to the engineering education reform may be found in the mismatch between the skills necessary for an academic career and the practice of engineering in industry. Latucca et al. (2006) remarked that practical experience in industry is not a prerequisite for hiring engineering faculty members, the result being that very few have it. In conclusion, engineering faculty are probably not the best to teach the newly defined skills that are required by industry because their academic culture assesses and rewards research and publication, and not innovative skill-building approaches or extra-technical talents (Rugarcia, 2000). In defense, the engineering community expressed concern about the difficulties to make changes due to the rigidity inherent of EC2000 (Lattuca et al., 2006).

Meanwhile, ABET's efforts, through a variety of organizations and methods, where ideas are developed and disseminated, continue to shape the academic/scientific community's 
view in order to move toward the desired direction. However, two major incentives are instrumental in orienting reluctant faculty to the application of the new paradigm; 1 ) engineering schools' accreditation is linked to the implementation and assessment of the outcomes and, 2) the funding of research is linked to commercial interests which are lobbying for changes and determining the knowledge to be developed.

In order to respond to these challenges, Colleges of engineering are innovating in teaching methodologies which create synergy among faculty. This has been recently assessed by the Penn State University through the program Impact of EC2000 (2007). The National Science Foundation (NSF) that funded the programs and wanted to have a real and vivid snapshot of the impact of the newly implemented accreditation standards.

On the impact of EC2000. In 2002, the Center for the Study of Higher Education at the Pennsylvania State University designed a study on the impact of EC2000. The study took threeyears to complete and in March of 2006, an executive summary was published. The objective of Engineering Change: A Study of the Impact of EC2000 (Latucca et al., 2006) was to evaluate the impact of the new learning outcomes on the engineering graduates. Two questions were at the center of the study:

1. What impact, if any, has EC2000 had on student learning outcomes in ABET-accredited programs and institutions?

2. What impact, if any, has EC2000 had on organizational and educational policies and practices that may have led to improved student learning outcomes? (p. 1).

The focus of the researchers conducting the study was to find evidence of improvements due to the implementation of EC2000 standards. A conceptual framework (see Figure 2)_was 
designed to identify the programs changes, student experiences and desired outcomes. The goal was to compare the preparation of students before and after EC2000 guidelines based on the 11 learning outcomes specified in criterion 3. For that, surveys were sent to faculty members, programs chairs, deans, students and employers at 40 colleges of engineering. Information was gathered from 200 engineering programs and statistically analyzed for evidence of changes.

Below is the conceptual framework utilized for the Engineering Change Study at The Pennsylvania State University.

\section{Engineering Change: Studying the Impact of EC2000}

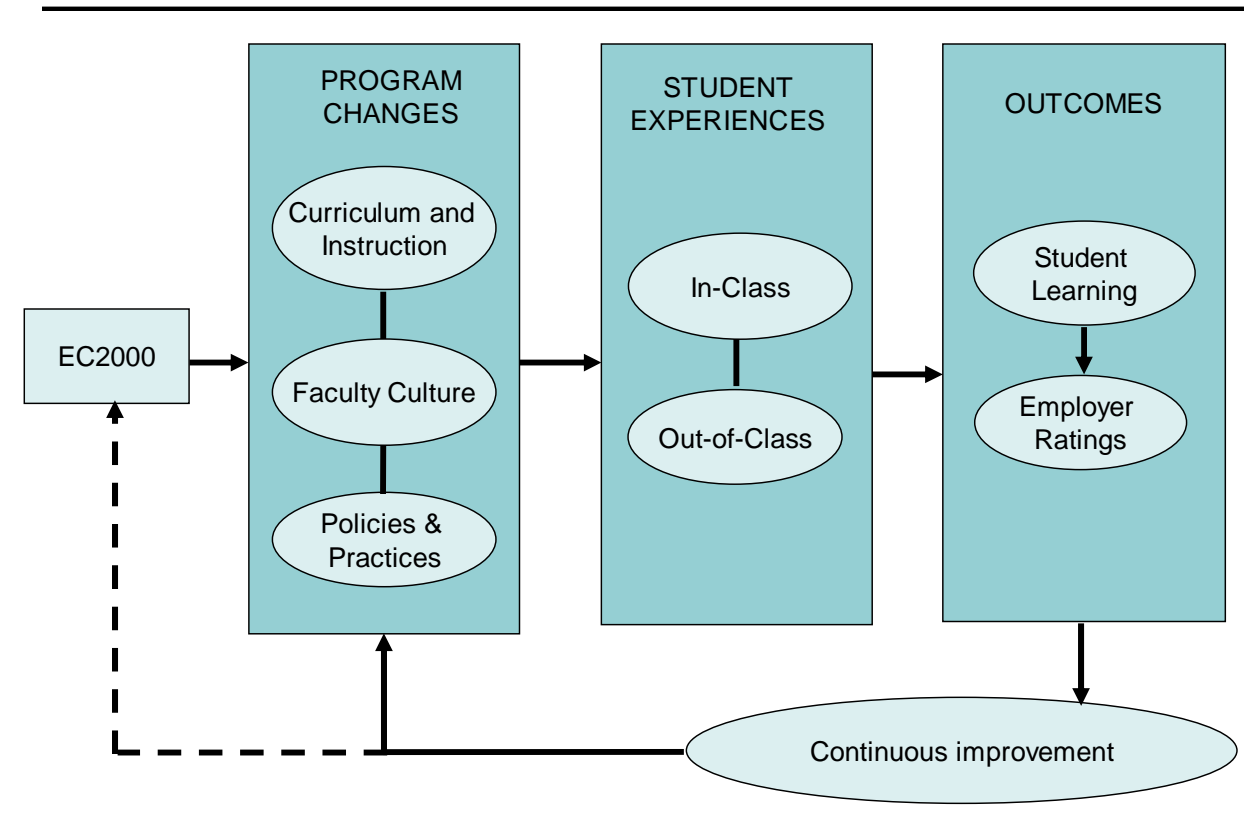

Figure 2. Conceptual Framework for the Engineering Change Study. (Lattuca et al., 2006)

The findings from the study are multiple and summarized as follows:

1. Chairs and Faculty's point of view or opinion on the changes; 
The survey's results reported that most of the 11 outcomes were given increased attention and also that active learning was substantially improved by 75 percent compared to that of a decade before (p. 5).

As for faculty culture, significant improvement was noted in the assessment of students' learning. The knowledge gained from the data is used as feedback to improve the quality of the program.

2. Students’ point of view:

Students' survey reported a small change between the 2004 graduates and the mid-1990’s ones. However, more active involvement both from students and faculty was reported. The findings indicate that the most significant outcome difference between the graduates is the societal and global issues awareness (Outcome h). Other outcomes such as applying engineering skills (outcome k), group skill (outcome d), and ethic awareness (outcome f) are following in decreasing importance.

3. Employers' point of view:

Employers are still convinced of the necessity of improving the implementation of the 11 professional skills. They rate most of the 11 outcomes as highly important or essential; however, two outcomes are considered the least important: Outcome h (engineering in global and social contexts) and outcome j (knowledge of contemporary issues) (p. 11).

It is interesting to note that Outcome $\mathrm{h}$ is the outcome considered the least important for employers, but is one of the most prominent differences for graduates after the application of EC2000. The difference of opinion is important to notice, knowing how significant the impact of 
industry and EC2000 has on faculty and curricula. Below is the Figure illustrating the national results from graduates before and after ABET EC2000.

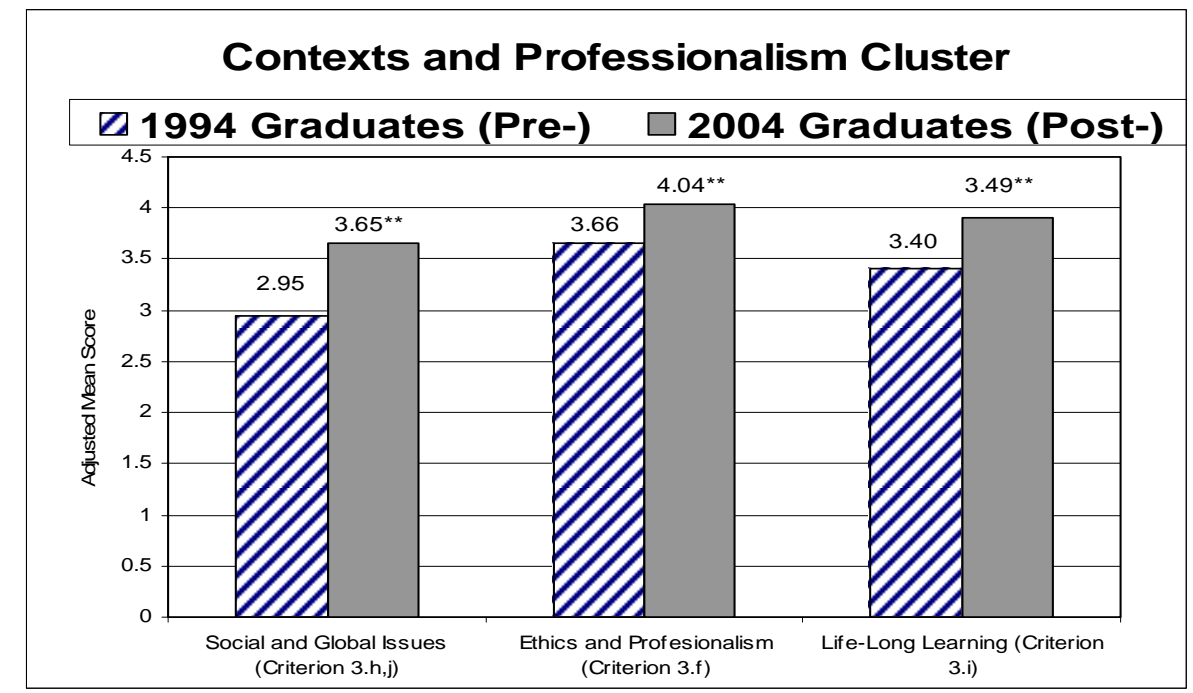

** $p<0.001$

Figure 3. Different Results between engineering graduate cohorts on outcomes h, j, f and i. (Lattuca et al., 2006)

Another study by the same group of researchers, using the data collected in the national study of EC2000, was focused in understanding whether the needs of industry were adequately met by the academic community. Getting in Sync: Faculty and Employer Perceptions from the National Study of EC2000 (2006) is particularly aimed at establishing evidences of changes in the curriculum in order to comply with the industry's desires. The results demonstrate that employers (business leaders) are satisfied by the current state of engineering education for the implementation of "hard”/technical skills, but they still recognize that improvements need to be done on the "soft” learning outcomes. Program chairs and faculty surveys' results indicate that the greatest changes in instructional practices were directed to satisfy the need of soft outcomes and that little change was made to satisfy hard outcomes. The changes in curriculum and the 
perceived results by industry are not in total agreement, but the overall effect is positive for both parties.

The difficulty of interpreting results resides in the fact that universities are well structured environments and consistent in their objectives, whereas industries have different structures with different objectives, which is to produce goods or services of consumption. The communication between the two environments is indispensable but the results need to be wisely studied and analyzed. On the other hand, it is difficult to know if industries (or companies) have enough information about their own environments and whether they have documented the short and long term needs in their workforce.

It is also important to note that a “customer-supplier” relationship between industry and academy must exist, in which the link product is the engineering graduate. While industry understands very well the importance of a “customer-supplier” relationship, the connection between industry and academy is still elusive.

In Getting in sync: the impact of accreditation on student experiences and learning outcome (2006), the research focuses on the assessment of student outcomes between 1994 and 2004. The results have implications for the credibility of accreditation processes for educators and higher education agencies pushing the agenda for change. In the end, the quality of the academic program is measured by its conformity to the criteria required by EC2000. The study's findings show that student experiences and outcomes have changed, and suggest the positive impact of EC2000 on educational differences (Volkwein et al., 2006).

The specific changes in students' experiences are reported as follows:

- More collaborative and active engagement in their own learning; 
- More interaction with instructors;

- More instructor feedback on their work;

- More participation in cooperative education and internship experiences;

- More involvement in engineering design competitions;

- More involvement in professional society chapters, and

- More emphasis in their programs on openness to new ideas and people. (p.11)

The students' self reflective gain on the 11 learning outcomes has already been reported previously in this document. The findings show a significant gain in all 11 outcomes but a discrepancy between employers and students on Outcome h $(\mathrm{OH})$.

Curriculum innovation and Outcome h. Although faculty members have changed their instructional techniques and adopted new approaches (or revised syllabi and curriculum) in their teaching to comply with EC2000, we know very little about how educators teach the new professional skills (Felder, 2003). At the individual level, each engineering faculty member is solely responsible for the new curricula and pedagogical methods utilized in his/her class. Assessment is made later, based on the tools/surveys or documentation prepared by the faculty. The difficulty with EC2000 is to understand how these non-technical skills can be better taught, the goal being to better prepare students for a changing world. This represents additional workload for faculty who are not particularly inclined to change their ways of teaching (Rugarcia et. al., 2000). Nonetheless, the traditional dominant educational method such as lecture is no longer considered efficient technique to address the new skills. In spite of that, one of the main obstacles facing the implementation of the alluded competencies is not so much the traditional approach to teaching than the time constraint for graduation. Four years to graduate is not enough for the quantity of knowledge that needs to be absorbed by the students. The modern 
engineers need to be well prepared in the fundamentals of engineering but with the rapid changes in society, it is almost impossible to teach everything they need to know when they go to work (Rugarcia et. al., 2000). Knowledge becomes quickly obsolete and specialization in particular areas becomes rapidly non-usable. It is, thus, important to teach skills and competencies that will help to reach the educational objectives of engineering education. New educational methods and curriculum design are part of the solution proposed by various professional societies (ASEE, ASME, ASEE, ASCE etc). The Foundation Coalition gives the definitions based on Bloom's taxonomy about the attributes for Outcome h. (see Appendix B). Another argument for the application of new educational methods is that the capacity to embrace change in the curriculum is seen as a proof of quality of education imparted by the academic program department. For the National Science Foundation (1995) these quality changes include: “improved pedagogy, revised curricula content, and a process of continuous assessment and continuous improvement” (p.8).

The Foundation Coalition (FC), one of the Engineering Education Coalitions, has made available on its web site some teaching techniques for engineering faculty to use in their class in order to comply with the program outcomes. These instructional methods known as Active or Cooperative Learning (ACL) are techniques that consist of actively involving the students into their learning experiences by reading, writing, discussing and being engaged into problem solving (Bonwell \& Eison, 1991). The Figure below illustrates the different degrees of retention and involvement corresponding to the techniques used. 


\section{CONE OF LEARNING}

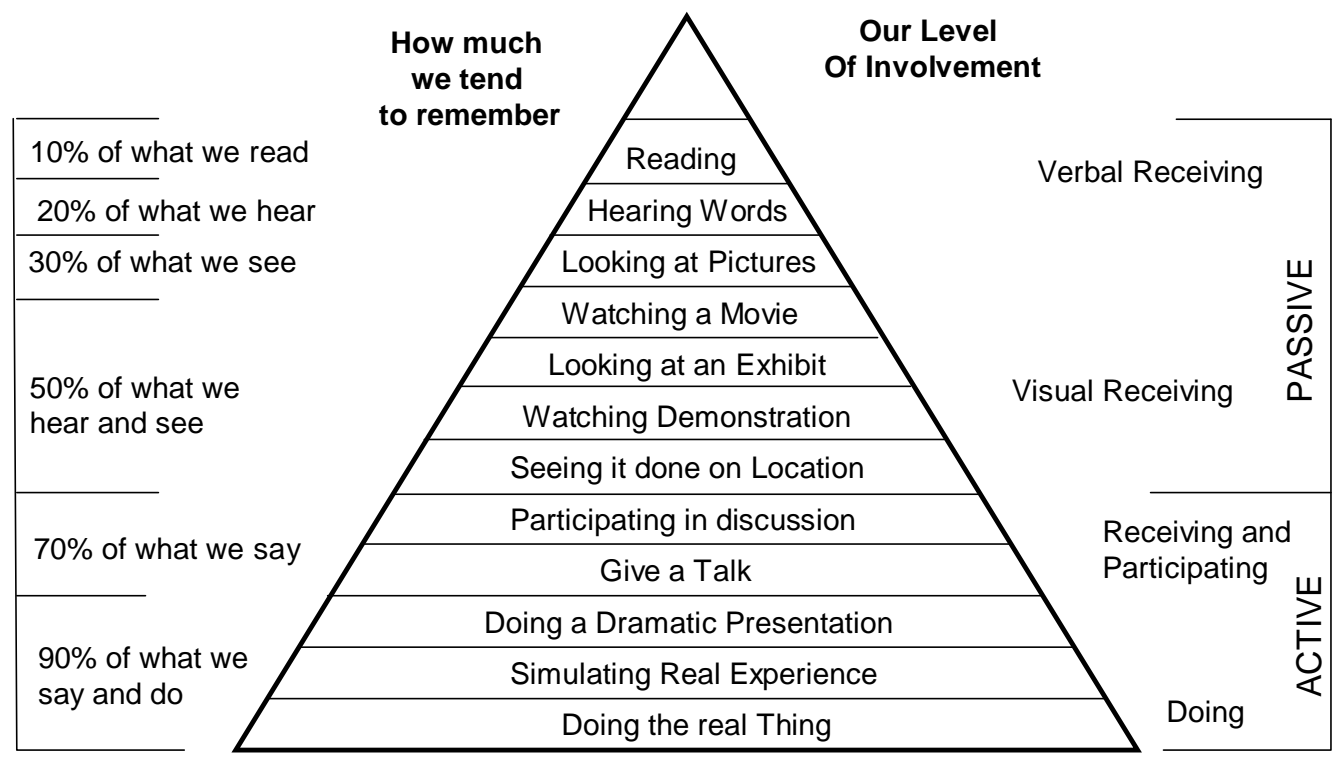

Figure 4. Cone of Active Learning. (FC, http:/www.foundationcoalition.org)

Furthermore, FC encourages engineering curricula to accommodate students with various learning styles. It provides intellectual tools such as the "Bloom taxonomy” theory and the Perry's model to evaluate and enhance the efficiency of teaching methodologies.

Bloom’s Taxonomy of Cognitive Domain recognizes six levels of learning. Each level is based on the previous one and represents a higher hierarchical complex mental ability processes. The lowest level is called knowledge the next up are comprehension, application, analysis, synthesis and evaluation (Bloom, 1956).

Perry’s model (1968) allows the evaluation of the dependent, independent, interdependent learning style of students and permits tracing the shift undergone by students from one level to another, level nine being the highest score. The goal is that students should reach the "self-learning” stage to become independent thinking subjects to be able to function in a team. 
In other words, the changes in the curriculum should provide practical experiences where the students learn by doing as an important component to engineering education. Other techniques such as problem-based learning (PBL) and project-organized learning (POL) are useful approaches to further enhance student practical learning.

Moreover, The National Science Foundation (1995) edited a number of effective pedagogical approaches that characterize the effectiveness of these methods, these approaches are:

- active learning; collaborative learning; modular learning;

- $\quad$ research, development and practice experience for undergraduates;

- $\quad$ new physical environments;

- distance learning;

- $\quad$ hands-on learning; and

- integrative learning. (p. 12)

In summary, students are expected to be active learners and creative people who not only know but understand more than the nuts and bolts of engineering. Once something is understood it can be re-utilized in a much more creative way and in turn prepare people to innovate and be the leaders in the $21^{\text {st }}$ century.

The shift of focus from knowledge to skills acquisition emphasizes the improvement of students' capability for self-learning (NSF, 1995). Cheong (1999) believes that the number of courses in engineering programs could be reduced if students learn how to think, analyze and synthesize information since knowledge is available from the information and telecommunications infrastructures (computing information technology). In other words, students need to develop intellectual qualities such as problem-solving skills, self-reliance, and creativity. Many proponents emphasize holistic education as a possible solution posed by the 
increasing multi-disciplinary nature of today’s engineering problems (Grasso \& Martinelli, 2007; NSF, 1995). In order to avoid engineers becoming a commodity and outsourced resource, engineers need to be given a broader education where "engineering schools focus on teaching students how to think like engineers” (Grasso et al., p. B9). They also add that the United States engineering education needs to bring additional value to their practice in order to maintain the employability of their students in a global marketplace (NAE, 2005; Bordogna, 1997; Jones, 2003). However, the shortage of engineers produced by universities in the United States is a situation that could have serious consequences for the economy. According to Friedman (2006), the United States is not educating enough engineers to sustain the level of inventiveness necessary for national competitiveness. If nothing is done to regenerate the engineers labor force (the baby boom generation) by improving the number of students interested in sciences and engineering careers, the United States of America will loose its “preeminence to other areas of the world" (p.331).

Outcome $h$ and international experience. Redesigning courses for integration of new content rather than adding new information is the task given to faculty in order for students to master the required knowledge and skills. According to Lattuca et al. (2006) Outcome h, is one of the skills that has not received systematic attention. It is probably one of the most difficult to resolve since most of international activities existing are there because of individual faculty interested in the field. International exchange programs are usually the results of personal faculty members' connection with a foreign institution and consequently prone to disappear with the faculty’s disinterest in overseas experience (Shuman et al., 2005; Mestenhausser \& Ellingboe, 1998). Data from a Carnegie survey (1991) shows that American faculty, compared to other 
professors in other countries, are the least involved in international activities in general (Altbach, 1998).

However, the market for engineers with international competencies has grown tremendously not only in the United States, but also in other parts of the world, making individuals with these skills particularly marketable. Engineering is naturally a field with an international potential because of its inherently global nature. In consequence, it seems natural that engineers should be prepared for international careers in a world that demands increased mobility for professionals with the ability to work in a borderless economy.

International education is an asset in resolving the challenge posed by Outcome h; however, courses created specifically to respond to Outcome h are almost non-existent in engineering departments across the country. There are, however, some programs especially created in engineering such as the one at the University of Rhode Island, which offers a joint program between Germany and the United States. Dartmouth University, the University of Delaware, the US Air Force Academy, Purdue University, and lately Penn State have created programs where foreign languages requirement courses and work experience in a foreign country are part of the degree completion (Jones \& Oberst, 2003).

On the other hand, national organizations such as the International Student Exchange Program (ISEP) and the International Association for the Exchange of Students for Technical Experience (IAESTE/AIPT) offer respectively a semester abroad and an overseas job experience for students interested in overseas academic experiences. Among these national programs there is one specifically oriented towards the needs of engineers; the Engineering Program for International Careers (EPIC), that offers international options for engineering curriculum. (Ollis, 1999). 
Other experiences are the fruits of a creative vision of some faculty, departments, colleges, or institutions. A program created at West Virginia University, teams up Mexican and U.S. students to work on real industrial projects under the guidance of U.S and Mexican faculty in Queretaro, Mexico. The outreach experience is finalized by a professional presentation where results are given in both languages (US students in Spanish and Mexican students in English) by the students to the industry's engineers. According to Ollis (1999), the West Virginia program (Industrial Outreach Program in Mexico) “addresses virtually every one of the ABET/EC 2000 criteria” (p. 9).

Jones (1995) mentions various barriers to the creation of international opportunities for engineers. Whereas overseas universities are teaching some of their classes in English, American faculty have been slow to prepare their students for international practice. He explains this situation as follows:

1) Lack of functional proficiency in a language other than English prevents students from taking advantage of many excellent study and work opportunities overseas.

2) The engineering curriculum is still impervious to the demands of all but the need for increased technical competence.

3) US faculty, including engineering faculty, are not in a position to become strong advocates for international preparation of their students since they themselves do , not demonstrate much professional interest in the world outside the US.

4) Scholarship money for students wanting to Study Abroad is still lacking. (p. 5)

Because globalization has such an impact of the life of engineers, higher education institutions need to address theses issues by broadening engineering education. Young American students need to be equipped with the qualifications to work for global firms and hold positions 
of leadership. The responsibility for university is not only to be a learning place but also a center for global awareness. Jones (1995) includes various recommendations to correct this situation. He advises the following in engineering programs:

1. Development of foreign language proficiency, cultural background understanding, international business concepts, and international technical practices in an integrated and comprehensive manner.

2. Opportunities for intensive foreign language/culture Study Abroad in countries using the particular language studied, encouraged by advisors.

3. Work internship periods abroad utilizing language and cultural understanding already developed through academic programs.

4. Engineering faculty members to develop international expertise and opportunities for visits and exchanges abroad.

5. Support by funding agencies for pilot programs supplemented by meetings of professional societies for review of results and promotion of successful approaches. (p. 6)

Ollis (1999), one of the key participants on the SUCCEED coalition that particularly emphasizes the international aspect of engineering education, calls for the extension of overseas practice in engineering education. He believes that American engineers need to gain knowledge of science and engineering practices by working in other countries. The experience develops communication and cooperation as well as improving language and cultural skills. He argues that international study and practice address "five of the thirteen ABET/EC 2000 criteria for US engineering graduates” and that through “outside practice opportunities” students are better prepared than through academic courses (p.3). 
The five ABET skills mentioned by Ollis are:

1. Outcome f; an understanding of professional and ethical responsibility,

2. Outcome g; an ability to communicate effectively,

3. Outcome h; an ability to understand the impact of engineering solutions in a global and societal context,

4. Outcome j; knowledge of contemporary issues and,

5. Outcome k; the ability to use techniques, skills and modern engineering tools for engineering practice. (p. 3)

\section{Summary}

There is no unanimity on what constitutes an adequate response to the challenge posed by Outcome $\mathrm{h}$ in engineering. The difficulty comes, in part, from the conceptual confusion about the meaning of international education for engineers and global awareness. Questions about the degree or nature of global and social exposure, about the significance of international education from the different educational stakeholders are still under debate.

This dissertation aims at establishing "best practices" in terms of satisfying Outcome $h$ requirements for accreditation by engineering departments. An analysis will be conducted to determine the impact of how engineering programs comply with accreditation requirement (specifically EC 2000 Outcome h) and the impact on global competencies expected of engineering graduates. 
Chapter Three

Research Methodology

\section{Statement of Problem}

The problem consisted in assessing the effectiveness of the approach used by engineering departments to satisfy the requirements of Outcome h of the ABET accreditation criteria in terms of Global Competency Attention (GCA) and Global Competency Performance (GCP). Engineering departments typically choose one of three approaches for this purpose: a) using selected humanities and social sciences courses; b) adding topics to current engineering courses to address Outcome h requirements and c) conducting Study Abroad courses in engineering. Different approaches require different levels of effort (GCA) and yield different levels of effectiveness (GCP). The problem in this research was to assess the effectiveness of these approaches in terms of Global Competencies.

An electronic questionnaire was sent to engineering chairs from the Southern Regional Education Board (SREB) group that comprises 28 universities. A statistical analysis of the survey responses was divided in three parts: 1) organizing the data for analysis 2) describing the data, and 3) testing hypotheses.

Data was gathered, classified and summarized to provide information about the sample and the measures. Descriptive statistics analysis consisted of the usual analytical procedures including frequency distribution, means and standard deviations together with simple graphic analysis. 
In the following section, inferential statistics were used for each research question, to examine relationship between the response variables and the different groups under study, and between independent and dependent variables.

\section{Research Question One}

a. Is there a significant difference in the attention afforded to Global Competencies Attention (reflected by GCA scores) when comparing engineering departments who primarily use either selected Humanities and Social Sciences courses to satisfy Outcome h, as opposed to adding topics to current engineering courses or by conducting Study Abroad programs in engineering?

i. Null Hypothesis: There is no significant difference in the attention afforded to Global Competencies Attention (reflected by GCA scores) when comparing engineering departments who primarily use either selected Humanities and Social Sciences courses to satisfy Outcome h, as opposed to adding topics to current engineering courses or by conducting Study Abroad programs in engineering.

ii. Alternative Hypothesis: There is a significant difference in the attention afforded to Global Competencies Attention (reflected by GCA scores) when comparing engineering departments who primarily use either selected Humanities and Social Sciences courses to satisfy Outcome h, as opposed to adding topics to current engineering courses or by conducting Study Abroad programs in engineering. 
b. Variables

i. Independent variables or explanatory variables

1. Three groups were established based on the approach used by the departments to deal with Outcome h, which corresponded to questionnaire item \# 13 (How is your Department (PRIMARILY) preparing engineering students to develop global competencies? (Please, select ONLY one). The groups were:

1. Using selected Humanities and Social Sciences courses.

2. Adding topics to current engineering courses.

3. Conducting Study Abroad programs in engineering.

ii. Dependent variable or response variable

1. The item from the survey used to determine the dependent variable was called Global Competency Attention (GCA) and was to be found in questionnaire item \# 2 (How well are these global competencies addressed in the curriculum of your program?). GCA represented the Attention afforded to Global Competencies by the departments. 
c. Statistical Analysis

i. One-Factor Independent Measures ANOVA

1. An Analysis of variance (ANOVA) was performed to test the null hypothesis based on the different approaches to satisfy Outcome h. (These groups have already been mentioned in the previous section).

If the result of the ANOVA suggested an inequality between group's means which meant that the null hypothesis was rejected, then a multiple comparison procedure was used to determine which means was different from the others. After-the-fact test or Post Hoc comparison such as Bonferroni procedure was performed to keep Type I error in check. A type I error is defined as incorrectly rejecting the null hypothesis when in fact the null hypothesis is true. However, reducing Type I error increases Type II error.

2. For Research Question One and Research Question Two, alpha was split three ways.

\section{d. Additional Data}

i. Although such data were used as part of the null hypothesis testing reflected in the research question, the survey included other items (table below) that helped describe in a richer qualitative context this research question. Responses to these items were examined descriptively in the findings. 
Research Question One, including additional items for descriptive statistics

\begin{tabular}{|c|c|c|}
\hline Research Question & $\begin{array}{l}\text { Questionnaire questions related to } \\
\text { this construct }\end{array}$ & Analysis method \\
\hline $\begin{array}{l}\text { Is there a significant difference } \\
\text { in Global Competency Attention } \\
\text { (GCA) scores when comparing } \\
\text { engineering departments who } \\
\text { primarily use either a) selected } \\
\text { Humanities and Social Sciences } \\
\text { courses, b) Adding topics to } \\
\text { current engineering courses or c) } \\
\text { Study Abroad programs in } \\
\text { engineering to comply with } \\
\text { Outcome h requirements? }\end{array}$ & $\begin{array}{l}\# 1,2,9,11 \\
13,14,15,16,17\end{array}$ & $\begin{array}{l}\text { Analysis of Variance } \\
\text { ANOVA } \\
3 \text { groups (\# 13) } \\
\text { With response variables } \\
\text { GCA (\#2) }\end{array}$ \\
\hline
\end{tabular}

\section{Research Question Two}

a. Is there a significant difference in Global Competency Performance (GCP) scores when comparing engineering departments who primarily use either selected Humanities and Social Sciences courses to satisfy Outcome h, as opposed to adding topics to current engineering courses or by conducting Study Abroad programs in engineering?

i. Null Hypothesis: There is no significant difference in Global Competency Performance (GCP) scores when comparing engineering departments who primarily use either selected Humanities and Social Sciences courses to satisfy Outcome h, as opposed to adding topics to current engineering courses or by conducting Study Abroad programs in engineering. 
ii. Alternative Hypothesis: There is a significant difference in Global Competency Performance (GCP) scores when comparing engineering departments who primarily use either selected Humanities and Social Sciences courses to satisfy Outcome h, as opposed to adding topics to current engineering courses or by conducting Study Abroad programs in engineering.

b. Variables

i. Independent variables or explanatory variables

1. Three groups were established based on the approach used by the departments to deal with Outcome h, which corresponded to questionnaire item \# 13 (How are your Department (PRIMARILY) preparing engineering students to develop global competencies? (Please, select ONLY one). The groups were:

1. Using selected Humanities and Social Sciences courses.

2. Adding topics to current engineering courses.

3. Conducting Study Abroad programs in engineering.

ii. Dependent variable or response variable

1. The item from the survey used to determine the dependent variable was called Global Competency Performance (GCP) and was to be found in questionnaire item \# 6 (How well have your graduates acquired these 
global competencies AFTER EC2000? GCP represented the effectiveness (or attainment) of Global Competencies by students as required by Outcome h.

c. Statistical Analysis

i. One-Factor Independent Measures ANOVA

1. An Analysis of variance (ANOVA) was performed to test the null hypothesis based on the different approaches to satisfy Outcome h; these groups have already been mentioned in the previous section. If the result of the ANOVA suggested an inequality between group's means that resulted in rejecting the null hypothesis, then a multiple comparison procedure was used to determine which means was different from the others. After-the-fact test or Post Hoc comparison such as Bonferroni procedure was performed to keep Type I error in check. A type I error is defined as incorrectly rejecting the null hypothesis when in fact the null hypothesis is true. However, reducing Type I error increases Type II error.

2. For Research Questions One and Two, alpha=.05 was split 3 ways to reduce Type I error. Keeping the alpha value small allowed reducing the probability of rejecting a null hypothesis when in fact there was no difference between group’s means. 


\section{d. Additional Data}

i. Although such data were not used as part of the null hypothesis testing reflected in the research question, the survey included other items (table below) that helped describe in a richer qualitative context this research question. Responses to these items were examined descriptively in the findings.

Research Question Two, including additional items for descriptive statistics

\begin{tabular}{|l|l|l|}
\hline Research Question & $\begin{array}{l}\text { Questionnaire } \\
\text { questions related to this } \\
\text { construct }\end{array}$ & Analysis method \\
\hline $\begin{array}{l}\text { Is there a significant difference in } \\
\text { Global Competency Performance }\end{array}$ & $\# 1,6,9,10,12$, & $\begin{array}{l}\text { Analysis of Variance ANOVA } \\
\text { 3 groups (\# 13) } \\
\text { GCP scores when comparing } \\
\text { engineering departments who } \\
\text { primarily use either a) selected } \\
\text { Humanities and Social Sciences } \\
\text { courses, b) Adding topics to } \\
\text { current engineering courses or c) } \\
\text { Study Abroad programs in } \\
\text { engineering to comply with }\end{array}$ \\
Outcome h requirements? & & GCP (\#6) \\
\hline
\end{tabular}

\section{Research Question Three}

a. Can we predict, in a statistically significant fashion, using regression analysis, an engineering departments GCP scores from their respective GCA scores?

i. Null Hypothesis: There is no statistically significant regression analysis for predicting engineering departments GCP scores from GCA scores. 
ii. Alternative Hypothesis: There is a statistically significant regression analysis for predicting engineering departments GCP scores from GCA scores.

b. Variables

i. Independent

1. Item from the survey used for Research Question Three was the independent variable called Global Competency Attention (GCA) which corresponded to questionnaire item \# 2 (How well are these global competencies addressed in the curriculum of your program?)

ii. Dependent

1. The Global Competency Performance (GCP) was the dependent variable and corresponded to questionnaire item \# 6 (How well have your graduates acquired these competencies AFTER EC 2000?).

\section{c. Statistical Analysis}

i. Regression Analysis

1. A regression analysis ("least squares curve fitting”) was performed to predict the relationship between the dependent variable Global Competency Performance (GCP) and the independent variable Global Competency Attention (GCA).

2. For research question 3 , alpha $=.05$ 


\section{d. Additional Data}

i. Although such data were not used as part of the null hypothesis testing reflected in the research question, the survey included other items (table below) that helped describe in a richer qualitative context this research question. Responses to these items were examined descriptively in the findings.

Research Question Three, including additional items for descriptive statistics

\begin{tabular}{|l|l|l|}
\hline Research Question & $\begin{array}{l}\text { Questionnaire } \\
\text { questions related to this } \\
\text { construct }\end{array}$ & Analysis method \\
\hline $\begin{array}{l}\text { Can we predict, in a statistically } \\
\text { significant fashion using } \\
\text { regression analysis, an } \\
\text { engineering department's GCP } \\
\text { scores from their respective } \\
\text { GCA scores? }\end{array}$ & \# 3,4,5,6,7,8 & $\begin{array}{l}\text { Regression Analysis } \\
\text { Independent variable GCA } \\
(\# 2)\end{array}$ \\
\hline
\end{tabular}

\section{Population and Sample}

ABET Outcomes are about the same for all engineering fields; every department of engineering can voluntarily comply with the standard of EC2000 in order to obtain Accreditation. According to ABET statistical data available (http://www.abet.org/accrediteac.asp) there are over 2300 accredited engineering programs at some 500 institutions in the U.S.A. The population studied consisted of undergraduate engineering accredited programs covering but not limited to any of the following engineering disciplines: chemical, civil, electrical, mechanical, aerospace, computer, industrial, mining, textile, petroleum engineering, etc. 
In this particular research, only undergraduate engineering programs from the Southern Regional Education Board (SREB) universities/institutions with an ABET accredited engineering program were studied. The SREB consists of 28 public, four-year institutions of higher education in the Southern Regional Education Board area. These 28 universities constitute the peer group with which West Virginia is associated. These universities belong to the SREB's institutional categories of universities conferring 100 Ph.D degrees annually.

An electronic questionnaire was sent to each engineering department of each university of the SREB group (Appendix C). Considering that each university had at least 5 departments (mechanical, electrical, civil, industrial and chemical), with several universities having more programs like mining, textile, petroleum, etc., 39 responses for 130 departments which represented about 30\% return was considered a reasonable response rate, at the same time it was expected that every effort would be made to increase the return. In the case of research questions \# 3, for which regression analysis was used, the response rate was expected to be around $58[n=(50+8) * m(m=\#$ of IV)], the independent variable being global competency attention (GCA). On the other hand, some limitations were expressed due to the possibility of a low sample size.

\section{Survey Instrument}

Description of survey. A questionnaire was sent electronically to chairs of undergraduate engineering disciplines as mentioned previously. The research instrument consisted of 5 numerical questions, 16 ordinal questions and 7 nominal questions with one final open-ended question for a total of 29 questions. The open-ended question provided a place where respondents could write their observations or suggestions. Ten out of the 16 ordinal questions had three descriptors as it is used in the Likert response scale questionnaire format, the remaining questions used a scale of four descriptors from 1 to 4 . 
To answer the questionnaire entirely only took a brief time (between 10 to 15 minutes approximately). A cover letter encouraging participation and explaining the purpose of the study and assurance of anonymity was included. Two weeks after the electronic questionnaire was sent, if the response rate was not satisfactory, a follow-up letter was sent in an effort to increase the response rate. The telephone was also used to conduct follow-up interviews if necessary to obtain the required number of responses.

Description of pilot study. A pilot study was conducted during the summer of 2008, in the College of Engineering and Mineral Resources (CEMR) at West Virginia University. Seventeen faculty were contacted from different engineering departments to take part to the research. Most of them were part of a team especially created to prepare the ABET audit for the forthcoming year. The questionnaire was sent electronically and/or given to them through their secretary and an appointment, in most cases, was made with the respective faculty. Some engineering faculty were too busy to meet with the researcher and sent the questionnaire back with their responses or handed it back to the researcher. The researcher had numerous and lengthy conversations with many faculty about the research itself and about the adequacy of the terms used and meaning of the inquiry. The researcher received special help from faculty familiar with survey design. The different themes discussed during the interviews could fall into three categories: 1) relevance of the research; 2) questionnaire’s design; and 3) rewording of the items for better understanding.

Relevance of the research. Faculty showed interest for the research project, and discussed with enthusiasm how they perceived the impact of Outcome h in their department and in their teaching. One faculty member wrote: “Actual Study Abroad experiences are the best way to prepare students for the global business environment, but resources limit how many 
students can take part in such experiences.” Financial limitation seems to be one of the recurrent aspects dealing with the implementation of global experiences.

Questionnaire’s design. A table describing the global competencies' definitions was removed in order to simplify the document. The rubrics introducing the global competencies' table were modified from Low, Medium, and High to Not at all, Sometimes, Often, Almost always/High.

Rewording of the items for better understanding. Discussions were mostly spent in defining the specific meaning of terms such as Outcome h, Study Abroad, international experiences, Selected Humanity and Social Sciences courses, etc.

For items g, h and i, for instance, details about the percentage and the annual aspects of the data were discussed. Some words were deleted and others added for better understanding; however, sometimes suggestions made by one faculty contradicted the suggestions made by another; as a consequence, the researcher chose the most appropriated.

\section{Limitations}

1. Only 26 undergraduate engineering Colleges were considered. These 26 undergraduate Colleges belong to the SREB (Southern Regional Educational Board) area (see Appendix C).

2. Only universities with accredited undergraduate engineering programs participated in the study and consequently, findings may not be generalized to non-accredited programs.

3. Assessment was based on "perceived" levels of attainment of global competencies by engineering chairmen. 


\section{Chapter Four}

Findings

\section{Introduction}

The purpose of this study focused on the implementation of ABET accreditation criteria EC2000 with particular emphasis on Outcome h, which specifically calls for "the broad education necessary to understand the impact of engineering solutions in a global and societal context.” The emphasis was directed at understanding the relationship between the ways colleges of engineering comply with the recommendations of ABET EC2000 and the impact in terms of attention afforded to global competencies (GCA), the performance in attaining global competencies (GCP) and, ultimately the relationship if any, between global competencies attention (GCA) and performance (GCP). For the purpose of this study we have limited the approaches colleges of engineering have to comply with Outcome h to three options, which specifically are represented by three groups:

1. Selected Humanities and Social Sciences courses,

2. Adding topics to current engineering courses and,

3. Conducting Study Abroad programs in engineering.

The considerations are based on chairs’ perception of undergraduates’ global competencies performance and the attention given to them in their respective engineering programs.

This research helps to identify which of the three approaches proposed is used primarily to address global competencies and the attention and performance indices obtained according to Chairs' perceptions at SREB universities. No study on Outcome h and the different approaches used to address global competencies for SREB universities has been conducted before; however, 
it is possible to extrapolate the results obtained to most accredited engineering programs, since they all have to comply with ABET EC2000’s accreditation criteria.

\section{Demographics}

Participants in the survey were department chairs of accredited engineering programs from the SREB group, whose universities were classified according to the Carnegie classification, as Four-Year Doctoral institutions. All undergraduates engineering programs in the United States are accredited contrary to other areas where accreditation is not mandatory. Accreditation is a requirement for the delivery of degrees to students and to the existence of the engineering department per se. Before conducting the survey, it was anticipated that each university had 5 programs in the average, after conducting the survey it turned out that the universities had 6.5 programs in the average yielding 170 programs in 26 universities.

Originally 28 universities were part of the study, but while researching in the internet for email addresses, two universities were removed for not having engineering departments. Only 26 universities received the survey through Surveymonkey. The survey was administered the first time, on the $9^{\text {th }}$ of December of 2008, and the follow-up on the $15^{\text {th }}$ of January of 2009 . Forty seven responses were received out of 170 surveys sent, which represents a $27.6 \%$ return rate. Below is a graph representing the responses rate and the number of institutions having responded to the electronic survey. 


\begin{tabular}{|c|c|}
\hline \multicolumn{2}{|c|}{ Responses rate and the number of institutions } \\
\hline \# of Universities & \# of responses \\
\hline 1 & 4 \\
\hline 1 & 3 \\
\hline 4 & 2 \\
\hline 9 & 1 \\
\hline 8 & 0 \\
\hline 6 & \\
\hline
\end{tabular}

This chapter describes the detailed data and results from the survey and is divided into two main sections. The first section addresses the data obtained from the three research questions and the second section reports the data from the remaining questions contained in the survey. The analysis of the statistical tests are performed and interpreted according to the indications found in "Doing data analysis with SPSS; version 16” by Carver and Nash (2009).

The research questions were:

Research Question One

Is there a significant difference in the attention afforded to Global Competencies Attention (reflected by GCA scores) when comparing engineering departments who primarily use either selected Humanities and Social Sciences courses to satisfy Outcome h, as opposed to adding topics to current engineering courses or by conducting Study Abroad programs in engineering. 
Is there a significant difference in Global Competency Performance (GCP) scores when comparing engineering departments who primarily use either selected Humanities and Social Sciences courses to satisfy Outcome h, as opposed to adding topics to current engineering courses or by conducting Study Abroad programs in engineering?

\section{Research Question Three}

Can we predict, in a statistically significant fashion, using regression analysis, an engineering department’s GCP scores from their respective GCA scores?

\section{Null Hypotheses}

1. $\mathrm{Ho}_{1}$ : There is no significant difference in the attention afforded to Global Competencies Attention (reflected by GCA scores) when comparing engineering departments who primarily use either selected Humanities and Social Sciences courses to satisfy Outcome h, as opposed to adding topics to current engineering courses or by conducting Study Abroad programs in engineering.

2. $\mathrm{Ho}_{2}$ : There is no significant difference in Global Competency Performance (GCP) scores when comparing engineering departments who primarily use either selected Humanities and Social Sciences courses to satisfy Outcome h, as opposed to adding topics to current engineering courses or by conducting Study Abroad programs in engineering. 
4. $\mathrm{Ho}_{3}$ : there is no statistically significant regression analysis for predicting engineering departments GCP scores from their respective GCA scores.

Research Question One - One-Factor Independent Measures ANOVA

Global competency attention \#1 (see Appendix F). P-value is greater than alpha=0.05 (alpha $=0.77)$. In this particular case, the null hypothesis cannot be rejected and it can be concluded that there is no substantial evidence of at least one significant difference in means between the three groups.

Global competency attention \#2. P-value is smaller than alpha=0.05 (alpha =0.012) The null hypothesis is rejected and it is concluded that the data provide substantial evidence that there is a difference in means among the three groups. Data for Global Competency \#2 are presented in the table below: 
Table 2 Global Competency Attention \#2 - Awareness of global changes and issues driving these changes -ANOVA and Multiple Comparisons - Bonferroni

\begin{tabular}{|c|c|c|c|c|c|}
\hline & Sum of Squares & df & Mean Square & F & Sig. \\
\hline Between Groups & 3.593 & 2 & 1.797 & 4.905 & .012 \\
Within Groups & 15.385 & 42 & .366 & & \\
Total & 18.978 & 44 & & & \\
\hline
\end{tabular}

\begin{tabular}{|c|c|c|c|c|c|c|}
\hline \multirow[b]{2}{*}{$\begin{array}{l}\text { (I) Developing global } \\
\text { competencies }\end{array}$} & \multirow[b]{2}{*}{$\begin{array}{l}\text { (J) Developing global } \\
\text { competencies }\end{array}$} & \multirow{2}{*}{$\begin{array}{c}\text { Mean } \\
\text { Difference } \\
\text { (I-J) }\end{array}$} & \multirow[b]{2}{*}{$\begin{array}{l}\text { Std. } \\
\text { Error }\end{array}$} & \multirow[b]{2}{*}{ Sig. } & \multicolumn{2}{|c|}{$\begin{array}{c}95 \% \\
\text { Confidence } \\
\text { Interval }\end{array}$} \\
\hline & & & & & $\begin{array}{l}\text { Lower } \\
\text { Bound }\end{array}$ & $\begin{array}{l}\text { Upper } \\
\text { Bound }\end{array}$ \\
\hline \multirow[t]{2}{*}{$\begin{array}{l}\text { Through selected } \\
\text { Humanities and Social } \\
\text { Sciences courses }\end{array}$} & $\begin{array}{l}\text { By adding topics to } \\
\text { current engineering } \\
\text { courses }\end{array}$ & $-.654^{*}$ & .218 & .013 & -1.20 & -.11 \\
\hline & $\begin{array}{l}\text { Through Study } \\
\text { Abroad programs in } \\
\text { engineering }\end{array}$ & -.250 & .281 & 1.000 & -.95 & .45 \\
\hline \multirow[t]{2}{*}{$\begin{array}{c}\text { By adding topics to } \\
\text { current engineering } \\
\text { courses }\end{array}$} & $\begin{array}{c}\text { Through selected } \\
\text { Humanities and } \\
\text { Social Sciences } \\
\text { courses }\end{array}$ & $.654^{*}$ & .218 & .013 & .11 & 1.20 \\
\hline & $\begin{array}{c}\text { Through Study } \\
\text { Abroad programs in } \\
\text { engineering }\end{array}$ & .404 & .245 & .319 & -.21 & 1.01 \\
\hline \multirow[t]{2}{*}{$\begin{array}{l}\text { Through Study } \\
\text { Abroad programs in } \\
\text { engineering }\end{array}$} & $\begin{array}{c}\text { Through selected } \\
\text { Humanities and } \\
\text { Social Sciences } \\
\text { courses }\end{array}$ & .250 & .281 & 1.000 & -.45 & .95 \\
\hline & $\begin{array}{l}\text { By adding topics to } \\
\text { current engineering } \\
\text { courses }\end{array}$ & -.404 & .245 & .319 & -1.01 & .21 \\
\hline
\end{tabular}

*. The mean difference is significant at the 0.05 level. 
a. Engineering chairs believe that engineering departments provide better attention to global competency GCA \#2 when adding topics to current engineering courses than selecting Humanities and Social Sciences courses.

b. Engineering chairs believe that engineering departments provide comparable attention to global competency GCA \#2 when adding topics to current engineering courses than conducting Study Abroad programs in engineering.

c. Engineering chairs believe that engineering departments provide comparable attention to global competency GCA \#2 when conducting Study Abroad programs in engineering than selecting Humanities and Social Sciences courses.

Global competency attention \#3 (see Appendix G). P-value is smaller than alpha=0.05 $($ alpha $=0.02)$. In this particular case, the null hypothesis is rejected and it can be concluded that there is a possible substantial evidence of at least one significant difference in means between the three groups; however, in the multiple comparisons table no specific mention is expressed about a significant result at the level of 0.05 .

Global competency attention \#4 (see Appendix H). P-value is greater than alpha=0.05 $($ alpha $=0.51)$. In this particular case, the null hypothesis cannot be rejected and it can be concluded that there is no substantial evidence of at least one significant difference in means between the three groups.

Global competency attention \#5. P-value is smaller than alpha=0.05 (alpha = 0.003). The null hypothesis is rejected and it can be concluded that the data provide substantial evidence that there is a difference in means among the three groups. Data for Global Competency \#5 are presented in the table below: 
Table 3 Global Competency Attention \#5 - Personal adaptability to diverse cultures - ANOVA Multiple Comparisons -Bonferroni

\begin{tabular}{|c|c|c|c|c|c|}
\hline & Sum of Squares & df & Mean Square & F & Sig. \\
\hline Between Groups & 7.371 & 2 & 3.686 & 6.709 & .003 \\
Within Groups & 23.073 & 42 & .549 & & \\
Total & 30.444 & 44 & & & \\
\hline
\end{tabular}

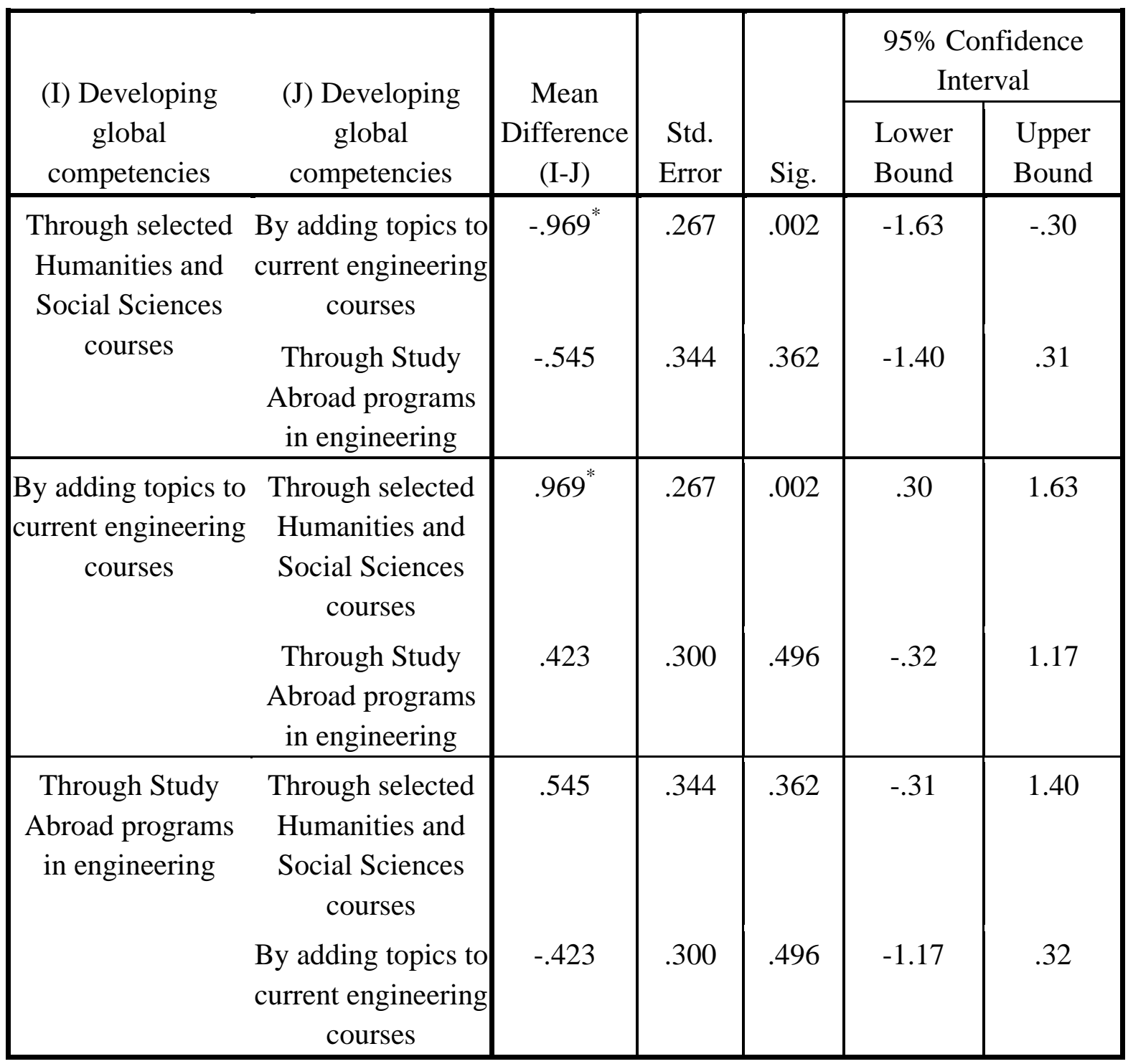

*. The mean difference is significant at the 0.05 level. 
a. Engineering chairs believe that engineering departments provide better attention to global competencies GCA \#5 when adding topics to current engineering courses than selecting Humanities and Social Sciences courses.

b. Engineering chairs believe that engineering departments provide comparable attention to global competency GCA \#5 when adding topics to current engineering courses than conducting Study Abroad programs in engineering.

c. Engineering chairs believe that engineering departments provide comparable attention to global competency GCA \#5 when conducting Study Abroad programs in engineering than selecting Humanities and Social Sciences courses.

Summary Research Question One - Global Competency Attention

Three significant results are found and are listed below:

\begin{tabular}{|c|c|c|}
\hline \multicolumn{3}{|c|}{ Research Question One } \\
\hline Global Competencies & P value & Significant? \\
\hline GCA1 & 0.77 & No \\
\hline GCA2 & 0.012 & Yes \\
\hline GCA3 & 0.02 & No but not for Post-hoc. \\
\hline GCA4 & 0.51 & Yes \\
\hline GCA5 & 0.003 & \\
\hline
\end{tabular}


1) Global Competency Attention (GCA)\#2 - Awareness of global changes and issues driving these changes.

$\mathrm{P}$-value is smaller than alpha $=0.05$ (alpha $=0.01)$. The null hypothesis is rejected and it is concluded that a difference exists between the means, in favor of the research hypothesis.

a. Engineering chairs believe that engineering departments provide better attention to global competencies GCA \#2 when adding topics to current engineering courses than selecting Humanities and Social Sciences courses.

b. Engineering chairs believe that engineering departments provide comparable attention to global competency GCA \#2 when adding topics to current engineering courses than conducting Study Abroad programs in engineering.

c. Engineering chairs believe that engineering departments provide comparable attention to global competency GCA \#2 when conducting Study Abroad programs in engineering than selecting Humanities and Social Sciences courses.

2) Global Competency Attention (GCA) \#5 - Personal adaptability to diverse cultures $\mathrm{P}$-value is smaller than alpha $=0.05$ (alpha $=0.003)$. The null hypothesis is rejected and it can be concluded that a difference exists between the means, in favor of the research hypothesis. 
a. Engineering chairs believe that engineering departments provide better attention to global competencies GCA \#5 when adding topics to current engineering courses than selecting Humanities and Social Sciences courses.

b. Engineering chairs believe that engineering departments provide comparable attention to global competency GCA \#5 when adding topics to current engineering courses than conducting Study Abroad programs in engineering.

c. Engineering chairs believe that engineering departments provide comparable attention to global competency GCA \#5 when conducting Study Abroad programs in engineering than selecting Humanities and Social Sciences courses.

3) Global Competency Attention \#3 (see Appendix G). P-value is smaller than alpha=0.05 $($ alpha $=0.02)$. In this particular case, the null hypothesis is rejected and it can be concluded that there is a possible substantial evidence of at least one significant difference in means between the three groups, but the main difference is not significant at the 0.05 level for the multiple comparisons table.

\section{Research Question Two - One-Factor Independent Measures ANOVA}

Global competency performance \#1 (see Appendix I). P-value is greater than alpha=0.05 $($ alpha $=0.83)$. In this particular case, the null hypothesis cannot be rejected and it can be concluded that there is no substantial evidence of at least one significant difference in means between the three groups. 
Global competency performance \#2 (see Appendix J). P-value is greater than alpha=0.05 $($ alpha $=0.69)$. In this particular case, the null hypothesis cannot be rejected and it can be concluded that there is no substantial evidence of at least one significant difference in means between the three groups.

Global competency performance \#3 (see Appendix K). P-value is greater than alpha=0.05 (alpha $=0.20)$. In this particular case, the null hypothesis cannot be rejected and it can be concluded that there is no substantial evidence of at least one significant difference in means between the three groups.

Global competency performance \#4 (see Appendix L). P-value is smaller than alpha=0.05 (alpha $=0.04$ ). The null hypothesis is rejected and it can be concluded that there is a possible substantial evidence of at least one significant difference in means between the three groups; however, there is no specific mention, in the multiple comparisons table, that the main difference is significant at the 0.05 level.

Global competency performance \#5 (see Appendix M). P-value is greater than alpha=0.05 (alpha $=0.07)$. In this particular case, the null hypothesis cannot be rejected and it is concluded that there is no substantial evidence of at least one significant difference in means between the three groups. 
Summary Research Question Two - Global Competency Performance.

Three significant results are found and are listed below:

\begin{tabular}{|c|c|c|}
\hline \multicolumn{2}{|c|}{ Re search Question Two } \\
\hline Global Competencies & P value & Significant? \\
\hline GCP1 & 0.83 & No \\
\hline GCP2 & 0.69 & No \\
\hline GCP3 & 0.20 & Yes, but not for Post-hoc \\
\hline GCP4 & 0.04 & No \\
\hline GCP5 & 0.07 & \\
\hline
\end{tabular}

The null hypothesis cannot be rejected for all global competencies except for GCP \#4, but the multiple comparison table for GCP\#4, does not mention any significant difference at the 0.05 level.

Global competency performance \#4 (see Appendix L). P-value is smaller than alpha=0.05 $($ alpha $=0.04)$. The null hypothesis is rejected and it can be concluded that there is a possible substantial evidence of at least one significant difference in means between the three groups.

Research Question Three - Multiple Regressions Analysis

Multiple regression global competency \#1 - (see Appendix N). $\mathrm{P}$ is greater than alpha = 0.05 (alpha $=0.14)$. There is no statistical evidence to reject the null hypothesis that states that all the slopes (or predictors) are equal to zero. GCA scores are $F=1.745, \mathrm{df}=5, \mathrm{p}=0.149$. 
Multiple regressions global competency \#2. P- value is smaller than alpha $=0.05$ (alpha $=0.014)$. There exists a statistical evidence to reject the null hypothesis that states that there is no significant predictive linear regression model.

Regression analysis reveals that individual GCP scores can be predicted from a linear combination of all GCA scores $(\mathrm{F}=3.36, \mathrm{df}=5, \mathrm{p}=0.014)$. The predictive model obtained from this analysis is the following:

Global Competency Performance \#2 = 1.443 + [0.638* Awareness of global changes and issues driving these changes $]-[0.362 *$ Personal adaptability to divers cultures].

Data for Global Competency \#2 are presented in the table below: 
Table 4 Multiple regressions global competency \#2 - Model Summary, ANOVA ${ }^{\mathrm{b}}$ and Coefficients $^{a}$

\begin{tabular}{|c|c|c|c|c|}
\hline Model & $\mathrm{R}$ & R Square & Adjusted R Square & Std. Error of the Estimate \\
\hline 1 & $.564^{\mathrm{a}}$ & .318 & .223 & .590 \\
\hline
\end{tabular}

a. Predictors: (Constant), 2) Global Competency \#5 - Personal adaptability to diverse cultures, 2) Global Competency \#3 - Knowledge of global organizations and business activities, 2) Global Competency \#1 - Ability to work in different international settings, 2) Global Competency \#2 - Awareness of global changes and issues driving these changes, 2) Global Competency \#4 - Capacity of effective communication across cultural and linguistic boundaries

ANOVA $^{\mathrm{b}}$
\begin{tabular}{|c|c|c|c|c|c|c|}
\multicolumn{2}{|c|}{ Model } & Sum of Squares & $\mathrm{df}$ & Mean Square & $\mathrm{F}$ & Sig. \\
\hline \multirow{2}{*}{1} & Regression & 5.854 & 5 & 1.171 & 3.358 & $.014^{\mathrm{a}}$ \\
& & & & & & \\
& Residual & 12.551 & 36 & .349 & & \\
Total & 18.405 & 41 & & & \\
\hline
\end{tabular}

a. Predictors: (Constant), 2) Global Competency \#5 - Personal adaptability to diverse cultures, 2) Global Competency \#3 - Knowledge of global organizations and business activities, 2) Global Competency \#1 - Ability to work in different international settings, 2) Global Competency \#2 - Awareness of global changes and issues driving these changes, 2) Global Competency \#4 - Capacity of effective communication across cultural and linguistic boundaries

b. Dependent Variable: 6) Global Competency Performance \#2 - Awareness of global changes and issues driving these changes 


\begin{tabular}{|c|c|c|c|c|c|c|}
\hline \multirow{2}{*}{\multicolumn{2}{|c|}{ Model }} & \multicolumn{2}{|c|}{$\begin{array}{c}\text { Unstandardized } \\
\text { Coefficients }\end{array}$} & \multirow{2}{*}{$\begin{array}{c}\text { Standardized } \\
\text { Coefficients }\end{array}$} & \multirow[b]{2}{*}{$\mathrm{T}$} & \multirow[b]{2}{*}{ Sig. } \\
\hline & & B & Std. Error & & & \\
\hline \multirow[t]{6}{*}{1} & (Constant) & 1.443 & .396 & & 3.643 & .001 \\
\hline & $\begin{array}{l}\text { 2) Global Competency } \\
\# 1 \text { - Ability to work in } \\
\text { different international } \\
\text { settings }\end{array}$ & .175 & .193 & .163 & .907 & .370 \\
\hline & $\begin{array}{l}\text { 2) Global Competency } \\
\text { \#2 - Awareness of } \\
\text { global changes and } \\
\text { issues driving these } \\
\text { changes }\end{array}$ & .638 & .181 & .636 & 3.525 & .001 \\
\hline & $\begin{array}{l}\text { 2) Global Competency } \\
\# 3 \text { - Knowledge of } \\
\text { global organizations } \\
\text { and business activities }\end{array}$ & -.146 & .155 & -.163 & -.939 & .354 \\
\hline & $\begin{array}{l}\text { 2) Global Competency } \\
\text { \#4 - Capacity of } \\
\text { effective } \\
\text { communication across } \\
\text { cultural and linguistic } \\
\text { boundaries }\end{array}$ & .139 & .164 & .156 & .851 & .400 \\
\hline & $\begin{array}{l}\text { 2) Global Competency } \\
\# 5 \text { - Personal } \\
\text { adaptability to diverse } \\
\text { cultures }\end{array}$ & -.362 & .158 & -.445 & -2.296 & .028 \\
\hline
\end{tabular}

a. Dependent Variable: 6) Global Competency Performance \#2 - Awareness of global changes and issues driving these changes

Multiple regressions global competency \#3 (see AppendixO). $\mathrm{P}$ - value is smaller than alpha $=0.05($ alpha $=0.02)$. There exists a statistical evidence to reject the null hypothesis that states that there is no significant predictive linear regression model. 
Regression analysis reveals that individual GCP scores can be predicted from a linear combination of all GCA scores $(\mathrm{F}=2.83, \mathrm{df}=5, \mathrm{p}=0.029)$. The predictive model obtained from this analysis is the following:

Global Competency Performance \#3 = $1.421+[0.539 *$ Knowledge of global organizations and business activities].

Multiple regression global competency \#4 (see Appendix P). P- value is smaller than alpha $=0.05($ alpha $=0.004)$, there exists a statistical evidence to reject the null hypothesis that states that there is no significant predictive linear regression model. However, no mention is made about the significance at the 0.05 level in the corresponding coefficients table. Regression analysis reveals that individual GCP scores can be predicted from a linear combination of all GCA scores $(\mathrm{F}=4.267, \mathrm{df}=5, \mathrm{p}=0.004)$. The predictive model obtained from this analysis is the following:

Global Competency Performance \#4 = 0.667 + [0.319* Capacity of effective communication across cultural and linguistic boundaries].

Multiple Regressions Global Competency \#5 (see Appendix Q). P- value is smaller than alpha $=0.05($ alpha $=0.000)$, there exists a statistical evidence to reject the null hypothesis that states that there is no significant predictive linear regression model.

$\mathrm{P}$ is smaller than alpha $=0.05$ (alpha $=0.05)$, the Null hypothesis is rejected for GCA \#5 and it is concluded that the independent variable has a statistically significant relationship to GCP \#5.

Regression analysis reveals that individual GCP scores can be predicted from a linear combination of all GCA scores $(\mathrm{F}=6.928 \mathrm{df}=5, \mathrm{p}=0.000)$. The predictive model obtained from this analysis is the following: 
Global Competency Performance \#5 = $0.885+$ [0.473* Personal adaptability to diverse cultures $]$

Summary Research Question Three - Multiple Regression Analysis

Four significant results are found and are listed below:

\begin{tabular}{|c|c|c|}
\hline \multicolumn{2}{|c|}{ Research Question Three } \\
\hline Global Competencies & P value & Significant? \\
\hline GC1 & 0.19 & No \\
\hline GC2 & 0.014 & Yes \\
\hline GC3 & 0.029 & Yes \\
\hline GC4 & 0.004 & Yes \\
\hline GC5 & 0.000 & Yes \\
\hline
\end{tabular}

1) For multiple regressions on GC\#2, the P-value is smaller than .05, which indicates significant relationship between the attention afforded and the performance obtained. Regression analysis reveals that individual GCP scores can be predicted from a linear combination of all GCA scores $(\mathrm{F}=3.36, \mathrm{df}=5, \mathrm{p}=0.014)$. The predictive model obtained from this analysis is the following:

Global Competency Performance \#2 = $1.443+[0.638 *$ Awareness of global change and issues driving these changes] - [0.362* Personal adaptability to divers cultures].

2) For multiple regressions on GC\#3, the P-value is smaller than .05, which indicates a significant relationship between the attention afforded and the performance obtained. 
Regression analysis reveals that individual GCP scores can be predicted from a linear combination of all GCA scores $(\mathrm{F}=2.83 \mathrm{df}=5, \mathrm{p}=0.029)$. The predictive model obtained from this analysis is the following:

Global Competency Performance \#3 = 1.421 + [0.539* Knowledge of global organizations and business activities].

3) For multiple regressions on GC\#4, the P-value is smaller than .05, which indicates a significant relationship between the attention afforded and the performance obtained. Regression analysis reveals that individual GCP scores can be predicted from a linear combination of all GCA scores $(\mathrm{F}=4.267 \mathrm{df}=5, \mathrm{p}=0.004)$. The predictive model obtained from this analysis is the following:

Global Competency Performance \#4 = 0.667 + [0.319* Capacity of effective communication across cultural and linguistic boundaries].

4) For multiple regressions on GC\#5, the P-value is smaller than .05, which indicates a significant relationship between the attention afforded and the performance obtained. Regression analysis reveals that individual GCP scores can be predicted from a linear combination of all GCA scores $(\mathrm{F}=6.928, \mathrm{df}=5, \mathrm{p}=0.000)$. The predictive model obtained from this analysis is the following:

Global Competency Performance \#5 = 0.885 + [0.473* Personal adaptability to diverse cultures].

\section{Description of Questionnaire}

The questionnaire consisted of nine sections, the last one being an open-ended question. The total number of questions, including the demographics profile of the population studied, and 
the matrix for global competencies represented 69 questions. The first three sections described the demographics specific to the universities participating in the survey and research. Section 4 summarized the five global competencies as defined by Brustein (2007). The five global competencies analyzed in the study are:

1. Ability to work in different international settings;

2. Awareness of global changes and issues driving these changes;

3. Knowledge of global organizations and business activities;

4. Capacity of effective communication across cultural and linguistic boundaries and;

5. Personal adaptability to diverse cultures.

Each of the five global competencies was assessed through 10 different item questions, resulting in 50 different responses. The following sections 5, 6 and 7 consisted of three questions aimed at understanding how accredited engineering departments dealt with the requirements of Outcome h. Section 8 of the survey consisted of 6 quantitative Likert scale questions with four categories from the lowest negative to the highest positive; Strongly disagree, Disagree, Agree, Strongly agree. Finally, section 9, consisted of an open-ended question, resulting in a list of eleven responses.

Analysis of the Survey Results - Survey Section 1, 2 and 3.

The survey conducted through Surveymonkey received 47 replies. Forty three came from Chairmen, Department Heads and Directors. Four came from engineering faculty to whom the survey had been forwarded by their respective chairs. 


\section{Number of full-time faculty members in your program?}

The majority of responses are situated between 8 to 23 full-time faculty members, which represent 37 answers out of 46 answers. The largest department has 60 full-time faculty working year long, whereas the two smallest departments have only 1 full-time faculty.

\section{What is the number of full-time undergraduate students in your program?} The majority of departments have between 100 to 300 undergraduate students which represent 27 answers out of 44 . Two departments have more than 1,000 undergraduate students; whereas seven departments have between 50 to 100 full-time undergraduates.

\section{Based on undergraduate students' demographics of your Department, please answer the following questions:}

On average, what percent of students, per year, seek Study Abroad with academic credits in engineering?

The most frequent answers for students studying abroad with academic credit in engineering is $2 \%$ and $5 \%$ which represents respectively 13 and 11 programs (total $=24$ out of 42). Five departments have 10\% of their undergraduates Study Abroad, and 6 departments answered 0 out of 42 answers.

On average, how many professors from your Department travel abroad, per year, with students for instructional purposes?

Eighteen participants responded that no professor traveled for instructional purposes with students and 12 responded that only one faculty on average traveled abroad for 
instructional purposes. Consequently, 30 responses fall between 0 and 1 faculty travelling abroad for instructional purposes out of 47 , which represents $63 \%$.

\section{On average, how many international exchange students do you host in your Department, per year?}

The majority of chairs (11) responded that their department did not have international exchange students. It is also observed that 31 engineering departments have between 1 to 10 exchange students per year, which represents 66\%. From the previous 31 engineering departments mentioned; 6 departments had 5 international students per year, and another group of 6 had 10 international students per year. The remaining departments had less than 4 students per year.

\section{Analysis of the Survey Results - Survey Section 4 (Matrix)}

Matrix - analysis of item questions 1 through 5. From a visual standpoint, if a line is drawn going through the highest percentile for each item question from 1 through 5 , we will get a vertical line almost identical for each global competencies studied with some differences for one or two item questions. Overall, the participants answered the rubric 2 (Sometimes) for item questions 1,2,3,5 and, rubric 1 (Not at all) for item question 4, for Global Competency \#1, \#2, and \#3. The same pattern described above is observed for GC \#2 and GC \#5 with a different response for item question 1 . For item question 1 , the respondents have chosen the rubric 3 (Often) as opposed to rubric 2 (Sometimes), (Figure 6 \& 9).

Descriptive results item questions 1through 5. In general, the participant's perception is that these global competencies were not addressed before ABET EC2000 criteria (item 4). It also 
appears that the respondents felt that these GC are sometimes addressed by the ABET EC2000 criteria (item 3). Effectively, results from item question 4 are negative (1= Not at all), whereas results from item question 3 are somehow positive (2= Sometimes), However and in accordance with the responses given in item question 3 and item question 4, the results show that ABET EC2000 has had an impact on how well these global competencies are addressed.

The answers given for item question 1 - How important are these global competencies in your department? and, item question 2 - How well are these global competencies addressed in the curriculum of your program? seem logically related in terms of importance given to them and the level to which these global competencies are addressed. Both item questions received the same rating (2= Sometimes) for the five global competencies. Only two global competencies (\#2 and \#5) are rated higher ( $3=$ Often) than the others global competencies in the responses given for item question 1 (Fig. 6 \& 9).

Effectively, GC\#2 - Awareness of global changes and issues driving these changes and, GC\#5 - Personal adaptability to diverse cultures on the other hand, are perceived as being more addressed by their respective engineering department than the other global competencies. Item question 5 indicates that Outcome h has sometimes brought changes in the curriculum to address these global competencies. It is somehow in line with the responses given for the other item questions of the survey that show, in their majority, the same level of interest 2 (Sometimes) on global competencies.

Another observation indicates that participating engineering departments seem to have a fairly similar experience in regard to the implementation of these global competencies before and after EC2000 for item question 1 to 5, as observed in the following figures. 


\section{Global Competency \#1}

1= Not at all; 2=Sometimes; 3= Often; 4= Always/High

\begin{tabular}{|c|c|c|c|c|c|}
\hline \multicolumn{6}{|c|}{ Ability to work in differ ent international settings } \\
\hline & 1 & 2 & 3 & 4 & $\begin{array}{l}\text { Response } \\
\text { Count }\end{array}$ \\
\hline $\begin{array}{l}\text { 1. How important are these global } \\
\text { competencies in your department? }\end{array}$ & $17.0 \%(8)$ & $46.8 \%(22)$ & $25.5 \%(12)$ & $10.6 \%(5)$ & 47 \\
\hline $\begin{array}{l}\text { 2. How well are these global } \\
\text { competencies addressed in the } \\
\text { curriculum of your program? }\end{array}$ & $21.7 \%(10)$ & $63.0 \%(29)$ & $15.2 \%(7)$ & $0.0 \%(0)$ & 46 \\
\hline $\begin{array}{r}\text { 3. How well do you feel these global } \\
\text { competencies are addressed by the } \\
\text { ABET EC } 2000 \text { criteria? }\end{array}$ & $27.9 \%(1$ & $48.8 \%(21)$ & $18.6 \%(8)$ & $4.7 \%(2)$ & 43 \\
\hline $\begin{array}{r}\text { 4. How well were these global } \\
\text { competencies addressed BEFORE } \\
\text { ABET EC } 2000 \text { criteria? }\end{array}$ & $74.4 \%$ & $20.9 \%(9)$ & $4.7 \%(2)$ & $0.0 \%(0)$ & 43 \\
\hline $\begin{array}{r}\text { 5. How much has Outcome } h \\
\text { brought change in the curriculum to } \\
\text { address these global } \\
\text { competencies? }\end{array}$ & $28.9 \%(13)$ & $55.6 \%(25)$ & $13.3 \%(6)$ & $2.2 \%(1)$ & 45 \\
\hline
\end{tabular}

Figure 5. Ability to work in different international settings

\section{Global Competency \#2}

1= Not at all; 2= Sometimes; 3= Often; 4= Always/High

\begin{tabular}{|c|c|c|c|c|c|}
\hline \multicolumn{6}{|c|}{ Awareness of global changes and issues driving these changes } \\
\hline & 1 & 2 & 3 & 4 & $\begin{array}{c}\text { Response } \\
\text { Count }\end{array}$ \\
\hline $\begin{array}{l}\text { 1. How important are these global } \\
\text { competencies in your department? }\end{array}$ & $2.1 \%(1)$ & & $42.6 \%(20)$ & $19.1 \%(9)$ & 47 \\
\hline $\begin{array}{l}\text { 2. How well are these global } \\
\text { competencies addressed in the } \\
\text { curriculum of your program? }\end{array}$ & $6.5 \%(3)$ & $52.2 \%(24)$ & $37.0 \%(17)$ & $4.3 \%(2)$ & 46 \\
\hline $\begin{array}{r}\text { 3. How well do you feel these global } \\
\text { competencies are addressed by the } \\
\text { ABET EC } 2000 \text { criteria? }\end{array}$ & $7.0 \%(3)$ & $51.2 \%(22)$ & $32.6 \%(14)$ & $9.3 \%(4)$ & 43 \\
\hline $\begin{array}{r}\text { 4. How well were these global } \\
\text { competencies addressed BEFORE } \\
\text { ABET EC } 2000 \text { criteria? }\end{array}$ & $62.8 \%$ & $32.6 \%(14)$ & $4.7 \%(2)$ & $0.0 \%(0)$ & 43 \\
\hline $\begin{array}{r}5 . \text { How much has Outcome } h \\
\text { brought change in the curriculum to } \\
\text { address these global } \\
\text { competencies? }\end{array}$ & $15.6 \%(7)$ & $55.6 \%(25)$ & $20.0 \%(9)$ & $8.9 \%(4)$ & 45 \\
\hline
\end{tabular}

Figure 6. Awareness of global changes and issues driving these changes 
Global Competency \#3

1= Not at all; 2=Sometimes; 3= Often; 4= Always/High

\begin{tabular}{|c|c|c|c|c|c|}
\hline \multicolumn{6}{|c|}{ Knowledge of global or ganizations and business activities } \\
\hline & 1 & 2 & 3 & 4 & $\begin{array}{l}\text { Response } \\
\text { Count }\end{array}$ \\
\hline $\begin{array}{l}\text { 1. How important are these global } \\
\text { competencies in your department? }\end{array}$ & $6.5 \%(3)$ & $47.8 \%(22)$ & $39.1 \%(18)$ & $6.5 \%(3)$ & 46 \\
\hline $\begin{array}{l}\text { 2. How well are these global } \\
\text { competencies addressed in the } \\
\text { curriculum of your program? }\end{array}$ & $17.4 \%(8)$ & $54.3 \%(25)$ & $26.1 \%(12)$ & $2.2 \%(1)$ & 46 \\
\hline $\begin{array}{l}\text { 3. How well do you feel these global } \\
\text { competencies are addressed by the } \\
\text { ABET EC } 2000 \text { criteria? }\end{array}$ & $25.6 \%(11)$ & $51.2 \%(22)$ & $16.3 \%(7)$ & $7.0 \%(3)$ & 43 \\
\hline $\begin{array}{r}\text { 4. How well were these global } \\
\text { competencies addressed BEFORE } \\
\text { ABET EC } 2000 \text { criteria? }\end{array}$ & $65.1 \%(28)$ & $27.9 \%(12)$ & $7.0 \%(3)$ & $0.0 \%(0)$ & 43 \\
\hline $\begin{array}{r}\text { 5. How much has Outcome } h \\
\text { brought change in the curriculum to } \\
\text { address these global } \\
\text { competencies? }\end{array}$ & $28.9 \%(13)$ & $53.3 \%(24)$ & $11.1 \%(5)$ & $6.7 \%(3)$ & 45 \\
\hline
\end{tabular}

Figure 7. Knowledge of global organizations and business activities

\section{Global Competency \#4 \\ 1= Not at all; 2=Sometimes; 3= Often; 4= Always/High}

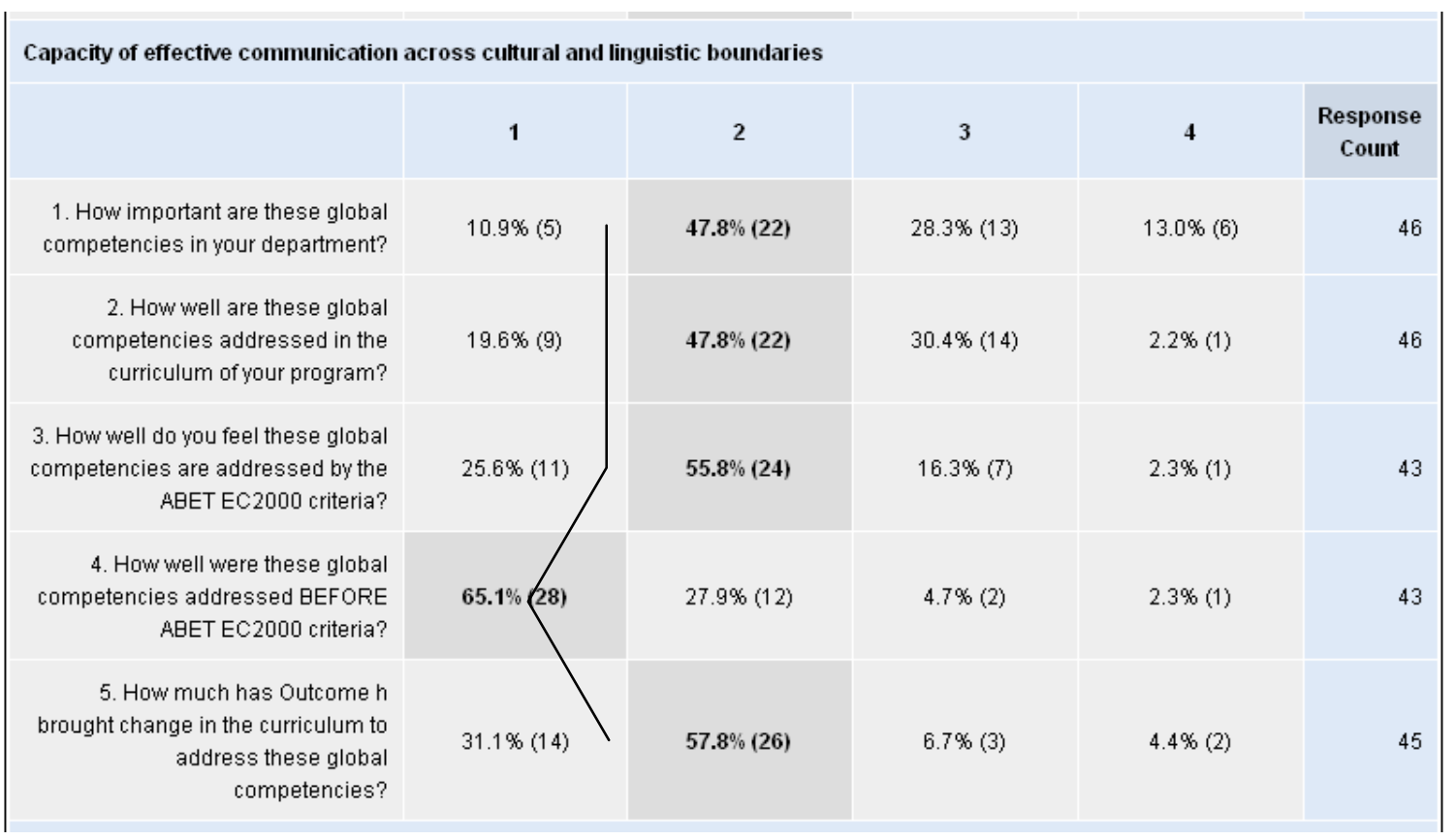

Figure 8. Capacity of effective communication across cultural and linguistic boundaries 


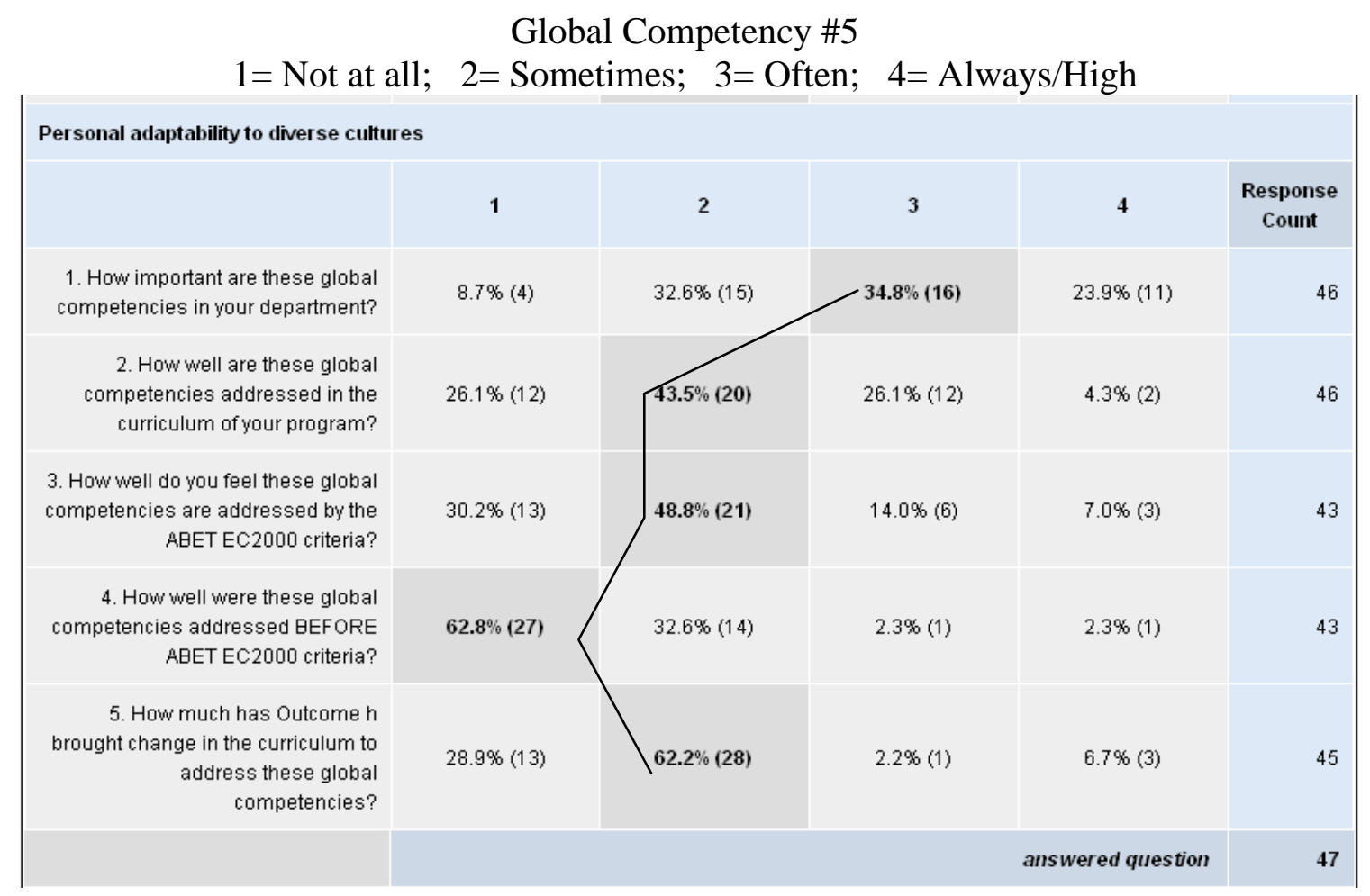

Figure 9. Personal adaptability to diverse culture

\section{Analysis of the Survey Results - Survey Section 5 (Matrix)}

Matrix - Analysis of item questions 6 through 10. From a visual standpoint, if a line is drawn going through the highest percentile for each item question from 6 through 10, we will get a vertical line almost identical for each global competencies, with some differences for one or two item questions. The participants answered the rubric 2 (Sometimes) for item questions 6, 7, 8, 10 and, rubric 3 (Often) for item question 9. However, everything being equal, the response differs only for item question 7 - How well did your graduates acquire these competencies BEFORE EC2000? The answer to this question shows an equal rating between 1 (Not at all) and 2 (Sometimes). 
Descriptive results item questions 6 through 10. In general, the participants' perception is that international experiences often promote the attainment of all five global competencies. Concerning item question 9 - How well international experiences promote the attainment of these competencies, the majority answered the rubric 3 (Often). However, the answer for rubric 2 (Sometimes) was unanimously chosen for item question 10 - How well these competencies can be attained without international experiences?

The response for item question 7 - How well did your graduates acquired these competencies BEFORE EC2000? is tied up between rubric 1 (Not at all) and rubric 2 (Sometimes) for GC\#1- Ability to work in different international settings, (Figure 10). The remaining item questions indicate a similar pattern consisting of systematically choosing rubric 2 (Sometimes) without any distinction between GC.

It is also observed that a contradiction appears between the responses given for item question 4 - How well were these global competencies addressed BEFORE ABET EC2000 criteria? And item question 7 - How well did your graduates acquired these competencies BEFORE EC2000?

Item question 4 shows a negative rating (1= Not at all), whereas item question 7 expresses a positive one ( 2 = Sometimes), and this for the five global competencies studied. As a general observation, most participants have chosen the response 2 (Sometimes) to answer the matrix item questions, which give a very consistent response rate.

Consequently, it indicates that participating engineering departments seems to have a fairly similar experience, in regard to the implementation of these global competencies, before and after EC2000 question 6 to 10, as observed in the following figures. 


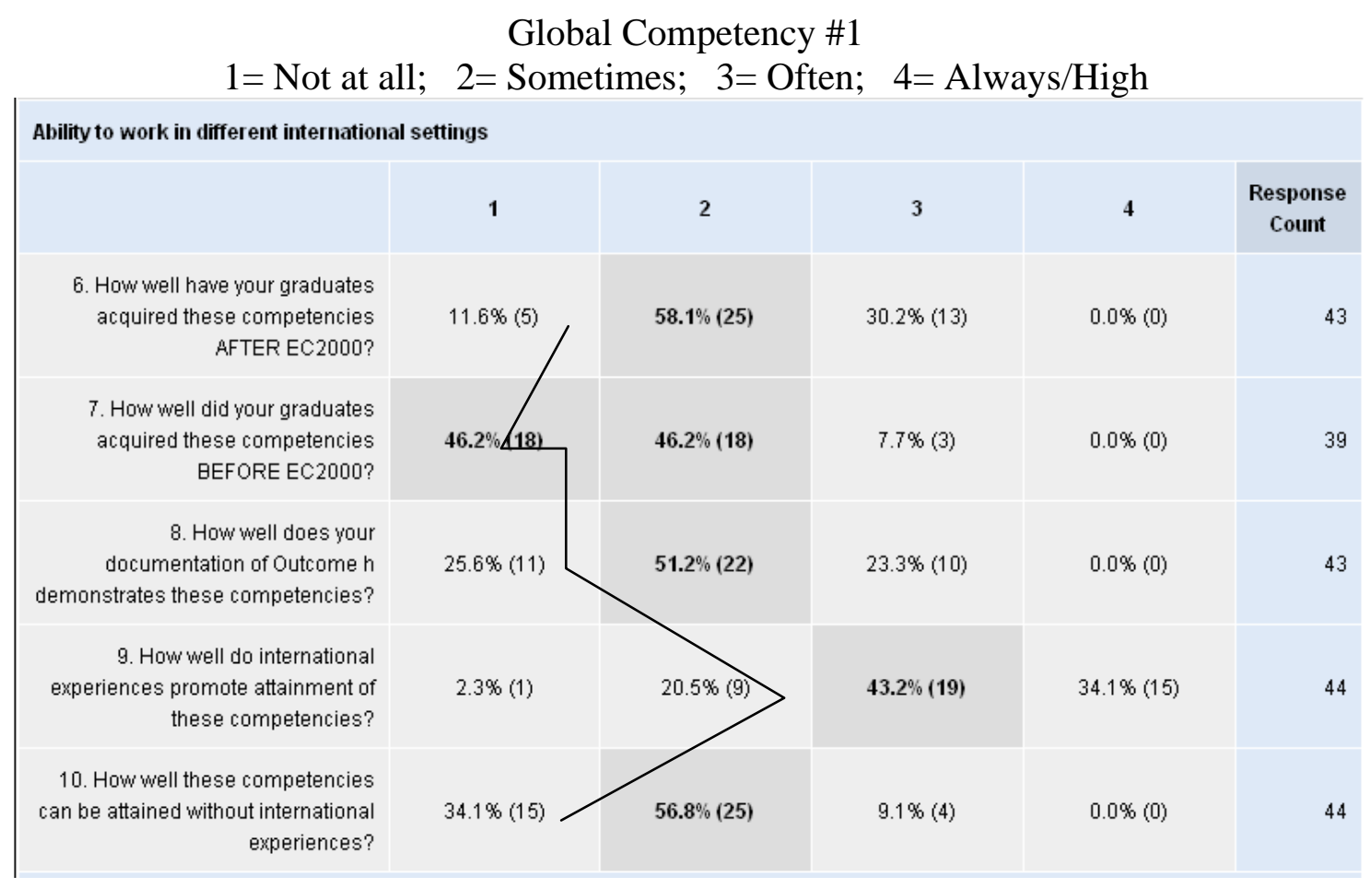

Figure 10. Ability to work in different international settings

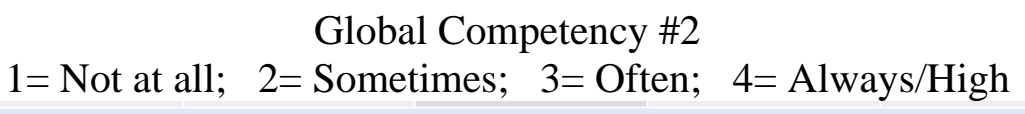

\begin{tabular}{|c|c|c|c|c|c|}
\hline \multicolumn{6}{|c|}{ Awareness of global changes and issues driving these changes } \\
\hline & 1 & 2 & 3 & 4 & $\begin{array}{c}\text { Response } \\
\text { Count }\end{array}$ \\
\hline $\begin{array}{r}\text { 6. How well have your graduates } \\
\text { acquired these competencies } \\
\text { AFTER EC2000? }\end{array}$ & $2.3 \%(1)$ & $46.5 \%(20)$ & $44.2 \%(19)$ & $7.0 \%(3)$ & 43 \\
\hline $\begin{array}{r}\text { 7. How well did your graduates } \\
\text { acquired these competencies } \\
\text { BEFORE EC2000? }\end{array}$ & $25.0 \%(10)$ & $65.0 \% 26)$ & $7.5 \%(3)$ & $2.5 \%$ (1) & 40 \\
\hline $\begin{array}{r}\text { 8. How well does your } \\
\text { documentation of Outcome } h \\
\text { demonstrates these competencies? }\end{array}$ & $7.0 \%(3)$ & $53.5 \% 2$ & $34.9 \%(15)$ & $4.7 \%(2)$ & 43 \\
\hline $\begin{array}{r}\text { 9. How well do international } \\
\text { experiences promote attainment of } \\
\text { these competencies? }\end{array}$ & $0.0 \%(0)$ & $22.7 \%(10)$ & $47.7 \%(21)$ & $29.5 \%(13)$ & 44 \\
\hline $\begin{array}{r}\text { 10. How well these competencies } \\
\text { can be attained without international } \\
\text { experiences? }\end{array}$ & $11.4 \%(5)$ & $50.0 \%(22)$ & $29.5 \%(13)$ & $9.1 \%(4)$ & 44 \\
\hline
\end{tabular}

Figure 11. Awareness of global changes and issues driving these changes 


\section{Global Competency \#3}

1= Not at all; 2=Sometimes; 3= Often; 4= Always/High

Knowledge of global organizations and business activities

\begin{tabular}{|c|c|c|c|c|c|}
\hline $\begin{array}{l}\text { 8. How well does your } \\
\text { documentation of Outcome } h \\
\text { demonstrates these competencies? }\end{array}$ & $9.3 \%(4)$ & $58.1 \%(25)$ & $30.2 \%(13)$ & $2.3 \%(1)$ & 43 \\
\hline $\begin{array}{r}10 . \text { How well these competencies } \\
\text { can be attained without international } \\
\text { experiences? }\end{array}$ & $9.3 \%(4)$ & $55.8 \%(2 / 4)$ & $23.3 \%(10)$ & $11.6 \%(5)$ & 43 \\
\hline
\end{tabular}

Figure 12. Knowledge of global or organizations and business activities

Global Competency \#4

1= Not at all; 2=Sometimes; 3= Often; 4= Always/High

\begin{tabular}{|c|c|c|c|c|c|}
\hline & 1 & 2 & 3 & 4 & $\begin{array}{c}\text { Response } \\
\text { Count }\end{array}$ \\
\hline $\begin{array}{r}\text { 6. How well have your graduates } \\
\text { acquired these competencies } \\
\text { AFTER EC2000? }\end{array}$ & $14.0 \%(6)$ & $46.5 \%\{20\}$ & $37.2 \%(16)$ & $2.3 \%(1)$ & 43 \\
\hline $\begin{array}{r}\text { 7. How well did your graduates } \\
\text { acquired these competencies } \\
\text { BEFORE EC2000? }\end{array}$ & $37.5 \%(15)$ & $50.0 \%$ & $10.0 \%(4)$ & $2.5 \%(1)$ & 40 \\
\hline $\begin{array}{r}\text { 8. How well does your } \\
\text { documentation of Outcome } \mathrm{h} \\
\text { demonstrates these competencies? }\end{array}$ & $16.3 \%(7)$ & $55.8 \%$ & $27.9 \%(12)$ & $0.0 \%(0)$ & 43 \\
\hline $\begin{array}{r}\text { 9. How well do international } \\
\text { experiences promote attainment of } \\
\text { these competencies? }\end{array}$ & $2.3 \%(1)$ & $25.0 \%(11)$ & $40.9 \%(18)$ & $31.8 \%(14)$ & 44 \\
\hline $\begin{array}{r}10 . \text { How well these competencies } \\
\text { can be attained without international } \\
\text { experiences? }\end{array}$ & $15.9 \%(7)$ & $56.8 \%\left(2^{5}\right)$ & $20.5 \%(9)$ & $6.8 \%(3)$ & 44 \\
\hline
\end{tabular}

Figure 13. Capacity of effective communication across cultural and linguistic boundaries 


\section{Global Competency \#5}

1= Not at all; 2=Sometimes; 3= Often; 4= Always/High

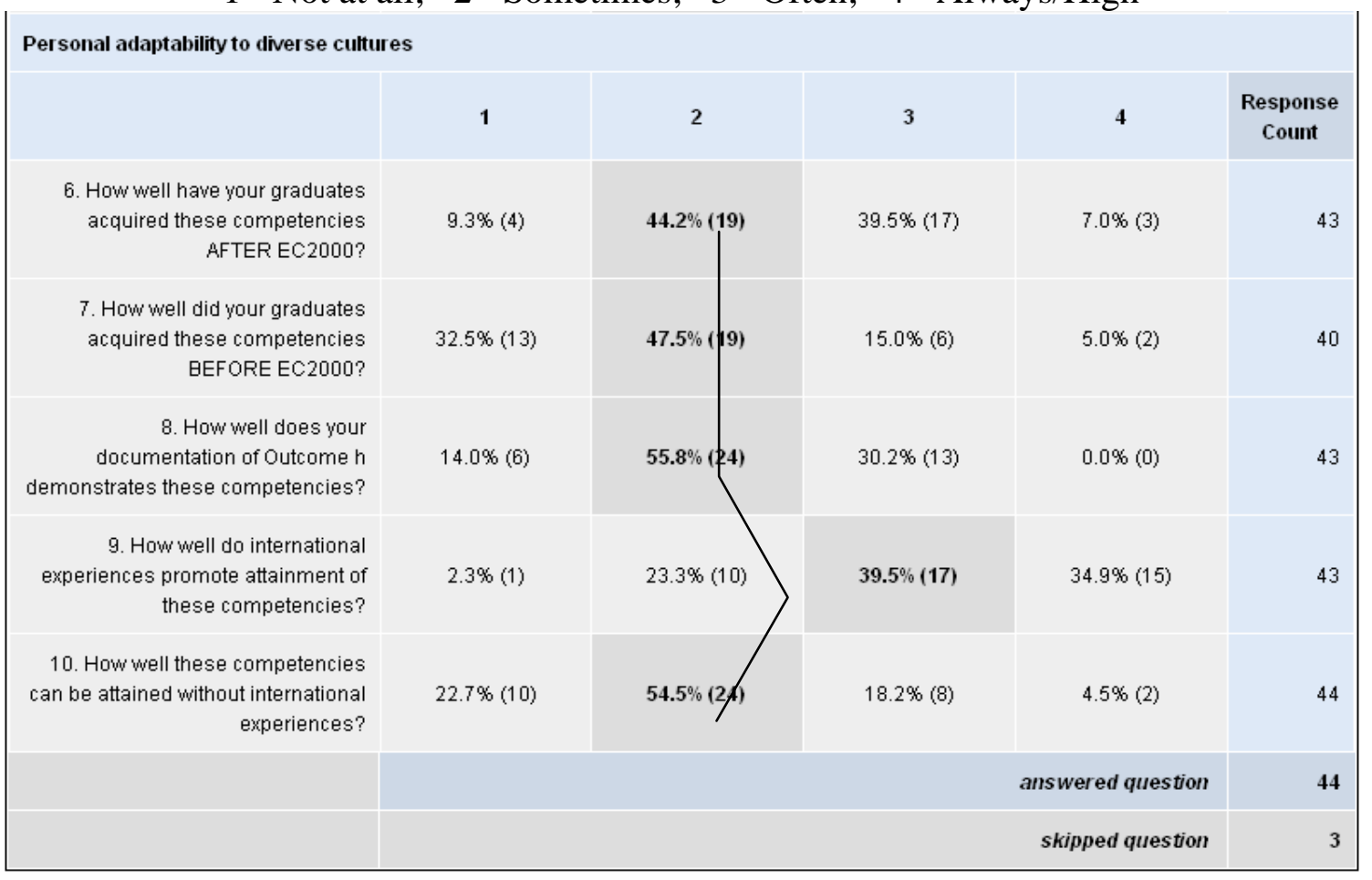

Figure 14. Personal adaptability to diverse cultures

\section{Analysis of the Survey Results - Survey Section 6 and 7}

The section 6 and 7 of the survey deals with questions related to international travel and how to develop global competencies in undergraduates engineering departments. 
Are there any specific courses in your Program that require international travel?

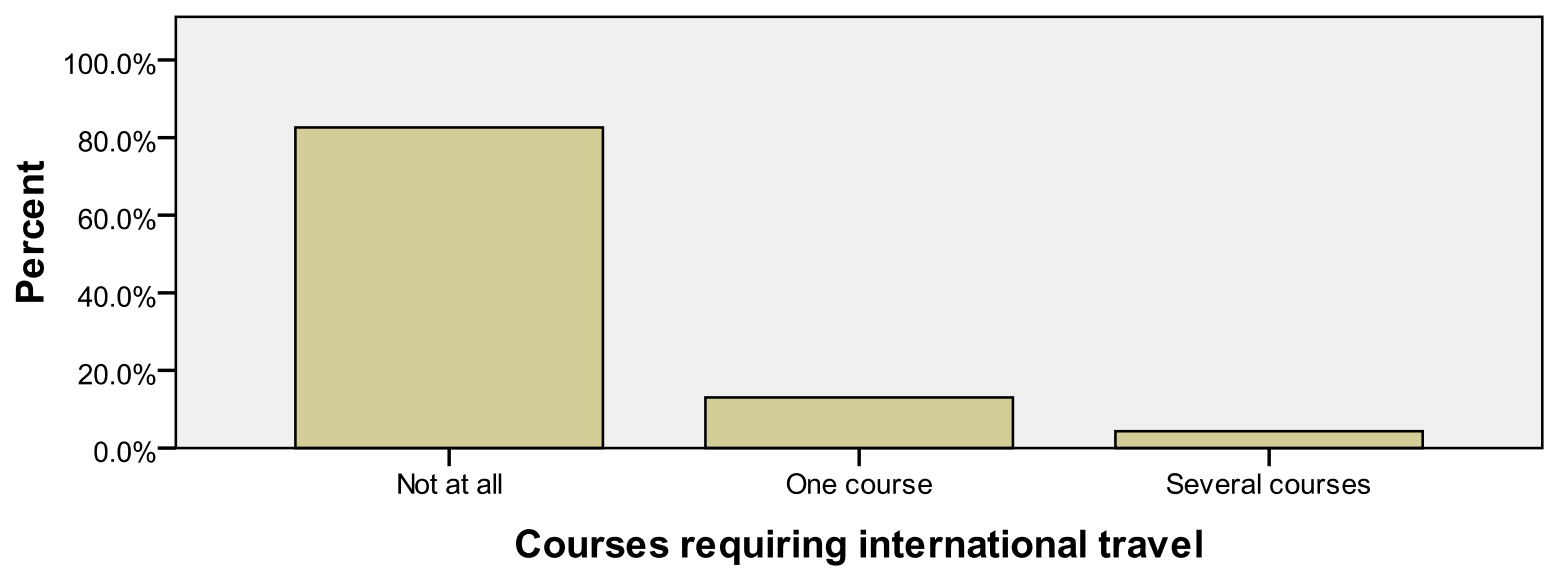

Figure 15. Survey Question 6

There is a majority of responses (83.0\%) indicating that there is no specific course requiring international travel in the respondents' engineering department. However, when courses requiring international travel are present; $12.8 \%$ of the departments offer one course and 4.3\% offer several courses requiring international travel.

What do you think should be the best way to prepare engineering students to develop global competencies?

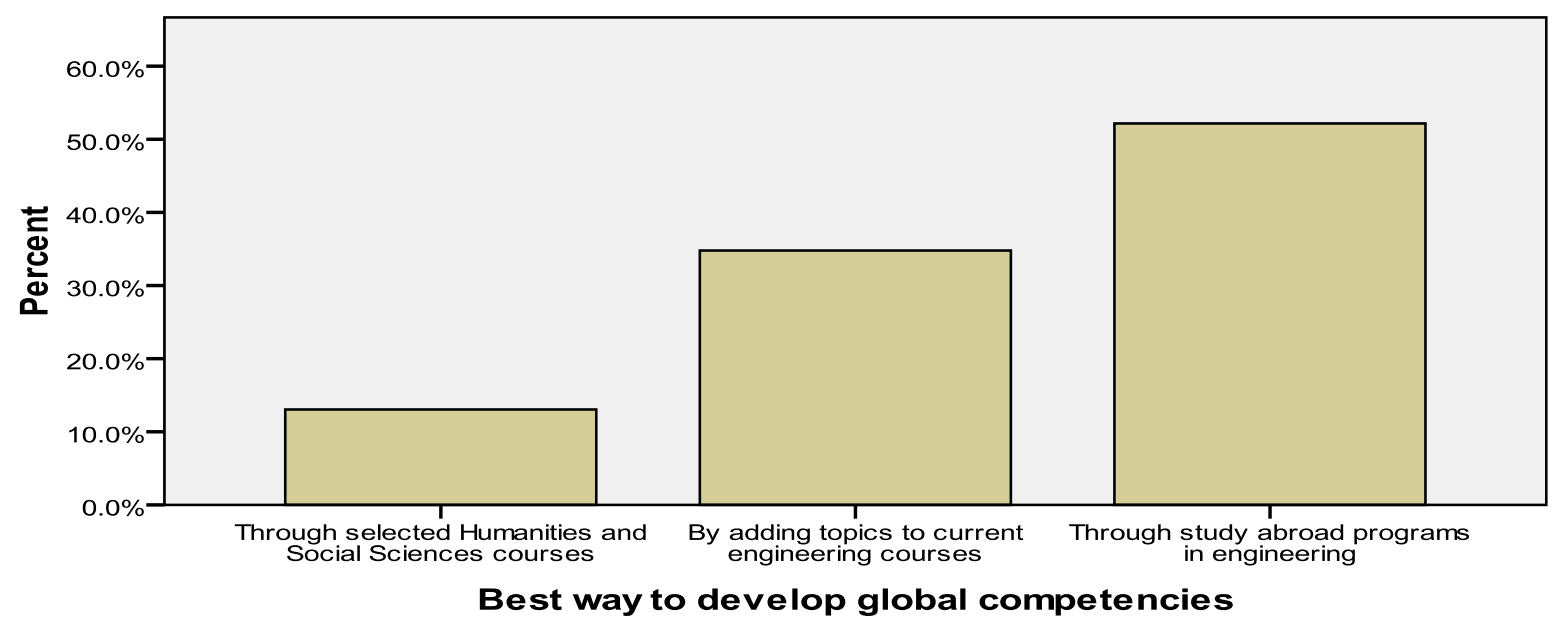

Figure 16. Survey Question 7

According to the respondents and in a descending order, the best way to prepare the students to develop global competencies is through Study Abroad programs in engineering 
(53.2\%); second, by adding topics to current engineering courses (34.0\%); and third, through selected Humanities and Social Sciences courses (12.8\%).

The Responses obtained echoes those made in the matrix item question 9 - How well do international experiences promote attainment of these competencies? Respondents answered systematically rubric 3 (Often).

How is your Department (PRIMARILY) preparing engineering students to develop global competencies? (Please, select ONLY one)

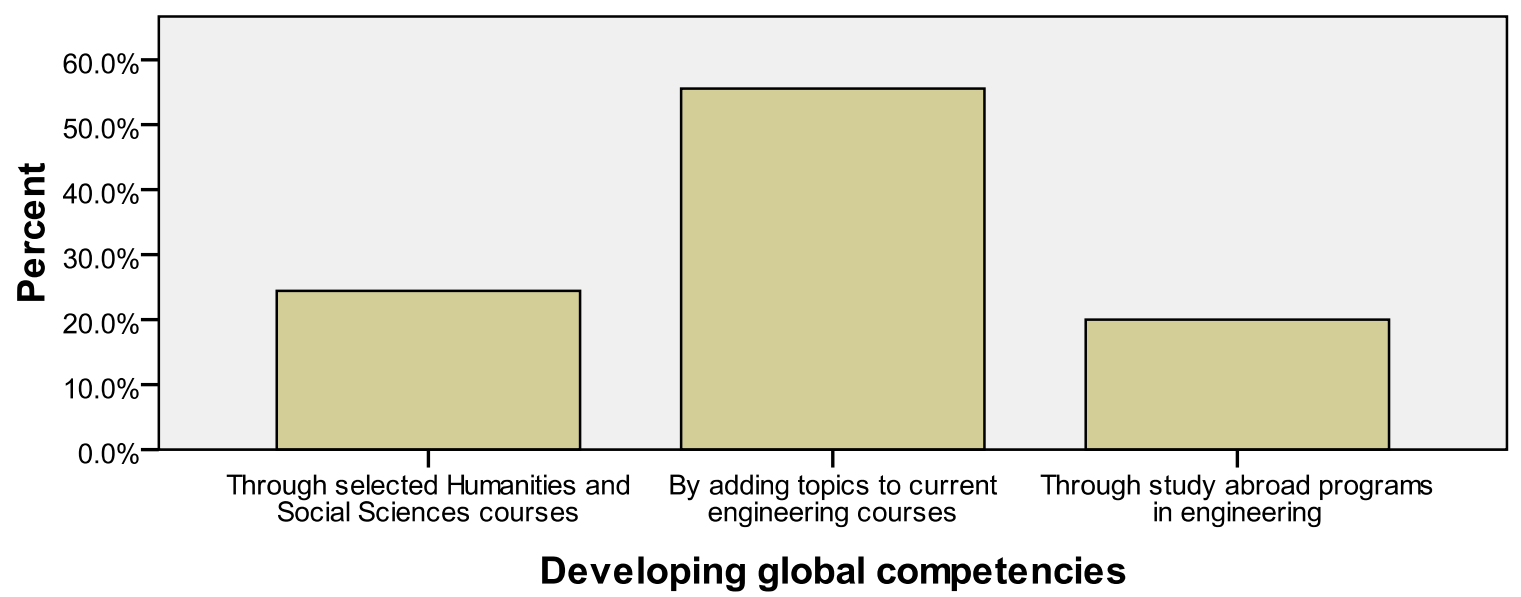

Figure 17. Survey Question 8

According to the respondents, engineering departments select primarily the approach of adding topics to current engineering courses to develop global competencies (56.5\%). Then, in second position they chose to select Humanities and Social Sciences courses (23.9\%) and, in third position they use Study Abroad programs in engineering (19.6 \%). In this instance, the order of preferences is reversed from the result obtained with item question 7 - How well do you think your engineering graduates acquired these global competencies before EC2000? The order of preferences in item question 7 was: first, using Study Abroad approach as a better way to 
develop global competencies; second, adding topics to current engineering courses; and third, selecting Humanities and Social Sciences courses. However, responses echo the results from matrix item question 10 - How well these competencies can be attained without international experiences? The answers for item question 10 were the same for the five global competencies and were principally responded with the rubric 2 (Sometimes). This particular result could suggest that other alternatives are explored for the promotion of global competencies than just the international experiences approach.

Analysis of the Survey Results - Survey Section 8

The section 8 of the survey deals essentially with questions regarding the implementation of Outcome h, before and after EC2000.

We have not done anything differently, BEFORE and AFTER EC2000, regarding Outcome h

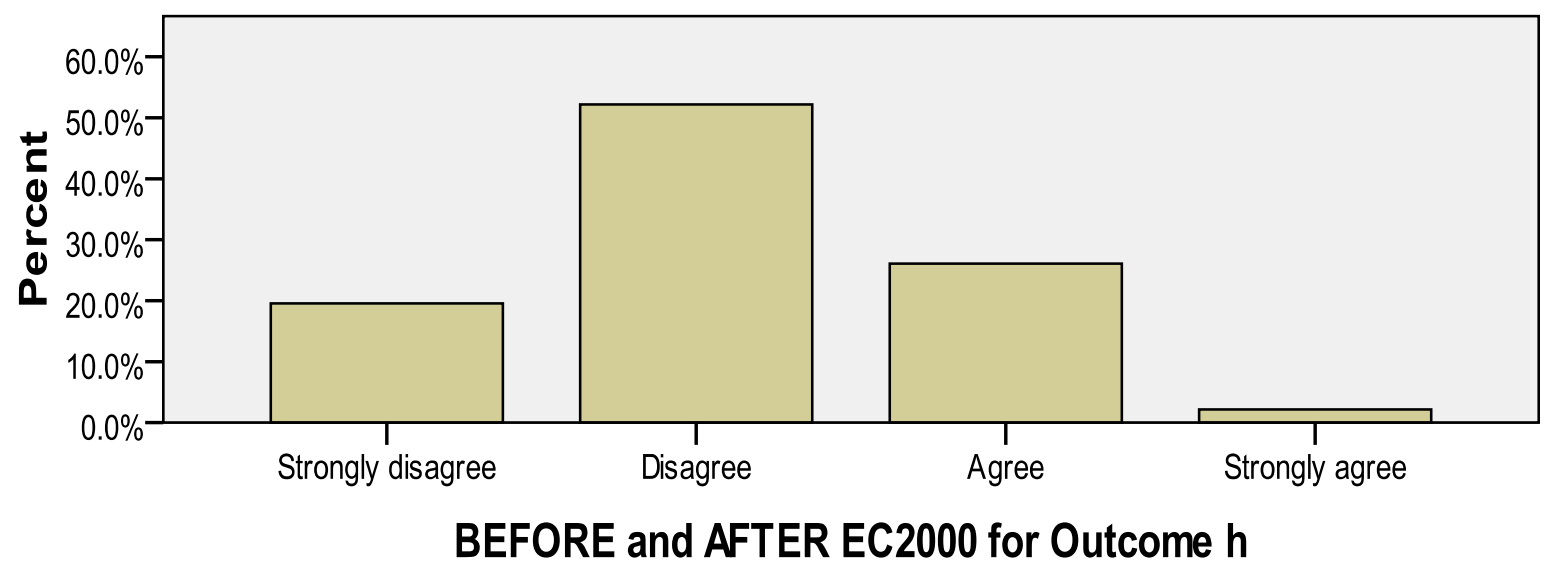

Figure 18. Survey Question 14

A majority of responses (Disagree $51.1 \%$ and Strongly disagree $19.1 \%$ total $70.2 \%$ ) indicates that engineering departments have done things differently BEFORE and AFTER EC2000, which implies that ABET had some impact on engineering curriculum. 
About Outcome $h$, we have improved the documentation on what we have been doing all along.

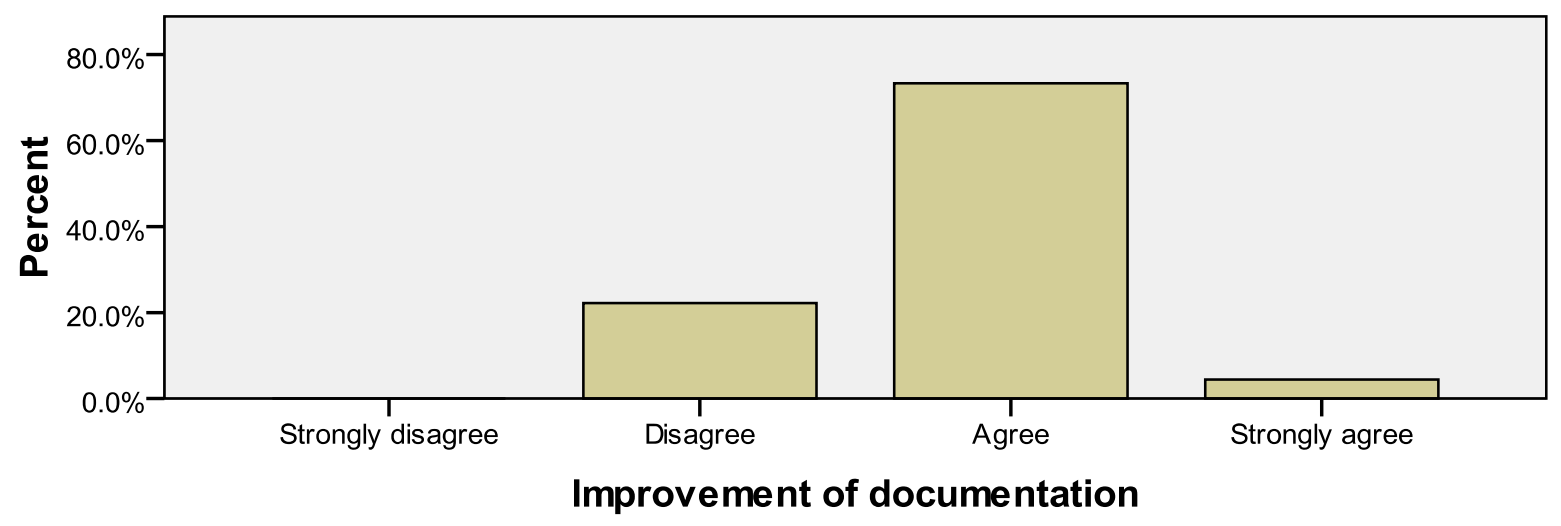

Figure 19. Survey Question 15

A majority of responses (Agree $71.7 \%$ and Strongly agree $4.3 \%$ total $76 \%$ ) indicates that Outcome h is better documented after ABET EC2000.

We made some changes IN SOME courses to comply with Outcome h.

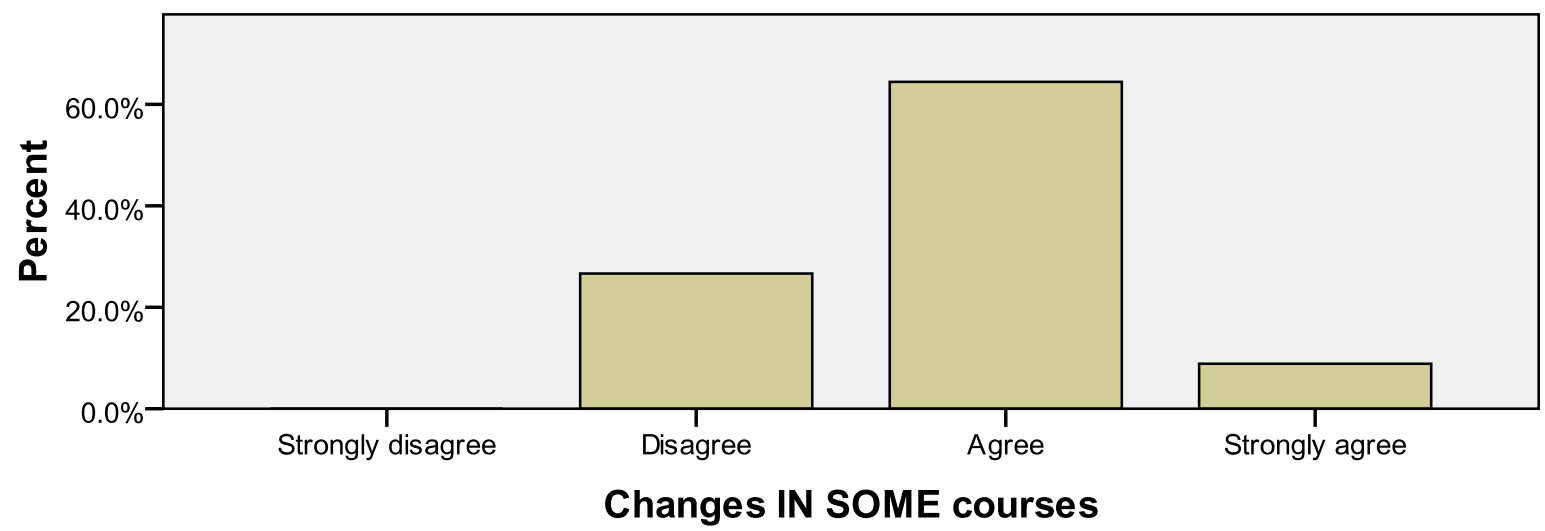

Figure 20. Survey Question 16

A majority of responses (Agree 63.0\%, Strongly agree 10.9\%, total $=73.9 \%$ ) indicates that some changes were made (in some courses) to comply with Outcome h.

We made some changes TO OUR curriculum to comply with Outcome h. 


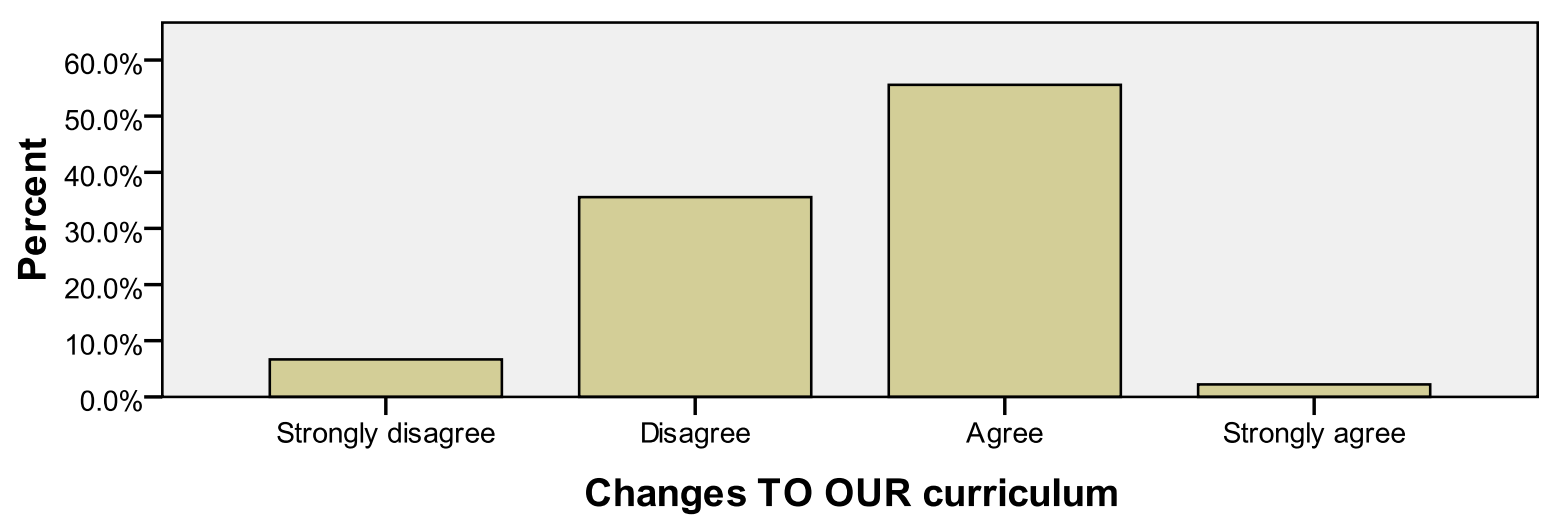

Figure 21. Survey Question 17

A majority of responses (Agree 54.3\%, Strongly agree 2.2\%, total $=56.5 \%$ ) indicates that some changes in the curriculum were made to comply with Outcome h.

We are looking into the curriculum to modify some required courses to add international experiences to comply with Outcome h.

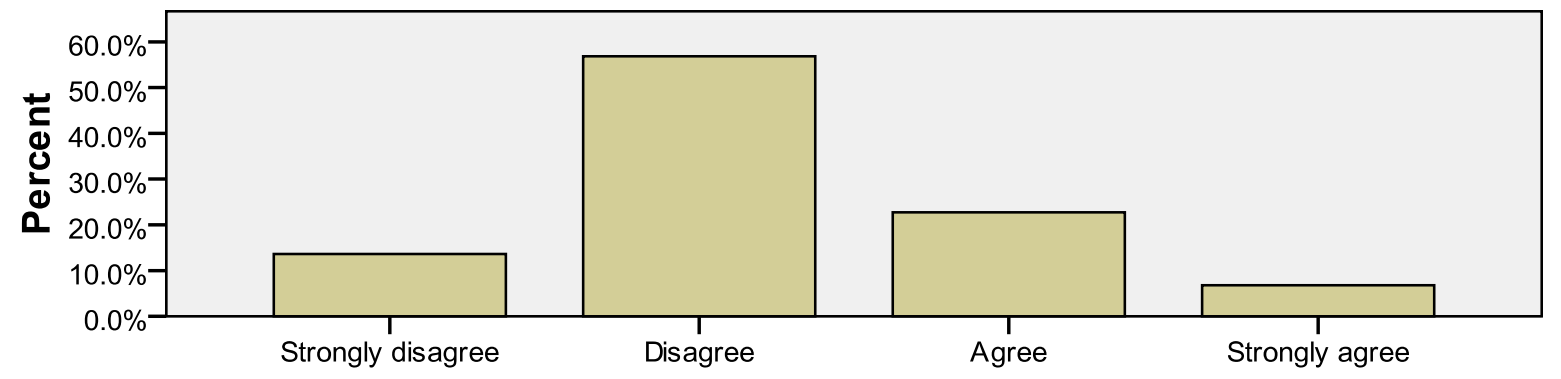

We are looking into the curriculum to modify some required courses...

Figure 22. Survey Question 18

A majority of responses (Disagree 55.6\%, Strongly disagree $13.3 \%$, total $=68.9 \%$ )

indicates that there is no modification of some required courses to add international experiences to comply with Outcome h. 
It is very important that our engineering graduates acquire global competencies to comply with Outcome h.

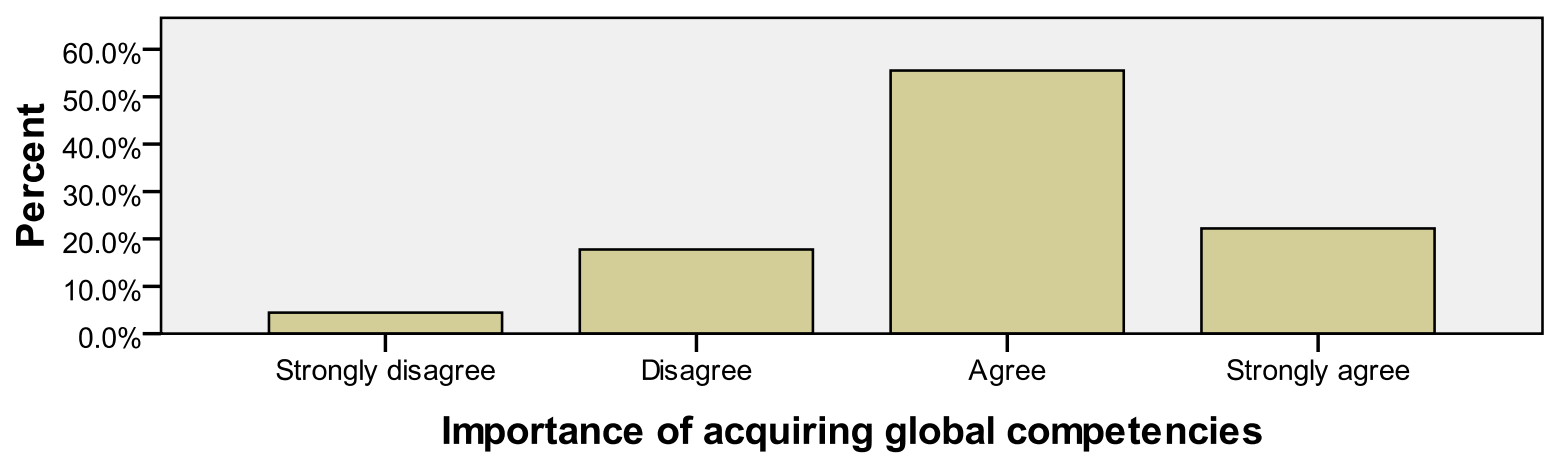

Figure 23. Survey Question 19

A majority of responses (Agree 56.5\%, Strongly agree21.7\%, total $=78.2 \%$ ) indicates that it is important for engineering graduates to acquire global competencies to comply with Outcome h.

Open-Ended Question - Survey Section 9.

Please, feel free to add comments...

The respondents' opinions are compiled into the list below:

- I look forward to receiving the results of your survey, and specifically, the survey results from similar programs. Historically, Ag. Eng. programs have been very strong on international outreach. Unfortunately, we are just beginning to recognize the importance of "global competencies" at the undergraduate level.

- We need to be cautious on trying to imply that the driving force on global competencies should be driven by ABET accreditation. They should be driven by the evolving needs around the world. Currently department and faculty in many places are overloaded with many tasks and activities and certainly we should not pursue making accreditation more 
complicated. The sad reality is that many colleges DO NOT have the necessary resources or infrastructure to do this well.

- I'll email comments:

Elizabeth,

I have enjoyed my international travel and association with diverse cultures of my graduates and some undergraduate students. However, I think that many people are using ABET Program Outcome "h" to promote a personal agenda if international experience, which is a distortion of the intent and relevance of " $\mathrm{h} "$. I sense from your survey that you make a strong connection with international experience and effectiveness of an engineer in the global environment. Most of our students who get international Study Abroad experience do it in 1) an academic environment, and 2) in a 2week Study Abroad course. Although a Study Abroad experience led by a faculty member is better than nothing, I believe it is nearly irrelevant to preparing students for engineering careers. Engineering is a process of making technology come to fruition within a human enterprise. Engineering is not doing calculations. Neither is engineering effectiveness related to being able to converse in a culturally correct manner, knowing a culture, or its history. To be effective, and engineering must, Engineering must cause people to change. Knowledge of language and national culture is not important. Understanding the human environment of business legal is. Humanities and social science courses can address aspects related to human "change", but memorizing case studies and terminology of the "intellectualism" of history, psychology, political science, etc. is not practicing effectiveness. Instruction is not doing. Further those instructors cannot relate human behavior to the complexity of technology. Study Abroad as a 
student, in a learning/instructional environment is not a process of bringing technology to fruition within a different culture. Accordingly, I think that ABET Outcome "h" can best be introduced in the curriculum by engineering professors who also have practice experience. My answer on your survey reflects that. You might not be able to see my viewpoint in the answers that you structured from your viewpoint.

Further, the issue is not international diversity, but effective engineering within diverse people. This includes age, education, race, disability, and religion diversity within the US. It also includes cultural diversity within the US (some are independent, some kowtow to the boss, some are into ballet, others into football, some are country, others city, some are INTJs and others ESFPs on the MBTI, ...). The issue is diversity not limited to international culture. As students work on teams and with faculty members on capstone projects, they are forced to bring technology to fruition within a diverse human environment. This is where they can learn. I believe the skills are easily translated to "global" and "h". Our Industrial advisors have explicitly said, effectively, "We hire students into entry-level engineering jobs based on engineering competency. International experience is irrelevant." Accordingly, the "h" ABET Program outcome is not nearly as important as most of the others. Do not presume that all are of similar importance. We have several electives that require international travel, but only a few students choose them. My response to Q6 reflects this. Your wording might be mistaken to mean "how many required courses include international travel" as opposed to "how many elective courses do your students chance to take that require international travel." Should you rephrase Q6?

Q5-10 needs rewording. Perhaps there is a missing word. 
ABET outcome "h" does not require global experience; it states that students have the ability to.

Researcher's response:

Dear Dr.,

First, I would like to thank you for your interesting and valuable comments about the research survey on Outcome h.

I understand your concerns and I agree with most of them. A two week "Study Abroad" is not going to make any difference in the effectiveness of an engineering student. However, when I am using the words “international experience”, I am referring to an engineering experience abroad with the supervision of an engineering instructor knowledgeable about the country where the experience is taking place. And this experience abroad should be given credits toward the students' degree. I think that it is important that engineers develop leadership skills in order to solve technological challenges that are most of the time related to the complexity of human behavior; I am thinking about global warming and the like. A relevant and significant international or global experience during their formative years should influence their thinking and behavior in a world that needs, more than ever, people knowledgeable in what they are doing but also in how to resolve problems and create opportunities in a global context. Again, thank you for your response.

Best Regards,

Response of Engineering Professor: 
Ahhh, I like your response.

You may find that many academics use international experience of their students in a one-upman-ship game, and will consider that their student's 2-week visits will count as a fully-adequate international experience.

- $\quad$ These questions are very difficult to answer definitively.

- $\quad$ It took me approximately $40 \mathrm{~min}$. to complete the survey.

- We would like for our students all to have the benefits of travel abroad, but there is currently no way to fund such an experience. We have a Birdsong Travel Abroad Program and several of our students have traveled and studied abroad via Rotary International fellowships. We are currently considering how we might emphasize the impact of what is happening around the world on the U.S. engineering profession.

- I have been at this institution only since 2001, so I had to guess based on my current understanding and reviewing past reports questions related to historical nature.

- This issue is still very ambiguous to our faculty and students. Especially when it comes to its benefits on our graduates. The most important question should be how do you accommodate such a requirement in an engineering curriculum with 126 credit hours?

- This will be interesting...however, many Civil Engineering programs are actually moving BEYOND “EC2000” and looking at the Civil Engineering Body of Knowledge (BOK), which provides much clearer guidance on the international aspects of the practicing engineer.

- We do not need to add a Study Abroad component to ABET for our programs. 


\section{Chapter Five}

\section{Discussion}

\section{Summary of the Study}

In this dissertation, the focus was on one aspect of the accreditation process of engineering programs in the United States, which is conducted under the standards of the Accreditation Board for Engineering and Technology (ABET). Engineering programs seeking accreditation are required to comply with the so called Engineering Criteria 2000 (EC2000), which has been divided into eleven "learning outcomes," labeled a through $\mathrm{k}$. This dissertation addresses one of them, “Outcome h”, which specifically calls for "the broad education necessary to understand the impact of engineering solutions in a global, economic, environmental, and societal context.” It is pertinent in the context of this dissertation to examine what engineering departments are doing to comply with Outcome h requirements for accreditation. Thus the purpose of this study is to examine the approaches engineering departments are using to respond to the challenges posed by Outcome h, through the study of how engineering students are acquiring global competencies, as perceived by chairs of engineering programs at universities of the SRBE (Southern Region Board of Education).

The current accreditation criterion Outcome h is one of the six so called "soft skills" considered within the accreditation criteria ABET EC2000, which essentially promotes awareness for engineering students to work in a global economy and the acquisition of the so called “global competencies.”

Engineering departments usually choose one of three approaches for the purpose of addressing the related issues of this outcome in the curriculum: 
a) Selecting humanities and social sciences courses,

b) Adding topics to current engineering courses,

c) Conducting Study Abroad courses in engineering.

More specifically, the emphasis of this research was directed at understanding the relationship between the approaches used by Southern Regional Educational Board (SREB) departments of engineering to comply with the recommendation of ABET EC2000 on Outcome h, and the impact in terms of global competencies indices of Attention (GCA) and Performance (GCP). The index of attention (GCA) reflects the level of effort directed at addressing global competencies in a given engineering program, while the performance index (GCP) reflects a relative level of attainment of the global competencies. This study uses the five global competencies (GC) identified by Brustein (2007):

1. Ability to work in different international settings (work in international settings),

2. Awareness of global changes and issues driving these changes (awareness global changes),

3. Knowledge of global organizations and business activities (global organizations),

4. Capacity of effective communication across cultural and linguistic boundaries (communications across cultures),

5. Personal adaptability to diverse cultures (personal adaptability). 


\section{Research Questions}

The research questions for this study were:

1. Is there a significant difference in the attention afforded to Global Competencies Attention (reflected by GCA scores) when comparing engineering departments who primarily use either selected Humanities and Social Sciences courses to satisfy Outcome h, as opposed to adding topics to current engineering courses or by conducting Study Abroad programs in engineering?

2. Is there a significant difference in Global Competency Performance (GCP) scores when comparing engineering departments who primarily use either selected Humanities and Social Sciences courses to satisfy Outcome h, as opposed to adding topics to current engineering courses or by conducting Study Abroad programs in engineering?

3. Can we predict, in a statistically significant fashion, using regression analysis, an engineering department’s GCP scores from their respective GCA scores?

For the purpose of this study an electronic survey (surveymonkey.com) was designed and sent to engineering chairs whose universities are part of the Southern Regional Educational Board (SREB) group. Forty seven (47) responses were received out of one hundred and seventy (170) surveys sent, which corresponds to a $27.6 \%$ return rate.

The results from the survey instrument were analyzed using both inferential and descriptive statistics in order to answer the three research questions. As a consequence, the 
following section is organized around: 1) the three research questions, and 2) four descriptive areas identified as: international experience, global competencies, Outcome h, and engineering programs on global competencies.

\section{Findings}

The findings of the study were:

- Global competencies \#2 and \#5 out of the five proposed by Brustein (2007) are given more attention than the rest. The two global competencies definitions are: GC\#2 Awareness of global changes and issues driving these changes, and GC\#5 - Personal adaptability to diverse cultures (Research Question One).

Based on the results obtained, it is worth noting that these two global competencies \#2 (awareness of global changes) and \#5 (personal adaptability) are repeatedly considered the most important ones of the five studied in this research, and consequently, are the ones receiving the most attention by engineering departments, which reflects the impact of globalization on engineering education as stated in the literature review by different engineering associations and organizations. In parallel, these results echo the data obtained from the survey descriptive section, which indicates that GC\#2 (Awareness of global changes) and, GC\#5 (personal adaptability) are considered more important than the other competencies studied.

With the results obtained, it is not possible to explain why these two global 
competencies (\#2 and \#5) compared to the others are perceived to have a more significant impact. From the survey descriptive section, it can be observed that after ABET EC 2000, global competencies as a whole, were all better addressed with a predominance for \#2 (awareness of global changes) and \#5 (personal adaptability). However, based on the literature review, this current research is the first study that differentiates these two global competencies from the others. On the other hand, there seems to be no consensus in international education and especially in engineering education programs to determine the degree of importance between global competencies. Even though the consensus in engineering education is that engineers need to be prepared for the $21^{\text {st }}$ century (NASULG, 2000), no consensus exists on what constitutes the specific global competencies to be taught and learned and more importantly, the strategies or methodologies to be used for their implementation.

- In this study, there is a difference in the attention afforded to GCA\#2 (awareness of global changes), GCA\#3 (global organizations), and GCA\#5 (personal adaptability) when comparing engineering departments' three different approaches to address Global Competencies Attention (GCA), (Research Question One).

- SREB engineering departments prefer to teach GC\#2 and \#5 as follows:

1) Adding topics to current engineering courses rather than Selecting Humanities and Social Sciences courses (Research Question One).

The data collected reflect the views of engineering chairs and provide a portrait of a group's opinion at a particular time. Research question number one attempts to answer what instructional approach is favored in engineering programs to comply with Outcome $\mathrm{h}$ and in particular with global competencies. In this research, there is a discrepancy 
between what engineering chairs believe is the best way to acquire global competencies and what they do to comply with their acquisition in their respective departments. Effectively, from the descriptive section, engineering chairs seem to believe that the best way to acquire global competencies is to Study Abroad; however, when they are asked what instructional approach they favor in their department, their prime answer is the integration of globalization topics to current engineering courses.

The difference between their thinking and their practice is due to the constraints related to the specific nature of studying abroad and the specificity of the engineering sequenced curriculum that does not cover all the necessary instructional materials in only a four year program (Rugarcia et. al., 2000). Besides the financial and administrative hurdles that studying abroad represents, one participant from the survey believes that Study Abroad does not adequately emphasize the fundamental characteristics of engineering work. In order to have a meaningful experience, he believes that students should be instructed by engineering professors who have practical experience and can teach change and technology. This particular comment is found in engineering articles recommending a better training of faculty for international practice (NSF, 2007; Jones, 1995). Another participant from the survey stated that faculty are too busy to dedicate time and effort to respond correctly to the challenge of Outcome h, citing the lack of resources and infrastructures. Similar remarks are found in the literature review that states that the new Outcomes represent additional workload for faculty who are not particularly inclined to change their way of teaching (Rugarcia et al., 2000).

From a practical point of view, adding topics to current engineering courses seems to be the less expensive and, easiest way to meet the requirements of Outcome h. 
But the aspect of developing global competencies is still under question, since engineering effectiveness, as one of the participants underlined it, is better learned by doing, and also that the majority of participants prefer studying abroad as a way to develop global competencies.

In conclusion, and assuming that engineering programs provide the same coherent program to comply with Outcome h, meaningful international learning experiences with hands-on experiences should be considered in order to respond effectively to Outcome h and global competencies (Ollis, 1999).

- The three approaches to address global competencies are similar in terms of impact on Global Competencies Performances (GCP) when comparing Southern Regional Educational Board (SREB) engineering departments, except for GCP\#4 (communications across cultures), (Research Question Two).

The second research question attempts to provide understanding of the relationship between the three different instructional approaches and the performance on global competencies. The three instructional approaches are:

a) Adding topics to current engineering courses;

b) Conducting Study Abroad programs in engineering, and

c) Selecting Humanities and Social Sciences courses.

The data reveal no significant difference in global competencies performance when comparing engineering departments using the three different approaches, exception done of GCP\#4 (communications across cultures).

It seems evident that outcomes produced by such different approaches are going to fit into a large range of outcomes, which in turn, may cause difficulty in terms of 
assessment. It also seems difficult to understand how classes in Humanities and Sciences, for instance, would be specifically related to engineering practice in a broader sociotechnical context, if not specifically offered for that purpose.

- For global competency \#2 (awareness of global changes), the results indicate a predictable impact of the combined level of attention given to competencies \#2 and \#5 (adaptability to diverse cultures) on the performance on competency \#2. Global Competency Attention (GCA) \#2 yields a positive effect on Global Competency Performance (GCP) \#2, and GCA\#5 yields a negative effect on GCP\#2. This result suggests a trade-off effect between GC\#2 and GC\#5 (Research Question Three). That is, if attention is given to awareness of global changes and issues driving them the increased performance on this competency occurs at the expense of the other competency which is adaptability to diverse culture, and the contrary is true as well.

- The results indicate that for GC\#2 (awareness of global changes), GC\#3 (knowledge of global organizations), GC\#4 (communications across cultures), and GC\#5 (adaptability to diverse culture) a predictable impact is observed for the level of attention given to them and the level of performance. This is not the case for GC\#1 (work in international settings). (Research Question Three). That is, the results suggest that the effort to work in international setting does not produce notable improvements in this competency, which corroborate the findings in the descriptive section, where it is observed that less than $17 \%$ engineering departments require courses including international travel. Additionally, a majority of chairs indicates that modification of required courses to add international experiences is not contemplated in order to comply with Outcome h. 
The following section of the findings is organized around four descriptive areas related to the research questions and the literature review: international experience, global competencies, Outcome h, and engineering programs on global competencies.

\section{Findings}

Findings on international experience:

- Study Abroad programs in engineering are thought to be the best way to prepare students to develop global competencies but are the last option when Engineering departments have to decide which one to choose for the development of global competencies in their respective department.

Although data reveal that engineering chairs believe that a Study Abroad programs in engineering is the best way to develop global competencies, Study Abroad is the last option chosen among the two other options proposed in this study. Study Abroad seems to be the best option, but the academic reality demonstrates that very few programs embrace and integrate Study Abroad within their degree programs, and are even less a requirement for their degree completion. Many programs do not view Study Abroad as central to the education of engineering students and often relegated international experience to add-on programs which corroborate Jones (1999) and_Ollis (1999) remarks in the literature review.

One participant's comment states the inadequacy of Study Abroad to engineering practice because of the personal agenda of some faculty to justify two weeks Study Abroad as a satisfying requirement for Outcome h. Nevertheless, an increasing number of universities are taking this issue with the seriousness that it deserves. The new 
orientation developed by several universities such as Purdue, Rhode Island and many more, is to consider international preparation not just as a question of cultural awareness, but rather as an opportunity to develop professional competences in a global context.

- Very few respondent engineering departments (less than 17\%) require courses including international travel. Additionally, chairs indicate that there is no modification of some required courses to add international experiences to comply with Outcome h (69\%).

SREB universities findings from this research report that less than $17 \%$ of engineering departments require international travel to satisfy Outcome h, and 70\% are not looking into the curriculum to modify some required courses to add international experiences to the program. Additionally, the results obtained reveal that most of the SREB student participation in international activities is around $2 \%$ to $5 \%$ of the engineering department population. The data collected remains relatively small compared to the recommendations made by various professional societies such as NSF, ASEE to support broadened experiences for engineering students. Jones (1999) and NSF (1995) suggest ways to remediate to the situation and suggest various ideas to be put into action, such as creating a dual program with another country or a work experience in a foreign country as a condition for the degree completion.

Although students can still be exposed to global competencies without any organized university programs, the Foundation Coalition (2007) insists that skills in engineering must be taught through the curriculum. Engineers’ internationalization readiness remains a challenge, although efforts are underway to identify better strategies to prepare the engineering workforce to confront globalization demands. 


\section{Findings on global competencies:}

- SREB engineering chairs' perception is that Global Competencies were not addressed prior to ABET EC2000. It also appears that respondents feel that these global competencies are addressed by ABET EC2000, especially GC \#2 and GC\# 5.

The results show that the impact of ABET EC2000 on how well global competencies are addressed after EC 2000 is similar to the findings of the Pennsylvania State University research (Latucca et al., 2006). The results from the Pennsylvania State University research indicates that chairs in engineering have observed substantial improvement and have increased their attention toward the implementation of EC 2000 Outcomes. After EC 2000, this current research on SREB engineering chairs reveals a better documentation of related activities as well as changes in some courses, together with some curriculum adaptations, have been implemented in order to comply with Outcome h.

Again and as previously mentioned, two global competencies are perceived to be more important than the others three by engineering chairs: global competency \#2 and \#5. When these two global competencies are combined, we get a global competency that emphasizes awareness and understanding of changes resulting in personal adaptability. The concepts of change and adaptability seem to be of importance for engineering education; these two notions are at the center of a changing technical and market workforce. The rapid pace and complexity of technological change as well as a global interconnectedness are expected to increase in an engineer's working lifespan. According to Peter Drucker (1994), a more global and more knowledge-based society 
will characterize the world of tomorrow, and because engineering is global in nature, its teaching calls for improvements in internationalizing engineering education strategies. Some believe that an holistic education is the solution that will help United States engineers maintain a leadership role worldwide (Grasso et al., 2007). Effectively, many in the engineering community believe that moving forward an improved engineering education program is a way to maintain employability of engineering graduates in a global marketplace (NAE, 2005; Borbogna, 1997; Jones et al., 2003).

The importance of understanding engineering implications in a broader context is a requirement that was addressed by ABET EC2000, almost 18 years ago. Even though there is a broad agreement in the engineering community about preparing students for a global workplace, engineering departments have difficulties deciding which approach would be the most adequate with the objective of Outcome $h$ and the pertinence of global competencies. At the same time, agreement on what defines the skills and abilities of global competencies is still an area under investigation and consensus has not been reached. One factor explaining this situation may be the vagueness of wording used in defining Outcome h; Outcome h statement sounds more like a suggestion than a clear guideline. Even though certain Outcomes are not given the same importance, as one participant's comment states it, there are many compelling reasons that advocate for a better understanding of Outcome h: 1) the engineer's responsibility for improving people's living conditions, and 2) the future unavoidable global challenges that will need to be resolved in collaborative international networks (Galloway, 2008).

- Before EC 2000 global competency \#1 (international settings), seems to have had the lowest level of acquisition. 
Global competency \#1 demonstrates a lower level of acquisition than the other GC before EC 2000. This situation is explained by the underrepresentation of Study Abroad program in the engineering education curriculum. Since EC2000 and Outcome h, an emphasis is being placed on international or global awareness, in response to the increasing multidisciplinary nature of engineering. However, the ability to adapt to global challenges is a never-ending discussion within the engineering community, and this situation encourages a more integrated and immersive approach to international experience into the engineering curriculum (Ollis, 1999; Jones, 1995).

Findings on Outcome h:

- A majority of engineering department responses indicates that they have made changes since EC2000. To comply with Outcome h, departments have: 1) improved their documentation (76\%); 2) made changes in some courses (74\%); and 3) made some changes in the curriculum (57\%).

- Similarly, results of this study indicate that Outcome $\mathrm{h}$ has sometimes brought changes into the curriculum to address global competencies, and an increased awareness that global competencies acquisition is important in complying with Outcome h requirements (78\%).

The results, from the descriptive section of the survey, corroborate the Pennsylvania State University findings about the impact of EC2000 on the documentation process and the changes made into the curriculum for Outcome h. By the same token, students' perception is that Outcome h has been significantly improved (Volkwein et al., 2006). 
However, from the literature review (Latucca et al., 2006), it was learned that Outcome $h$ is one of the skills that has not received systematic attention by engineering departments. Latucca et al., (2006) also point out that Outcome $h$ is one of the most difficult to implement.

In addition, results from the survey also indicate that SREB chairs believed that global competencies are part of Outcome h. This information is important since it can constitute a solid base of agreement from which innovative programs in engineering can be developed.

Findings on engineering programs and global competencies:

- The general observation drawn from the survey questions and responses results indicates that participating engineering departments seem to have a fairly similar experience in regard to implementation of global competencies before and after EC2000. The importance given to these five global competencies is positively correlated to the emphasis placed on them by engineering department.

Data reveals consistency of opinions from engineering chairs when they are dealing with Outcome h and global competencies. Because of identical academic preparation and practice, engineering professors have a tendency to consider EC2000 new outcomes or soft skills, not as important as the traditional engineering fundamentals that define their professional identity (Grose, 2004). According to French sociologist Pierre Bourdieu, "an habitus is at the principle of an objective harmonization of practices that confers regularity and objectivity to a group’s specific representation” (p. 265), a sort of status quo approach to curriculum modification. 
The inertia provoked by the status quo does not help the profession to respond rapidly to a changing environment (Fletcher, 2002). The explosion of knowledge and the global economy are changing the way engineers work and that changing context has produced changes in the engineering curriculum conveyed by EC2000. The introduction of new competencies to teach is in conflict with an already highly structured engineering curriculum. Especially since the trend in engineering education was to reduce the number of credits to allow an affordable degree to a more numerous student population, which in turn provides more revenue to the institution (Galloway, 2008). Moreover, engineering professors complained of not being told how to teach these new Outcomes without adding new courses (Rugarcia et al., 2000).

As for the requirements of Outcome h, each engineering department maintains a discretionary level as to what courses can be included into the curriculum, as long as accreditation guidelines are satisfied. This situation explains the reason most of the international opportunities within a curriculum depend on a faculty personal interest in globalization issues (Shuman et al., 2005; Mestenhausser \& Ellingboe, 2008). Other research from a Carnegie survey (1991) shows that American faculty, compared to other professors in other countries, are the least involved in international activities in general (Altbach, 1998). For these many different reasons, engineering students today do not have an international experience during their undergraduate years.

Nevertheless, there are many ways to respond to globalization, but no specific research has been performed to understand which practice provides the best cost and benefit ratio for undergraduate engineering students. However, leading universities in international affairs are offering a vast array of opportunities ranging from international 
internships to summer research programs during what many believe are the crucial students' formative years.

\section{Recommendations}

Recommendations for practice. Chairs of engineering departments, based on this study, could consider these recommendations aimed at improving Outcome h practice in their department or program. These suggestions are as follows:

1. To become aware of what other departments and programs are doing.

2. To share best practices among the departments and programs of engineering.

3. To reach consensus on the understanding of the implications of Outcome h among peer programs.

4. To develop an instrument of conceptual synthesis of goals to achieve in the attainment of Outcome h, based on consensus.

5. To use a holistic approach to the internationalization of Engineering programs to enable these programs to maintain international leadership in the education of their students.

6. To understand the cultural implications related to the implementation of Outcome h. Recommendations for future research. The research presented in this dissertation was aimed at understanding how engineering chairs perceive the implementation of the recommendations of EC 2000 in relation to Outcome h that promotes essentially global awareness. In light of the results, additional research is recommended in the following areas:

- To develop fundamental research on how to teach and assess global competencies and to what extent global competencies can be redefined. 
- To explore and understand the best practices on the educational impact of global experiences in engineering education.

- To analyze and assess engineering international programs on global competencies.

- To undertake research on learning behaviors and models focusing on developing and nurturing global competences in engineering.

- To explore fundamental research on the pedagogical value and impact of various international experiences considered as follow up practice for engineering courses.

- To integrate and design international educational experiences for professional practice within the accreditation recommendations.

- To focus research on cultural changes rather than curriculum changes regarding the implementation of Outcome h. 


\section{References}

American Council on Education. ACE (2002). Beyond September 11: A

Comprehensive National Policy on International Education. ACE American

Council on Education. Washington, D.C.: Center for Institutional and International Initiatives.

American Council on Education. ACE (2000). Internationalization of U.S. higher education. ACE American Council on Education. Washington, D.C.:ACE.

American Council on Education: Commission on International Education. (1998).

Higher Education's Role in Developing Human Resources. Education for Global Competence-America's Passport to the Future. Washington, DC: American Council on Education.

American Heritage Dictionary (1982). The American Heritage Dictionary ( $2^{\text {nd }}$ College Ed). Boston: Hougton Mifflin Company.

Accredited Board for Engineering and Technology. ABET (2003). Criteria for accrediting engineering programs. Baltimore, Md.: Engineering Accreditation Commission.

Accredited Board for Engineering and Technology. ABET (2004). Sustaining the change. Baltimore, Md.: National Science Foundation.

Altbach, P.G. (2004) Globalization and the university: Myths and realities in an unequal world. Tertiary Education and Management, 10, 3-25.

Altbach, P.G., \& Lewis, L.S. (1998) Internationalism and insularity.: American faculty and the world. Change. January/February, 54-55.

American Society for Engineering Education. ASEE (1998). How do you Measure 
Success? Designing Effective Processes for Assessing Engineering Education.

Washington, D.C.: American Society for Engineering Education.

Becker, G. S. (1964). Human Capital. Columbia: University Press.

Bloom, B.J., Englehart, M.D., Furst, M.D., Hill, E.J. and Krathwohl, D.R. (1956) Taxonomy of Educational Objectives: The Classification of Educational Goals. Handbook 1: Cognitive Domain. New York: David McKay.

Bonwell, C. C., \& Eison, J. A. (1991). Active learning: Creating excitement in the classroom. (ERIC Document Reproduction Service No. ED340272)

Bourdieu, P. (1996). Le mythe de la “mondialisation” et l'etat social europeen. Retrieved October 5, 2007, from http://www.homme-moderne.org

Bordogna, J. (1997). Making connections: The role of engineers and engineering education. The Bridge, 27(1).

Braudel, F. (1979). The wheels of commerce, Volume II of civilization and capitalism. New York: Harper and Row.

Brown, T. (1999). Challenging globalization as discourse and phenomenon. International Journal of Lifelong Education, 18(1), 3-17.

Buckeridge, J. St. J.S. (2000). A Y2k imperative: The globalization of engineering education. Global J. of Eng. Educ. 4(1), 19-24.

Brustein, W. I. (2007). Path to global competence: Preparing American college students to meet the world. Retrieved October 30, 2008, from http://www.iienetwork.org/page/84657/

Carnoy, M. (1999). Globalization and educational reform: What planners need to know. Paris: United Nations Educational, Scientific and Cultural Organization. 
Cheong, D. L.Y. (1999). Global financial and economic impact on science, engineering and technology development and engineering education in the $21^{\text {st }}$ century. European Journal of Engineering Education, 24(3), 221-233.

Carver, H. R. \& Gradwohl Nash, J. (2009). Doing data analysis with SPSS: version 16. Canada: Brooks/Cole, Cengage Learning.

De Witt, H. (1999) Changing Rationale for the Internationalization of Higher Education. International Higher Education, 15(1).

Drucker, F.P. (1994). The age of social transformation . The Atlantic Monthly, November, 53-80.

Felder, M. R. \& Brent, R. (2003). Designing and teaching courses to satisfy the ABET engineering criteria. Journal of Engineering Education, January, 7-18.

Finch, J. K. (1960). The story of engineering. New York: Harper and Row.

Fletcher, L. S. (2003, September). Is mechanical engineering obsolete?

[ASMENEWS]. Message posted to news://www.asmenews.org/columns/pspective.html Foundation Coalition. (FC). EC2000 a-k instructional modules.(n.d.). Retrieved October 05, 2007,from http://www.foundationcoalition.org

Friedman, L. T. (2006). The World is flat: a brief history of the twenty-first century. New York: Farrar, Strauss and Giroux.

Froyd, J., \& Frair, K., (2000). Theoretical foundations for the Foundation Coalition core competencies. Proceedings, American Society of Engineering Education Conference and Exposition. http://www.asee.org/acPapers/Froyd.pdf.

Galloway, P., \& the Nielsen-Wurster Group, Inc. (2008). The $21^{\text {st }}$ Century Engineer. American Society for Engineering Education, AC 2008-191 
Giddens, A. (1999). Lecture 1 - Globalization. London: BBC Reith Lectures.

Grasso, D., \& Martinelli, D. (2007, March 16). Holistic engineering. The Chronicle of Higher Education, p. B8.

Grayson, L. P. (1980). A brief history of engineering education in the united state. IEEE Transactions on Aerospace and Electronic Systems, 16(3), 373-392.

Grayson, L. P. (1993). The making of an engineer: An illustrated history of engineering education in the United States and Canada. United States of America: John Wiley \& Sons, Inc.

Grose, T. K.(2004). Opening a new book. ASEE PRISM online, 13(6), 1-6.

Harari, M. \& Reiff, R. F.(1993). Halfway there: A model for internationalizing. International Educator. Spring, 16-19 \& 46

Hill, D. (1984). A History of engineering in classical and medieval times. La Salle, IL: Open Court.

Historical Statistics of the United States, Millennial edition. (1975). Bureau of the Census. New York: Cambridge University Press.

Jones, R. C., \& Oberst, B. O. (2003). Canaries in the mineshaft: Engineers in the Global workplace. European Journal of Engineering Education. 28 (3), 395-402.

Jones, R.C. (1995) Educating engineers for international practice. Liberal Education, 81(4), 30-35.

Knight, J. (1994). Internationalization: Elements and checkpoints. Canadian Bureau for International Research. Ryerson polytechnic University: Ottawa, Canada.

Lattuca L. R., Strauss, L. C. \& Wolkwein, J. F. (2006). Getting in sync: Faculty and 
employer perceptions from the national study of EC2000. The International Journal of Engineering Education, 22(3),

Lattuca, L. R., Terenzini, P. T. \& Volkwein, J. F. (2006). Engineering change: A study of the impact of EC2000 (Executive Summary). Pennsylvania, United States: The Pennsylvania State University, Center for the Study of Higher Education.

Lattuca, L. R., Terenzini, P. T., Volkwein, F. \& Peterson, G. D. (2006). The changing face of engineering education. The Bridge, 36(2), 1-6.

Litalien, Charles (2006). Growing Globally: NAFSA Roundtable. Pratt \& Whitney Canada. Vice president, Engine Development \& Global Engineering.

Mallea, J. (1996). Internationalisation of higher education. In OECD Documents (Ed). The internationalization of higher education stakeholder views in North America. (pp.113129). Paris: OECD.

Marginson, S. \& Van Der Wende, M. (2006). Globalisation and higher education. Portugal: OECD-CERI.

Mestenhauser, J.A., Ellingboe, B.J. (1998). Reforming the higher education curriculum: internationalizing the campus. American Council on Education (ACE): Oryx Press.

NAFSA. (2003). Securing america's future: Global education for a global Age. Report of the Strategic Task Force on Education Abroad. NAFSA: Association of International Educators.

Natarajan, R. (2003). The symbiotic and synergistic relationship between industry 
and university. Retrieved October 05, 2007, from

http://www.oecd.org/dataoecd/47/11/1869533.pdf

National Academy of Engineering. NAE (2005). Educating the engineer of 2020:

Adapting engineering education to the new century. Washington, D.C.: The

National Academies Press.

National Association of State Universities and Land-Grant Colleges. (2000).

Expanding the international scope of universities. A strategic vision statement for

learning, scholarship and engagement in the new century. Washington, D.C.: National

Association of State Universities and Land-Grant Colleges.

National Science Foundation, NSF (1995). Restructuring engineering education: A

focus on change. Report of an NSF workshop on engineering education.

Washington, D.C.: National Science Foundation.

Ollis, D. (1999, June). International Programs for Engineering Students: Patterns

and Possibilities. Paper presented at the meeting of the American Society for Engineering Education, Charlotte, NC

Organization for Economic Cooperation and Development, OECD (2001) Education Policy Analysis. Paris: OECD.

Organisation for Economic Co-operation and development, OECD (1994) The views and activities of stakeholders on the internationalization of higher education. Paper presented at the international conference on learning beyond schooling: New forms of supply and new demand. Paris: OECD.

Parsons, W. B. (1939). Engineers and engineering in the renaissance. Cambridge:

MIT: Press. 
Perry, W.G. (1968). Forms of intellectual and ethical development in the college years New York: Holt, Rinehart and Winston.

Perkins, W. R. (1989). Introduction to “A brief history of electrical engineering education.” Proceedings of the IEEE, 86(8), 1788-1791.

Rompelman, O. (2000). Assessment of student learning: Evolution of objectives in engineering Education and the consequences for assessment. European Journal of Engineering Education, 25(4), 339-361.

Rugarcia, A., Felder, R. M., Woods, D. R. \& Stice, J. E. (2000). The future of engineering education: A vision for a new century. Chem. Engr. Education, 34(1), 16-25.

Schaeffer K. R. (2003). Theories of Globalization. Understanding globalization: A very short introduction. ( $2^{\text {nd }}$ ed.). Maryland: Rowman \& Littlefield Publishers, Inc. Schmidt, J., Pertmer, G., \& Ainane, S. (2002). Keeping the flame alive: what happens after the ABET visit. Paper presented at the meeting of the American Society for Engineering Education (ASEE), Montreal, CA

Shuman, L.J., Besterfield-Sacre, M. \& McGourtry, J. (2005). The ABET "professional skills” Can they be taught? Can they be assessed? Journal of Engineering Education, January, 41-55.

Splitt, G. F. (2003). Systemic engineering education reform: A grand challenge. The Bent of Tau Beta Pi, spring, 29-34.

Stromquist, N. P. (2002). Globalization, the I, and the other. Current Issues in Comparative Education, 4(2), 1-7.

Tillett, A. D. and Lesser, B. (1992). International students and higher education: 
Canadian choices (Research Paper No. 2). Ottawa: Canadian Bureau for International Education.

Volkwein, F. J., Terenzini, P. T., Strauss, L. C. \& Sukhbaatar, J. (2003). Engineering change: A study of the impact of EC2000. Int, J, Eng. Ed., 20(2), 1-11.

Volkwein, J.F., Lattuca, L. R., Harper, B. J. \& Domingo, R. J. (2006). Getting in sync: The impact of accreditation on student experiences and learning outcomes. Paper presented at the meeting of the Association for Institutional Research, Chicago, IL.

Windham, D.M. (1996). Internationalisation of higher education. In OECD Document (Ed).Overview and main conclusions of the seminar. (pp. 7-29). Paris: OECD.

Wagner, P. (2004). Globalization and higher education. In J. K. Odin \& P. T. Manicas (Eds.), Higher education in an era of globalization: What is at stake? (pp. 7-23). Honolulu: University Hawai, I Press. 


\section{APPENDIX A \\ Engineering Education Coalition and Participating Institutions}

ECSEL (Engineering Coalition of Schools for Excellence in Education and Leadership) 19902001

The City College of the City University of New York

Howard University

MIT

Morgan State University

Penn State

University of Maryland

University of Washington

Synthesis 1990-2001

California Polytechnic State University at San Luis Obispo

Cornell University

Hampton University

Iowa State University

Southern University

Stanford University

Tuskegee University

University of California at Berkeley

SUCCEED (Southeastern University and College Coalition for Engineering Education) 19922003

Clemson University

Florida A\&M University - Florida State University

Georgia Institute of Technology

North Carolina Agricultural and Technical State

University of Florida

Virginia Polytechnic Institute and State University

Gateway 1992-2003

Columbia University

Cooper Union

New Jersey Institute of Technology

Drexel University

Ohio State University

Polytechnic University

University of South Carolina

Foundation 1993-2004

Arizona State University

Rose-Hulman Institute of Technology

Texas A\&M University 
University of Alabama

University of Massachusetts Dartmouth

University of Wisconsin Madison

Texas Woman's University

Maricopa Community College District

Greenfield 1994-2005

Wayne State University

Lawrence Technological University

Lehigh University

Michigan State University

University of Detroit Mercy

http://www.foundationcoalition.org/home/foundationcoalition/engineering_coalitions.html 


\section{APPENDIX B}

\section{Bloom Taxonomy}

Besterfield-Sacre, M., L.J. Shuman, H. Wolfe, C.J. Atman, J. McGourty, R. Miller, B. Olds, and G. Rogers. "Defining the

Outcomes - A Bloom's Taxonomy Approach to EC2000” to appear in IEEE transactions on Engineering Education, April 2000.

Outcome H: The broad education necessary to understand the impact of engineering solutions in a global and societal context (Updated 04/11/00)

\begin{tabular}{|c|c|c|c|c|c|c|c|}
\hline Definitions & Knowledge & Comprehension & Application & Analysis & Synthesis & Evaluation & Valuation \\
\hline $\begin{array}{l}\text { Outcome Element: } \\
\text { Identifying Im- } \\
\text { pacts: This set of } \\
\text { attributes deals with } \\
\text { the general skill of } \\
\text { identifying impacts } \\
\text { of engineering solu- } \\
\text { tions, apart from the } \\
\text { societal or global } \\
\text { knowledge that is } \\
\text { used in the process }\end{array}$ & $\begin{array}{l}\text { States the steps in a } \\
\text { method for identi- } \\
\text { fying impacts of an } \\
\text { engineering solu- } \\
\text { tion. } \\
\text { Lists several types } \\
\text { of impacts an engi- } \\
\text { neering solution } \\
\text { might have. }\end{array}$ & $\begin{array}{l}\text { Discusses impacts of } \\
\text { historical or "classi- } \\
\text { cal" engineering } \\
\text { solutions. } \\
\text { Describes certain } \\
\text { principles governing } \\
\text { the types of impacts } \\
\text { that engineering } \\
\text { solutions may cause. } \\
\text { Discusses study } \\
\text { abroad experience }\end{array}$ & $\begin{array}{l}\text { Predicts potential } \\
\text { impacts of a pro- } \\
\text { posed engineering } \\
\text { solution. } \\
\text { Interprets potential } \\
\text { short and long term } \\
\text { impacts of eng- } \\
\text { neering solutions. }\end{array}$ & $\begin{array}{l}\text { Analyzes a specific } \\
\text { engineering "fail- } \\
\text { ure." } \\
\text { Models the role that } \\
\text { unanticipated factors } \\
\text { played in the failure. }\end{array}$ & $\begin{array}{l}\text { Combines knowl- } \\
\text { edge of potential } \\
\text { impacts into the de- } \\
\text { sign and problem } \\
\text { solving processes. }\end{array}$ & $\begin{array}{l}\text { Evaluates (trade- } \\
\text { off) conflicting / } \\
\text { competing values in } \\
\text { order to make in- } \\
\text { formed decisions } \\
\text { about potential im- } \\
\text { pact of an engi- } \\
\text { neering solution. }\end{array}$ & \\
\hline
\end{tabular}

Copyright (c) The University of Pittsburgh, 2000. 


\begin{tabular}{|c|c|c|c|c|c|c|c|}
\hline Definitions & Knowledge & Comprehension & Application & Analysis & Synthesis & Evaluation & Valuation \\
\hline $\begin{array}{l}\text { Outcome Element: } \\
\text { Understanding the } \\
\text { impact of engineer- } \\
\text { ing solutions in a } \\
\text { societal context: } \\
\text { This dimension cov- } \\
\text { ers students' knowl- } \\
\text { edge of societal is- } \\
\text { sues - issues assocl- } \\
\text { ated with the groups } \\
\text { of people and their } \\
\text { beliefs, practices, } \\
\text { and needs. Con- } \\
\text { cepts associated } \\
\text { with culture and } \\
\text { aesthetics fit into } \\
\text { this dimension } \\
\text { Example areas of } \\
\text { impact include, but } \\
\text { are not limited to, } \\
\text { environmental, po- } \\
\text { litical, and eco- } \\
\text { nomic. }\end{array}$ & $\begin{array}{l}\text { Describes the key } \\
\text { features character- } \\
\text { izing an individual's } \\
\text { perspective. } \\
\text { Defines key terms } \\
\text { associated with un- } \\
\text { derstanding a socie- } \\
\text { tal context including } \\
\text { society, culture, and } \\
\text { global society. } \\
\text { Lists the steps in a } \\
\text { method for identi- } \\
\text { fying the societal } \\
\text { impacts of an engi- } \\
\text { neering solution. } \\
\text { States some differ- } \\
\text { ences in needs that } \\
\text { result from diversity } \\
\text { in society } \\
\text { States sorne ways in } \\
\text { which modern soci- } \\
\text { ety is diverse. } \\
\text { Identifies several } \\
\text { facets by which an } \\
\text { engineered solution } \\
\text { inpacts modern so- } \\
\text { ciety (e.g. aesthet- } \\
\text { ics) }\end{array}$ & $\begin{array}{l}\text { Discusses the perti- } \\
\text { nent features of } \\
\text { his/her own per- } \\
\text { spective (beliefs, } \\
\text { practices, etc.). } \\
\text { Distinguishes and } \\
\text { explains perspec- } \\
\text { tives different from } \\
\text { his/her own. } \\
\text { Compares various } \\
\text { practices to identify } \\
\text { similarities and dif- } \\
\text { ferences. } \\
\text { Describes the role } \\
\text { that science, tech- } \\
\text { nology and engi- } \\
\text { neering have played } \\
\text { in the development } \\
\text { of modem society. } \\
\text { Describes how ideas } \\
\text { and customs from } \\
\text { other cultures have } \\
\text { contributed to } \\
\text { his/her discipline } \\
\text { and/or modern soci- } \\
\text { ety. } \\
\text { Describes mile- } \\
\text { stones in the evolu- } \\
\text { tion of the current } \\
\text { "global society." }\end{array}$ & $\begin{array}{l}\text { Uses acquired } \\
\text { knowledge to inter- } \\
\text { pret impacts of an } \\
\text { engineering solution } \\
\text { (i.e., can anticipate } \\
\text { impacts). } \\
\text { Applies knowledge of } \\
\text { the ways in which } \\
\text { ideas and custoros } \\
\text { from other cuitures } \\
\text { contribute to modern } \\
\text { life. } \\
\text { Relates this to the } \\
\text { identification of the } \\
\text { impact of engineering } \\
\text { solutions. } \\
\text { Employs the per- } \\
\text { spective of others } \\
\text { (group, culture) to } \\
\text { identify the impact } \\
\text { of engineering solu- } \\
\text { tions. }\end{array}$ & $\begin{array}{l}\text { Differentiates the } \\
\text { key attributes of a } \\
\text { perspective different } \\
\text { from his/'her own. } \\
\text { Identifies and ana- } \\
\text { lyzes the mecha- } \\
\text { nisms by which al- } \\
\text { ternative practices } \\
\text { achieve the same } \\
\text { goals. } \\
\text { Examines an engi- } \\
\text { neering failure and } \\
\text { analyzes the role } \\
\text { that unanticipated } \\
\text { societal impacts } \\
\text { played in that fail- } \\
\text { ure. }\end{array}$ & $\begin{array}{l}\text { Synthesizes the per- } \\
\text { spectives of multiple } \\
\text { constituents in order } \\
\text { to achieve an ac- } \\
\text { ceptable engineering } \\
\text { solution. } \\
\text { Explains engineer- } \\
\text { ing conflicts in } \\
\text { terms of differences } \\
\text { in perspectives. } \\
\text { Collects knowledge } \\
\text { of that society in } \\
\text { which his/her engi- } \\
\text { neering activity is } \\
\text { situated. }\end{array}$ & $\begin{array}{l}\text { Can critically evalu- } \\
\text { ate the strengths and } \\
\text { weaknesses of } \\
\text { his/her own per- } \\
\text { spective and the per- } \\
\text { spectives of others. } \\
\text { Can assess con- } \\
\text { flicting / competing } \\
\text { perspectives in order } \\
\text { to make informed } \\
\text { decisions about en- } \\
\text { gineering solutions. }\end{array}$ & $\begin{array}{l}\text { Accepts perspec- } \\
\text { tives different from } \\
\text { his/her own. }\end{array}$ \\
\hline
\end{tabular}

Copyright $($ The University of Pittsburgh, 2000. 


\begin{tabular}{|c|c|c|c|c|c|c|c|}
\hline Definitions & Knowledge & Comprehension & Application & Analysis & Synthesis & Evaluation & Valuation \\
\hline $\begin{array}{l}\text { Outcome Element: } \\
\text { Understanding the } \\
\text { impact of engineer- } \\
\text { ing solutions in a } \\
\text { global context } \\
\text { Global - referring to } \\
\text { issues that cross } \\
\text { national bounda- } \\
\text { ries, cultures and/or } \\
\text { societies. } \\
\text { Example areas of } \\
\text { impact include, but } \\
\text { are not limited to, } \\
\text { environmental, po- } \\
\text { litical, and eco- } \\
\text { nomic. } \\
\text { Globat context rep- } \\
\text { resents the under- } \\
\text { standing that stu- } \\
\text { dents need to have } \\
\text { in order to reason } \\
\text { about engineering } \\
\text { solutions crossing } \\
\text { these boundaries. } \\
\text { The key issues here } \\
\text { are the interrela- } \\
\text { tionships among } \\
\text { systems and socie- } \\
\text { ties and the specific } \\
\text { reasoning that must } \\
\text { be included in order } \\
\text { to make informed, } \\
\text { engineering deci- } \\
\text { sions. }\end{array}$ & $\begin{array}{l}\text { States examples of } \\
\text { how nations and } \\
\text { peoples around the } \\
\text { globe are related. } \\
\text { Lists the steps in a } \\
\text { method for identi- } \\
\text { fying impacts of an } \\
\text { engineering solution } \\
\text { that crosses cultures } \\
\text { or societies. } \\
\text { Recognizes the en- } \\
\text { gineering aspects of } \\
\text { a global problem. } \\
\text { States examples } \\
\text { where solving one } \\
\text { problem led to the } \\
\text { development of } \\
\text { other problems (e.g., } \\
\text { antibiotics, why } \\
\text { things bite back). } \\
\text { Lists criteria to be } \\
\text { considered when an } \\
\text { engineering solution } \\
\text { has global aspects } \\
\text { (e.g., language, cul- } \\
\text { tural, safety stan- } \\
\text { dards, political, } \\
\text { etc.). }\end{array}$ & $\begin{array}{l}\text { Discusses how soci- } \\
\text { ety has become } \\
\text { more global. } \\
\text { Describes a particular } \\
\text { situation in which } \\
\text { modern technologies } \\
\text { have had a global im- } \\
\text { pact (e.g. global } \\
\text { warning, chemicals in } \\
\text { environment, tele- } \\
\text { communications). } \\
\text { Classifies the types } \\
\text { of "global" impacts } \\
\text { an engineering so- } \\
\text { lution could have. } \\
\text { Recognizes exam- } \\
\text { ples where solving } \\
\text { one engineering } \\
\text { problem led to the } \\
\text { creation of other } \\
\text { related problems } \\
\text { (e.g., development } \\
\text { of nuclear energy to } \\
\text { reduce dependence } \\
\text { on fossil fuel re- } \\
\text { sulted in increased } \\
\text { nuclear waste; de- } \\
\text { velopment of antibi- } \\
\text { otics to treat bacte- } \\
\text { rial infections re- } \\
\text { sulted in the evolt- } \\
\text { tion of resistant } \\
\text { strains of bacteria). }\end{array}$ & $\begin{array}{l}\text { Predicts potential } \\
\text { global impacts, both } \\
\text { short and long term, } \\
\text { of a proposed engi- } \\
\text { neering solution. } \\
\text { Applies knowiedge } \\
\text { about the interrela- } \\
\text { tionships among } \\
\text { peoples, their cul- } \\
\text { tures and their envi- } \\
\text { ronments to predict } \\
\text { potential impacts of } \\
\text { engineering solu- } \\
\text { tions. } \\
\text { Discovers antici- } \\
\text { pated and unantici- } \\
\text { pated "global" im- } \\
\text { pacts in attempted } \\
\text { and proposed engi- } \\
\text { neering solutions. }\end{array}$ & $\begin{array}{l}\text { Differentiates the } \\
\text { actual impacts of an } \\
\text { engineering solt- } \\
\text { tion. } \\
\text { Infers the relevant } \\
\text { groups of people } \\
\text { and environmental } \\
\text { systems that need to } \\
\text { be considered when } \\
\text { evaluating an engi- } \\
\text { neering solution. }\end{array}$ & $\begin{array}{l}\text { Combines the po- } \\
\text { tential "global" im- } \\
\text { pacts of engineering } \\
\text { solutions to arrive at } \\
\text { an overall effect. } \\
\text { Formulates the en- } \\
\text { gineering design } \\
\text { process to include } \\
\text { the learned knowi- } \\
\text { edge of potential } \\
\text { impacts. }\end{array}$ & $\begin{array}{l}\text { Evaluates potential } \\
\text { "global" impacts in } \\
\text { terms of costs and } \\
\text { benefits. }\end{array}$ & $\begin{array}{l}\text { Respects the his- } \\
\text { torical aspects of } \\
\text { engineering ap- } \\
\text { proaches to "world" } \\
\text { problems and their } \\
\text { impacts. } \\
\text { Actively seeks } \\
\text { knowledge of the } \\
\text { world events which } \\
\text { his/her engineering } \\
\text { activity likely will } \\
\text { be impacted by or } \\
\text { will impact. }\end{array}$ \\
\hline
\end{tabular}




\section{APPENDIX C}

SREB (Southern Regional Education Board) Public Four-Year Institutions

AL Auburn University

AL University of Alabama

AL University of Alabama at Birmingham

AR University of Arkansas, Fayetteville

DL University of Delaware

FL Florida State University

FL University of Florida

FL University of South Florida

GA Georgia State University

GA University of Georgia

KY University of Kentucky

LA Louisiana State University and A\&M College

MD University of Maryland, College Park

MS University of Southern Mississippi

NC North Carolina State University

NC University of North Carolina, Chapel Hill

OK Oklahoma State University, Main Campus

OK University of Oklahoma Norman Campus

SC Clemson University

SC University of South Carolina-Columbia

TN University of Tennessee, Knoxville

TX Texas A \& M University

TX Texas Tech University

TX University of Houston

TX University of North Texas

TX University of Texas at Austin

VA University of Virginia

VA Virginia Tech

WV West Virginia

Universityhttp://www.sreb.org/main/edData/InstCategories/institutions.as 


\section{WestVirginiaUniversity。}

College of Human Resources and Education

\section{APPENDIX D}

November 5, 2008

Dear Engineering Department Chair,

My name is Elisabeth Sanchez and I am currently a Doctoral Student at West Virginia University in the Education Leadership Studies department (EDLS). This communication relates to a research study that I am conducting for my dissertation.

Dr. Donald Lyons, former chair of Mechanical and Aerospace Engineering at West Virginia University is a member of my doctoral committee and is providing the guidance necessary for the completion of my doctoral degree.

As part of my doctoral research program, I have developed a questionnaire aimed at examining how engineering programs are responding to Outcome h, of ABET, as perceived by chairs of engineering departments. As you are aware, Outcome h refers to "the broad education necessary to understand the impact of engineering solutions in a global, economic, environmental, and societal context."

This survey is being sent to Chairpersons of ABET accredited engineering programs at four year institutions belonging to the Southern Regional Education Board group (SREB). Your participation in this research is entirely voluntary and the replies will be treated strictly as confidential and anonymous, in accordance with the Institutional Research Board (IRB) protocol for doctoral research.

Should you have any questions about this letter or research project, please feel free to contact me at esanchez@mix.wvu.edu or through my advisor, Dr. Ernest Goeres (Ed.D. Committee Chair and Principal Investigator) at Ernest.Goeres@mail.wvu.edu. Acknowledgement of this study by West Virginia University's Institutional Review Board is on file.

Sincerely,

Elisabeth Sanchez

Doctoral student in EDLS at WVU

Dr. Ernest Goeres, Chair

Dr. Donald Lyons, Professor,

Mechanical and Aerospace Engineering 
APPENDIX E

\section{Engineering Education ABET-EC2000 Outcome H, and Global}

1. Questionnaire

I am a doctoral student in Higher Education Leadership Studies (EDLS) at West Virginia University and $\mathrm{I}$ am conducting a research about Outcome $h$ of ABET EC2000: "The broad education necessary to understand the impact of engineering solution in a global, economic, environmental, and societal context." This electronic questionnsire should take about 10-15 minutes of your time.

This survey is being sent to Chairpersons of ABET accredited engineering programs at institutions belonging to the Southern Regional Education Board universities (SREB). Your participation is voluntary and you do not have to respond to every item, however, your replies will be treated strictly confidential and anonymous in accordance with the Institutional Research Board (IRB) protocol for doctoral research. Acknowledgment of this study by West Virginia University's Review Board is also on file.

\section{Please, answer the following questions about your institution:}

a) Name of Institution:

b) College and

Department:

\section{Please, answer the following questions related to your position and Program:}

c) Your job title:

d) Number of full-time undergraduate students in your Program:

e) Number of full-time faculty members in your Program:

f) (Optional) e-mail address to receive results of survey?

\section{Based on undergraduate students' demographics of your Department, please answer the following questions:}

9) On average, what percent of students, per year, seek study abroad with academic credits iN engineering?

h) On average, how many professors travel abroad, per year. WIrH students for instrtuctional purposes?

i) On average, how many international exchange students do you host in your Department, per year? 


\section{Engineering Education ABET-EC2000 Outcome $\mathrm{H}$, and Global}

4. In the following set, five "Global Competencies" are stated across the table and 10 questions are posed in which we ask you too rate according to the following rubric:

\section{1= Not at all; $2=$ Sometimes; $3=$ Often; $4=$ Always $/$ High} (from lowest negative to highest positive)

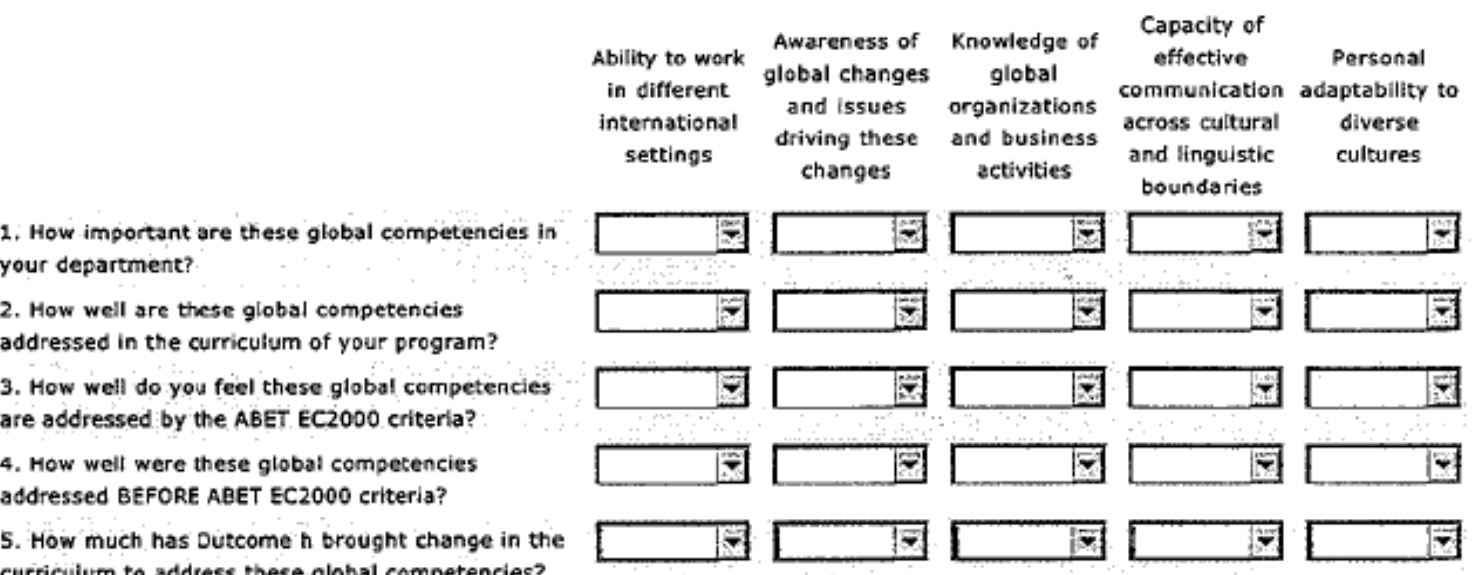

\section{Continuation of preceding question...}

\section{1= Not at all; $2=$ Sometimes; $3=$ Often; $4=$ Always $/$ High}

(from lowest negative to highest positive)

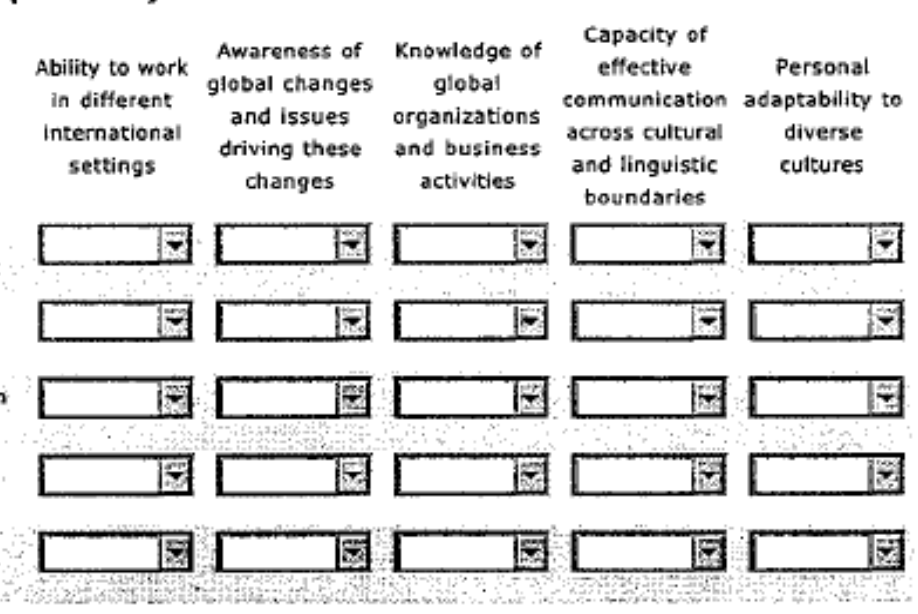

6. How well have your graduates acquired these competencies AFTER EC2000?

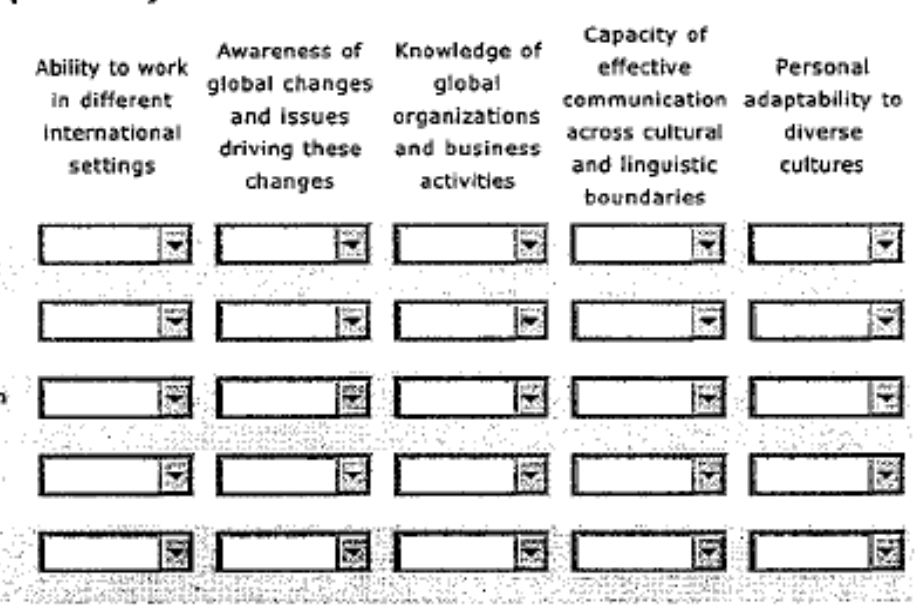

7. How well did ycur graduates acquired these competencies BEFORE EC2000?

8. How well does your documentation of Outcome h demonstrates these competencles?

9. How well do international experiences promote attainment of these competencies?

10. How well these competencies can be attained without international experiences?

\section{Are there any specific courses in your Program that require international travel?}
Not at all
$\bigcirc$ one course
$\bigcirc$ Several courses 


\section{Engineering Education ABET-EC2000 Outcome $\mathrm{H}$, and Global}

7. What do you think would be the best way to prepare engineering students to develop global competencies?

(Please, select ONLY one)

1. Through selected Humanities and

Social Sciences courses

2. By adding topics to current

engineering courses

3. Through study abroad programs in engineering

8. How is your Department (PRIMARILY) preparing engineering students to develop global competencies?

(Please, select ONLY one)

1. Through selected Humanities and Social Sciences courses

2. By adding topics to current engineering courses
3. Through study abroad programs in engineering

9. Piease, click one choice for each statement.

14. We have not done anything differently, BEFORE
and AfTER EC2000, regarding Outcome $\mathrm{h}$.
15. About Outcome $\mathrm{h}$, we have improved the
documentation on what we have been doing all
along.
16. We made some changes IN SOME courses to
comply with Outcome h.
17. We made some changes To our curriculum to
comply with Outcome h.
18. We are looking into the curriculum to modify
some required courses to add international
experiences to comply with Outcome h.
19. It is very important that our engineering
graduates acquire global competencies to comply

graduates acquire global competencies to comply with Outcome h.

10. Please, feel free to add comments ...

THANK YOU VERY MUCH FOR YOUR HELP!

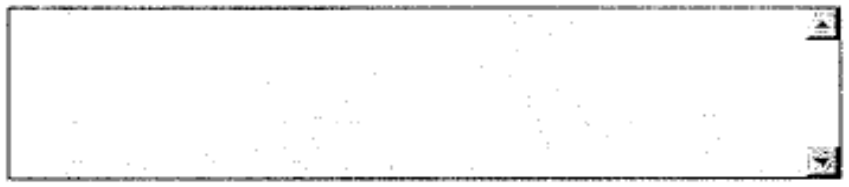

Elisabeth Sanchez (esanchez@mix.wru.edu)

West Virginia University

P.O.Box 6106

Morgantown, WV, 26506

If you have questions please call (304) 599-1567, Fax (304) 293- 6689 


\section{APPENDIX F}

\section{One-Way ANOVA - Global Competency Attention \#1}

Table 6

Global Competency Attention \#1 - Ability to work in different international settings ANOVA

\begin{tabular}{|c|c|c|c|c|c|}
\hline & Sum of Squares & df & Mean Square & $\mathrm{F}$ & Sig. \\
\hline Between Groups & .202 & 2 & .101 & .256 & .776 \\
Within Groups & 16.598 & 42 & .395 & & \\
Total & 16.800 & 44 & & & \\
\hline
\end{tabular}

\section{Multiple Comparisons - Bonferroni}

\begin{tabular}{|c|c|c|c|c|c|c|}
\hline \multirow{2}{*}{$\begin{array}{c}\text { (I) Developing } \\
\text { global } \\
\text { competencies }\end{array}$} & \multirow{2}{*}{$\begin{array}{l}\text { (J) Developing global } \\
\text { competencies }\end{array}$} & \multirow{2}{*}{$\begin{array}{c}\text { Mean } \\
\text { Difference (I- } \\
\mathrm{J})\end{array}$} & \multirow[t]{2}{*}{ Std. Error } & \multirow[t]{2}{*}{ Sig. } & \multicolumn{2}{|c|}{ 95\% Confidence Interval } \\
\hline & & & & & Lower Bound & Upper Bound \\
\hline $\begin{array}{l}\text { Through } \\
\text { selected } \\
\text { Humanities and } \\
\text { Social Sciences } \\
\text { courses }\end{array}$ & $\begin{array}{c}\text { By adding topics to } \\
\text { current engineering } \\
\text { courses } \\
\text { Through Study Abroad } \\
\text { programs in } \\
\text { engineering }\end{array}$ & -.143 & .226 & 1.000 & -.71 & .42 \\
\hline $\begin{array}{l}\text { By adding topics } \\
\text { to current } \\
\text { engineering } \\
\text { courses }\end{array}$ & $\begin{array}{c}\text { Through selected } \\
\text { Humanities and Social } \\
\text { Sciences courses } \\
\text { Through Study Abroad } \\
\text { programs in } \\
\text { engineering }\end{array}$ & .143 & .226 & 1.000 & -.42 & .71 \\
\hline $\begin{array}{c}\text { Through Study } \\
\text { Abroad } \\
\text { programs in } \\
\text { engineering }\end{array}$ & $\begin{array}{l}\text { Through selected } \\
\text { Humanities and Social } \\
\text { Sciences courses } \\
\text { By adding topics to } \\
\text { current engineering } \\
\text { courses }\end{array}$ & .038 & .292 & 1.000 & -.55 & .91 \\
\hline
\end{tabular}




\section{APPENDIX G}

\section{One-Way ANOVA - Global Competency Attention \#3}

Table 7

Global Competency Attention \#3 - Knowledge of global organizations and business activities ANOVA

\begin{tabular}{|c|c|c|c|c|c|}
\hline & Sum of Squares & df & Mean Square & F & Sig. \\
\hline Between Groups & 3.910 & 2 & 1.955 & 4.256 & .021 \\
Within Groups & 19.290 & 42 & .459 & & \\
Total & 23.200 & 44 & & & \\
\hline
\end{tabular}

\section{Multiple Comparisons - Bonferroni}

\begin{tabular}{|c|c|c|c|c|c|c|}
\hline \multirow{2}{*}{$\begin{array}{c}\text { (I) Developing } \\
\text { global } \\
\text { competencies }\end{array}$} & \multirow{2}{*}{$\begin{array}{c}\text { (J) Developing } \\
\text { global competencies }\end{array}$} & \multirow{2}{*}{$\begin{array}{c}\text { Mean } \\
\text { Difference (I-J) }\end{array}$} & \multirow[t]{2}{*}{ Std. Error } & \multirow[t]{2}{*}{ Sig. } & \multicolumn{2}{|c|}{ 95\% Confidence Interval } \\
\hline & & & & & Lower Bound & Upper Bound \\
\hline $\begin{array}{c}\text { Through } \\
\text { selected } \\
\text { Humanities and } \\
\text { Social } \\
\text { Sciences } \\
\text { courses }\end{array}$ & $\begin{array}{l}\text { By adding topics to } \\
\text { current engineering } \\
\text { courses } \\
\text { Through Study } \\
\text { Abroad programs in } \\
\text { engineering }\end{array}$ & -.566 & .244 & 1.000 & -1.17 & .04 \\
\hline $\begin{array}{l}\text { By adding } \\
\text { topics to } \\
\text { current } \\
\text { engineering } \\
\text { courses }\end{array}$ & $\begin{array}{l}\text { Through selected } \\
\text { Humanities and } \\
\text { Social Sciences } \\
\text { courses } \\
\text { Through Study } \\
\text { Abroad programs in } \\
\text { engineering }\end{array}$ & .566 & .244 & .075 & -.04 & 1.32 \\
\hline $\begin{array}{l}\text { Through Study } \\
\text { Abroad } \\
\text { programs in } \\
\text { engineering }\end{array}$ & $\begin{array}{l}\text { Through selected } \\
\text { Humanities and } \\
\text { Social Sciences } \\
\text { courses } \\
\text { By adding topics to } \\
\text { current engineering } \\
\text { courses }\end{array}$ & $\begin{array}{r}-.068 \\
\\
-.635\end{array}$ & .315 & 1.000 & -.85 & .05 \\
\hline
\end{tabular}


Table 8

\section{APPENDIX H}

Global Competency Attention \#4 - Capacity of effective communication across cultural and linguistic boundaries

ANOVA

\begin{tabular}{|c|c|c|c|c|c|}
\hline & Sum of Squares & $\mathrm{df}$ & Mean Square & $\mathrm{F}$ & Sig. \\
\hline Between Groups & .796 & 2 & .398 & .665 & .519 \\
Within Groups & 25.115 & 42 & .598 & & \\
Total & 25.911 & 44 & & \\
\hline
\end{tabular}

\section{Multiple Comparisons - Bonferroni}

\begin{tabular}{|c|c|c|c|c|c|c|}
\hline \multirow{2}{*}{$\begin{array}{c}\text { (I) Developing } \\
\text { global } \\
\text { competencies }\end{array}$} & \multirow{2}{*}{$\begin{array}{l}\text { (J) Developing global } \\
\text { competencies }\end{array}$} & \multirow{2}{*}{$\begin{array}{c}\text { Mean } \\
\text { Difference } \\
(\mathrm{I}-\mathrm{J})\end{array}$} & \multirow[t]{2}{*}{ Std. Error } & \multirow[t]{2}{*}{ Sig. } & \multicolumn{2}{|c|}{ 95\% Confidence Interval } \\
\hline & & & & & Lower Bound & Upper Bound \\
\hline $\begin{array}{l}\text { Through selected } \\
\text { Humanities and } \\
\text { Social Sciences } \\
\text { courses }\end{array}$ & $\begin{array}{l}\text { By adding topics to } \\
\text { current engineering } \\
\text { courses } \\
\text { Through Study } \\
\text { Abroad programs in } \\
\text { engineering }\end{array}$ & -.269 & .278 & 1.000 & -.96 & .42 \\
\hline $\begin{array}{l}\text { By adding topics } \\
\text { to current } \\
\text { engineering } \\
\text { courses } \\
\end{array}$ & $\begin{array}{l}\text { Through selected } \\
\text { Humanities and Social } \\
\text { Sciences courses } \\
\text { Through Study } \\
\text { Abroad programs in } \\
\text { engineering }\end{array}$ & .269 & .278 & 1.000 & -.42 & .96 \\
\hline $\begin{array}{l}\text { Through Study } \\
\text { Abroad programs } \\
\text { in engineering }\end{array}$ & $\begin{array}{l}\text { Through selected } \\
\text { Humanities and Social } \\
\text { Sciences courses } \\
\text { By adding topics to } \\
\text { current engineering } \\
\text { courses }\end{array}$ & -.269 & .313 & 1.000 & -1.05 & .51 \\
\hline
\end{tabular}




\section{APPENDIX I}

\section{One-Way ANOVA - Global Competency Performance \#1}

Table 9

Global Competency Performance \#1 - Ability to work in different international setting ANOVA

\begin{tabular}{|l|l|l|l|l|l|}
\hline & Sum of Squares & df & Mean Square & F & Sig. \\
\hline Between Groups & 145 & 2 & .072 & .177 & .839 \\
Within Groups & 16.367 & 40 & .409 & & \\
Total & 16.512 & 42 & & & \\
\hline
\end{tabular}

\section{Multiple Comparisons - Bonferroni}

\begin{tabular}{|c|c|c|c|c|c|c|}
\hline \multirow[b]{2}{*}{$\begin{array}{l}\text { (I) Developing } \\
\text { competencies }\end{array}$} & \multirow[b]{2}{*}{$\begin{array}{c}\text { global (J) Developing global } \\
\text { competencies }\end{array}$} & \multirow[b]{2}{*}{$\begin{array}{l}\text { Mean Difference } \\
(\mathrm{I}-\mathrm{J})\end{array}$} & \multirow[b]{2}{*}{ Std. Error } & \multirow[b]{2}{*}{ Sig. } & \multicolumn{2}{|c|}{ 95\% Confidence Interval } \\
\hline & & & & & Lower Bound & $\begin{array}{l}\text { Upper } \\
\text { Bound }\end{array}$ \\
\hline $\begin{array}{l}\text { Through selectec } \\
\text { Humanities and Socia } \\
\text { Sciences courses }\end{array}$ & $\begin{array}{l}\text { By adding topics to } \\
\text { courrent engineering } \\
\text { courses } \\
\text { Through Study Abroad } \\
\text { programs in engineering }\end{array}$ & $\begin{array}{l}-.092 \\
-.186\end{array}$ & .238 & $x^{2}$ & -.69 & .50 \\
\hline \multirow[t]{2}{*}{$\begin{array}{l}\text { By adding topics to curren } \\
\text { engineering courses }\end{array}$} & $\begin{array}{l}\text { Through selected } \\
\text { Humanities and Social } \\
\text { Sciences courses }\end{array}$ & .092 & .238 & 1.000 & -.50 & .69 \\
\hline & $\begin{array}{l}\text { Through Study Abroad } \\
\text { programs in engineering }\end{array}$ & -.093 & .272 & 1.000 & -.77 & .59 \\
\hline \multirow[t]{2}{*}{$\begin{array}{l}\text { Through Study Abroac } \\
\text { programs in engineering }\end{array}$} & $\begin{array}{l}\text { Through selected } \\
\text { Humanities and Social } \\
\text { Sciences courses }\end{array}$ & .186 & .315 & 1.000 & -.60 & .97 \\
\hline & $\begin{array}{l}\text { By adding topics to } \\
\text { current engineering } \\
\text { courses }\end{array}$ & .093 & .272 & 1.000 & -.59 & .77 \\
\hline
\end{tabular}




\section{APPENDIX J}

One-Way ANOVA - Global Competency Performance \#2

Table10

Global Competency Performance \#2 - Awareness of global changes and issues driving these changes

ANOVA

\begin{tabular}{|c|c|c|c|c|c|}
\hline & Sum of Squares & df & Mean Square & F & Sig. \\
\hline $\begin{array}{c}\text { Between } \\
\text { Groups }\end{array}$ & .337 & 2 & .168 & .368 & .694 \\
Within Groups & 18.268 & 40 & .457 & & \\
Total & 18.605 & 42 & & & \\
\hline
\end{tabular}

\section{Multiple Comparisons - Bonferroni}

\begin{tabular}{|c|c|c|c|c|c|c|}
\hline \multirow{2}{*}{$\begin{array}{c}\text { (I) Developing } \\
\text { global } \\
\text { competencies }\end{array}$} & \multirow{2}{*}{$\begin{array}{l}\text { (J) Developing global } \\
\text { competencies }\end{array}$} & \multirow{2}{*}{$\begin{array}{c}\text { Mean Difference } \\
(I-J)\end{array}$} & \multirow[t]{2}{*}{ Std. Error } & \multirow[t]{2}{*}{ Sig. } & \multicolumn{2}{|c|}{ 95\% Confidence Interval } \\
\hline & & & & & Lower Bound & $\begin{array}{l}\text { Upper } \\
\text { Bound }\end{array}$ \\
\hline $\begin{array}{l}\text { Through selected } \\
\text { Humanities and } \\
\text { Social Sciences } \\
\text { courses }\end{array}$ & $\begin{array}{c}\text { By adding topics to current } \\
\text { engineering courses } \\
\text { Through Study Abroad } \\
\text { programs in engineering }\end{array}$ & $\begin{array}{l}-.215 \\
-.171\end{array}$ & .251 & 1.000 & -.84 & .41 \\
\hline $\begin{array}{l}\text { By adding topics to } \\
\text { current engineering } \\
\text { courses }\end{array}$ & $\begin{array}{c}\text { Through selected } \\
\text { Humanities and Social } \\
\text { Sciences courses } \\
\text { Through Study Abroad } \\
\text { programs in engineering }\end{array}$ & $\begin{array}{l}.215 \\
.044\end{array}$ & .251 & $\begin{array}{l}1.000 \\
1.000\end{array}$ & -.41 & $\begin{array}{l}.84 \\
.76\end{array}$ \\
\hline $\begin{array}{l}\text { Through Study } \\
\text { Abroad programs in } \\
\text { engineering }\end{array}$ & $\begin{array}{c}\text { Through selected } \\
\text { Humanities and Social } \\
\text { Sciences courses } \\
\text { By adding topics to current } \\
\text { engineering courses }\end{array}$ & -.044 & .288 & 1.000 & -.76 & .68 \\
\hline
\end{tabular}




\section{APPENDIX K \\ One-Way ANOVA - Global Competency Performance \#3}

Table 11

Global Competency Performance \#3 - Knowledge of global organizations and business activities ANOVA

\begin{tabular}{|c|c|c|c|c|c|}
\hline & Sum of Squares & df & Mean Square & $\mathrm{F}$ & Sig. \\
\hline Between Groups & 1.667 & 2 & .834 & 1.659 & .203 \\
Within Groups & 20.100 & 40 & .503 & & \\
Total & 21.767 & 42 & & \\
\hline
\end{tabular}

\section{Multiple Comparisons - Bonferroni}

\begin{tabular}{|c|c|c|c|c|c|c|}
\hline \multirow{2}{*}{$\begin{array}{l}\text { (I) Developing global } \\
\text { competencies }\end{array}$} & \multirow{2}{*}{$\begin{array}{l}\text { (J) Developing global } \\
\text { competencies }\end{array}$} & \multirow{2}{*}{$\begin{array}{c}\text { Mean } \\
\text { Difference (I- } \\
\mathrm{J})\end{array}$} & \multirow[t]{2}{*}{ Std. Error } & \multirow[t]{2}{*}{ Sig. } & \multicolumn{2}{|c|}{ 95\% Confidence Interval } \\
\hline & & & & & Lower Bound & Upper Bound \\
\hline $\begin{array}{l}\text { Through selected Humanities } \\
\text { and Social Sciences courses }\end{array}$ & $\begin{array}{c}\text { By adding topics to } \\
\text { current engineering } \\
\text { courses } \\
\text { Through Study Abroad } \\
\text { programs in } \\
\text { engineering }\end{array}$ & $\begin{array}{l}-.300 \\
.200\end{array}$ & .264 & .786 & -.96 & .36 \\
\hline $\begin{array}{l}\text { By adding topics to current } \\
\text { engineering courses }\end{array}$ & $\begin{array}{c}\text { Through selected } \\
\text { Humanities and Social } \\
\text { Sciences courses } \\
\text { Through Study Abroad } \\
\text { programs in } \\
\text { engineering }\end{array}$ & .300 & .264 & .786 & -.36 & .96 \\
\hline $\begin{array}{l}\text { Through Study Abroad } \\
\text { programs in engineering }\end{array}$ & $\begin{array}{l}\text { Through selected } \\
\text { Humanities and Social } \\
\text { Sciences courses } \\
\text { By adding topics to } \\
\text { current engineering } \\
\text { courses }\end{array}$ & -.500 & .349 & 1.000 & $\begin{array}{l}-1.07 \\
-1.25\end{array}$ & .25 \\
\hline
\end{tabular}




\section{APPENDIX L \\ One-Way ANOVA - Global Competency Performance \#4}

Table 12

Global Competency Performance\#4 - Capacity of effective communication across cultural and linguistic boundaries

ANOVA

\begin{tabular}{|c|c|c|c|c|c|}
\hline & Sum of Squares & df & Mean Square & F & Sig. \\
\hline Between Groups & 3.251 & 2 & 1.626 & 3.352 & .045 \\
Within Groups & 19.400 & 40 & .485 & & \\
Total & 22.651 & 42 & & & \\
\hline
\end{tabular}

Multiple Comparisons - Bonferroni

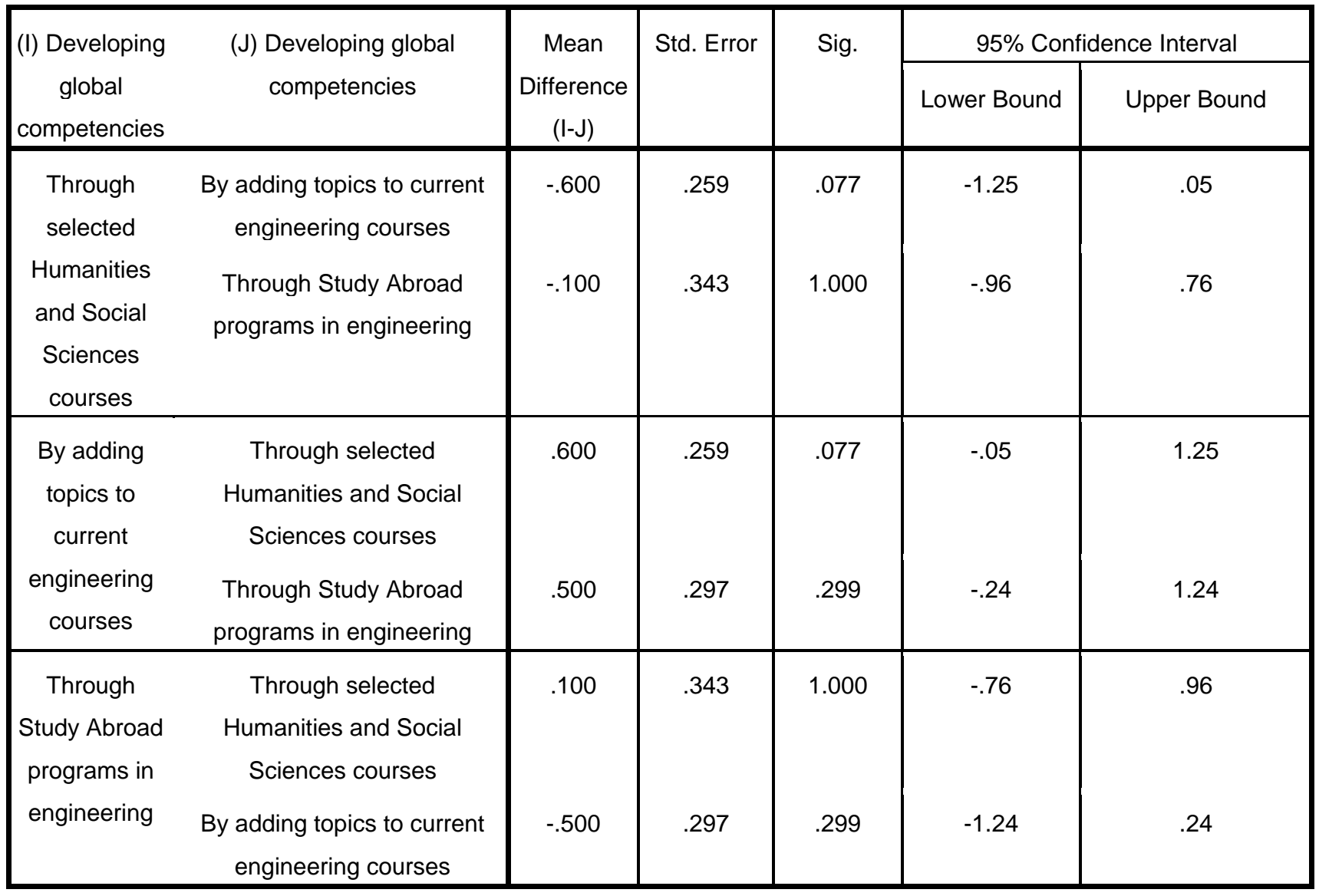




\section{APPENDIX M}

One-Way ANOVA - Global Competency Performance \#5

Table 13

Global Competency Performance \#5 - Awareness of global changes and issues driving these changes

ANOVA

\begin{tabular}{|l|l|l|l|l|l|}
\hline & Sum of Squares & $d f$ & Mean Square & F & Sig. \\
\hline Between Groups & 2.963 & 2 & 1.481 & 2.738 & .077 \\
\hline Within Groups & 21.642 & 40 & .541 & & \\
\hline Total & 24.605 & 42 & & & \\
\hline
\end{tabular}

Multiple Comparisons - Bonferroni

\begin{tabular}{|c|c|c|c|c|c|c|}
\hline \multirow[t]{2}{*}{$\begin{array}{l}\text { (I) Developing global } \\
\text { competencies }\end{array}$} & \multirow[t]{2}{*}{ (J) Developing global competencies } & \multirow{2}{*}{$\begin{array}{c}\text { Mean } \\
\text { Difference } \\
(I-J)\end{array}$} & \multirow[t]{2}{*}{ Std. Error } & \multirow[t]{2}{*}{ Sig. } & \multicolumn{2}{|c|}{$\begin{array}{l}\text { 95\% Confidence } \\
\text { Interval }\end{array}$} \\
\hline & & & & & $\begin{array}{l}\text { Lower } \\
\text { Bound }\end{array}$ & $\begin{array}{l}\text { Upper } \\
\text { Bound }\end{array}$ \\
\hline \multirow{2}{*}{$\begin{array}{l}\text { Through selected } \\
\text { Humanities and Social } \\
\text { Sciences courses }\end{array}$} & $\begin{array}{c}\text { By adding topics to current } \\
\text { engineering courses }\end{array}$ & -.554 & .274 & .149 & -1.24 & .13 \\
\hline & $\begin{array}{c}\text { Through Study Abroad programs in } \\
\text { engineering }\end{array}$ & -.043 & .362 & 1.000 & -.95 & .86 \\
\hline \multirow{2}{*}{$\begin{array}{l}\text { By adding topics to } \\
\text { current engineering } \\
\text { courses }\end{array}$} & $\begin{array}{l}\text { Through selected Humanities and } \\
\text { Social Sciences courses }\end{array}$ & .554 & .274 & .149 & -.13 & 1.24 \\
\hline & $\begin{array}{c}\text { Through Study Abroad programs in } \\
\text { engineering }\end{array}$ & .511 & .313 & .332 & -.27 & 1.29 \\
\hline \multirow{2}{*}{$\begin{array}{c}\text { Through Study Abroad } \\
\text { programs in } \\
\text { engineering }\end{array}$} & $\begin{array}{l}\text { Through selected Humanities and } \\
\text { Social Sciences courses }\end{array}$ & .043 & .362 & 1.000 & -.86 & .95 \\
\hline & $\begin{array}{l}\text { By adding topics to current } \\
\text { engineering courses }\end{array}$ & -.511 & .313 & .332 & -1.29 & .27 \\
\hline
\end{tabular}




\section{APPENDIX N}

\section{Multiple Regressions - Global Competency \#1}

Table 14

Multiple regression global competency \#1 - Model Summary, ANOVA ${ }^{\mathrm{b}}$ and Coefficients

Model Summary

\begin{tabular}{|l|r|r|r|r|}
\hline Model & $\mathrm{R}$ & $\mathrm{R}$ Square & Adjusted R Square & Std. Error of the Estimate \\
\hline 1 & $.442^{\mathrm{a}}$ & .195 & .083 & .607 \\
\hline
\end{tabular}

a. Predictors: (Constant), 2) Global Competency \#5 - Personal adaptability to diverse cultures, 2) Global Competency \#3 Knowledge of global organizations and business activities, 2) Global Competency \#1 - Ability to work in different international settings, 2) Global Competency \#2 - Awareness of global changes and issues driving these changes, 2) Global Competency \#4 - Capacity of effective communication across cultural and linguistic boundaries

\begin{tabular}{|c|c|c|c|c|c|c|}
\hline \multicolumn{7}{|c|}{ ANOVA $^{b}$} \\
\hline & & Sum of Squares & $d f$ & Mean Square & $\mathrm{F}$ & Sig. \\
\hline 1 & $\begin{array}{l}\text { Regression } \\
\text { Residual } \\
\text { Total }\end{array}$ & $\begin{array}{c}3.214 \\
13.263 \\
16.476\end{array}$ & $\begin{array}{r}5 \\
36 \\
41\end{array}$ & $\begin{array}{l}.643 \\
.368\end{array}$ & 1.745 & $.149^{a}$ \\
\hline
\end{tabular}

a. Predictors: (Constant), 2) Global Competency \#5 - Personal adaptability to diverse cultures, 2) Global Competency \#3 Knowledge of global organizations and business activities, 2) Global Competency \#1 - Ability to work in different international settings, 2) Global Competency \#2 - Awareness of global changes and issues driving these changes, 2) Global Competency \#4 - Capacity of effective communication across cultural and linguistic boundaries b. Dependent Variable: 6) Global Competency \#1 - Ability to work in different international setting 


\section{Coefficients $^{\mathrm{a}}$}

\begin{tabular}{|c|c|c|c|c|c|c|}
\hline \multirow[b]{2}{*}{ Mod } & & \multicolumn{2}{|c|}{ Unstandardized Coefficients } & \multirow{2}{*}{$\begin{array}{c}\text { Standardized } \\
\text { Coefficients }\end{array}$} & \multirow[b]{2}{*}{$\mathrm{t}$} & \multirow[b]{2}{*}{ Sig. } \\
\hline & & B & Std. Error & & & \\
\hline \multirow[t]{20}{*}{1} & (Constant) & 1.155 & .407 & & 2.838 & .007 \\
\hline & 2) Global Competency \#1 - & .394 & .199 & .387 & 1.982 & .055 \\
\hline & Ability to work in different & & & & & \\
\hline & international settings & & & & & \\
\hline & 2) Global Competency \#2 - & .133 & .186 & .140 & .716 & .479 \\
\hline & Awareness of global changes & & & & & \\
\hline & and issues driving these & & & & & \\
\hline & changes & & & & & \\
\hline & 2) Global Competency \#3 - & .065 & .159 & .077 & .406 & .687 \\
\hline & Knowledge of global & & & & & \\
\hline & organizations and business & & & & & \\
\hline & activities & & & & & \\
\hline & 2) Global Competency \#4 - & .070 & .168 & .083 & .417 & .679 \\
\hline & Capacity of effective & & & & & \\
\hline & communication across & & & & & \\
\hline & cultural and linguistic & & & & & \\
\hline & boundaries & & & & & \\
\hline & 2) Global Competency \#5 - & -.163 & .162 & -.211 & -1.003 & .323 \\
\hline & Personal adaptability to & & & & & \\
\hline & diverse cultures & & & & & \\
\hline
\end{tabular}

a. Dependent Variable: 6) Global Competency \#1 - Ability to work in different international setting 


\section{APPENDIX O \\ Multiple Regressions - Global Competency \#3}

Table 15

Multiple regressions global competency \#3 - Model Summary, ANOVA ${ }^{\mathrm{b}}$ and Coefficient

Model Summary

\begin{tabular}{|l|r|r|r|r|}
\hline Model & \multicolumn{1}{|c|}{$\mathrm{R}$} & R Square & \multicolumn{1}{c|}{$\begin{array}{c}\text { Adjusted R } \\
\text { Square }\end{array}$} & \multicolumn{1}{c|}{ Std. Error of the Estimate } \\
\hline 1 & $.532^{\mathrm{a}}$ & .283 & .183 & \\
\hline
\end{tabular}

a. Predictors: (Constant), 2) Global Competency \#5 - Personal adaptability to diverse cultures, 2) Global Competency \#3 Knowledge of global organizations and business activities, 2) Global Competency \#1 - Ability to work in different international settings, 2) Global Competency \#2 - Awareness of global changes and issues driving these changes, 2) Global Competency \#4 - Capacity of effective communication across cultural and linguistic boundaries

\begin{tabular}{|ll|r|r|r|r|r|}
\hline \multicolumn{1}{|l|}{ Model $^{2}$} & Sum of Squares & df & Mean Square & \multicolumn{1}{c|}{ F } & Sig. \\
\hline 1 & Regression & 6.116 & 5 & 1.223 & 2.836 & $.029^{\mathrm{a}}$ \\
& Residual & 15.527 & 36 & .431 & & \\
& 21.643 & 41 & & & \\
\hline
\end{tabular}

a. Predictors: (Constant), 2) Global Competency \#5 - Personal adaptability to diverse cultures, 2) Global Competency \#3 Knowledge of global organizations and business activities, 2) Global Competency \#1 - Ability to work in different international settings, 2) Global Competency \#2 - Awareness of global changes and issues driving these changes, 2) Global Competency \#4 - Capacity of effective communication across cultural and linguistic boundaries b. Dependent Variable: 6) Global Competency \#3 - Knowledge of global organizations and business activities 


\section{Coefficients $^{\mathrm{a}}$}

\begin{tabular}{|c|c|c|c|c|c|c|}
\hline \multirow[b]{2}{*}{ Mod } & & \multicolumn{2}{|c|}{ Unstandardized Coefficients } & \multirow{2}{*}{$\begin{array}{c}\begin{array}{c}\text { Standardized } \\
\text { Coefficients }\end{array} \\
\text { Beta }\end{array}$} & \multirow[b]{2}{*}{$\mathrm{t}$} & \multirow[b]{2}{*}{ Sig. } \\
\hline & & B & Std. Error & & & \\
\hline \multirow[t]{20}{*}{1} & (Constant) & 1.421 & .440 & & 3.226 & .003 \\
\hline & 2) Global Competency \#1 - & .203 & .215 & .174 & .943 & .352 \\
\hline & Ability to work in different & & & & & \\
\hline & international settings & & & & & \\
\hline & 2) Global Competency \#2 - & .023 & .201 & .021 & .114 & .910 \\
\hline & Awareness of global changes & & & & & \\
\hline & and issues driving these & & & & & \\
\hline & changes & & & & & \\
\hline & 2) Global Competency \#3 - & .539 & .172 & .557 & 3.122 & .004 \\
\hline & Knowledge of global & & & & & \\
\hline & organizations and business & & & & & \\
\hline & activities & & & & & \\
\hline & 2) Global Competency \#4 - & -.100 & .182 & -.104 & -.551 & .585 \\
\hline & Capacity of effective & & & & & \\
\hline & communication across & & & & & \\
\hline & cultural and linguistic & & & & & \\
\hline & boundaries & & & & & \\
\hline & 2) Global Competency \#5 - & -.206 & .175 & -.234 & -1.177 & .247 \\
\hline & Personal adaptability to & & & & & \\
\hline & diverse cultures & & & & & \\
\hline
\end{tabular}

a. Dependent Variable: 6) Global Competency \#3 - Knowledge of global organizations and business activities 


\section{APPENDIX P}

\section{Multiple Regressions - Global Competency \#4}

Table 16

Multiple regressions global competency \#4 - Model Summary, ANOVA ${ }^{\mathrm{b}}$ and Coefficients ${ }^{a}$

Model Summary

\begin{tabular}{|l|r|r|r|r|}
\hline Model & $\mathrm{R}$ & $\mathrm{R}$ Square & \multicolumn{1}{c|}{$\begin{array}{c}\text { Adjusted R } \\
\text { Square }\end{array}$} & Std. Error of the Estimate \\
\hline 1 & $.610^{\mathrm{a}}$ & .372 & .285 & .627 \\
\hline
\end{tabular}

a. Predictors: (Constant), 2) Global Competency \#5 - Personal adaptability to diverse cultures, 2) Global Competency \#3 Knowledge of global organizations and business activities, 2) Global Competency \#1 - Ability to work in different international settings, 2) Global Competency \#2 - Awareness of global changes and issues driving these changes, 2) Global Competency \#4 - Capacity of effective communication across cultural and linguistic boundaries

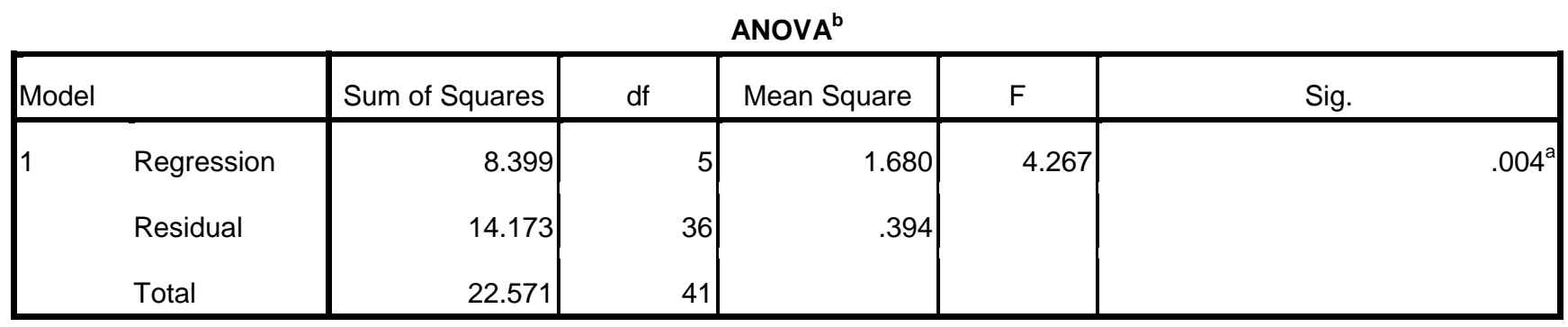

a. Predictors: (Constant), 2) Global Competency \#5 - Personal adaptability to diverse cultures, 2) Global Competency \#3 Knowledge of global organizations and business activities, 2) Global Competency \#1 - Ability to work in different international settings, 2) Global Competency \#2 - Awareness of global changes and issues driving these changes, 2) Global Competency \#4 - Capacity of effective communication across cultural and linguistic boundaries

b. Dependent Variable: 6) Global Competency \#4 - Capacity of effective communication across cultural and linguistic boundaries 


\section{Coefficients $^{\mathrm{a}}$}

\begin{tabular}{|c|c|c|c|c|c|c|}
\hline \multirow[b]{2}{*}{ Mod } & & \multicolumn{2}{|c|}{ Unstandardized Coefficients } & \multirow{2}{*}{$\begin{array}{c}\begin{array}{c}\text { Standardized } \\
\text { Coefficients }\end{array} \\
\text { Beta }\end{array}$} & \multirow[b]{2}{*}{$\mathrm{t}$} & \multirow[b]{2}{*}{ Sig. } \\
\hline & & B & Std. Error & & & \\
\hline \multirow[t]{20}{*}{1} & (Constant) & .667 & .421 & & 1.585 & .122 \\
\hline & 2) Global Competency \#1 - & .044 & .206 & .037 & .216 & .830 \\
\hline & Ability to work in different & & & & & \\
\hline & international settings & & & & & \\
\hline & 2) Global Competency \#2 - & .030 & .192 & .027 & .157 & .876 \\
\hline & Awareness of global changes & & & & & \\
\hline & and issues driving these & & & & & \\
\hline & changes & & & & & \\
\hline & 2) Global Competency \#3 - & .194 & .165 & .196 & 1.177 & .247 \\
\hline & Knowledge of global & & & & & \\
\hline & organizations and business & & & & & \\
\hline & activities & & & & & \\
\hline & 2) Global Competency \#4 - & .319 & .174 & .322 & 1.832 & .075 \\
\hline & Capacity of effective & & & & & \\
\hline & communication across & & & & & \\
\hline & cultural and linguistic & & & & & \\
\hline & boundaries & & & & & \\
\hline & 2) Global Competency \#5 - & .156 & .168 & .173 & .929 & .359 \\
\hline & Personal adaptability to & & & & & \\
\hline & diverse cultures & & & & & \\
\hline
\end{tabular}

a. Dependent Variable: 6) Global Competency \#4 - Capacity of effective communication across cultural and linguistic boundaries 


\section{APPENDIX Q \\ Multiple Regressions - Global Competency \#5}

Table 17

Multiple regressions global competency $\# 5$ - Model Summary, ANOVA $^{\mathrm{b}}$ and Coefficients ${ }^{a}$

Model Summary

\begin{tabular}{|l|r|r|r|r|}
\hline Model & R & R Square & \multicolumn{1}{c|}{$\begin{array}{c}\text { Adjusted R } \\
\text { Square }\end{array}$} & Std. Error of the Estimate \\
\hline 1 & $.700^{\mathrm{a}}$ & .490 & .420 & .588 \\
\hline
\end{tabular}

a. Predictors: (Constant), 2) Global Competency \#5 - Personal adaptability to diverse cultures, 2) Global Competency \#3 Knowledge of global organizations and business activities, 2) Global Competency \#1 - Ability to work in different international settings, 2) Global Competency \#2 - Awareness of global changes and issues driving these changes, 2) Global Competency \#4 - Capacity of effective communication across cultural and linguistic boundaries

ANOVA $^{b}$

\begin{tabular}{|ll|r|r|r|r|r|}
\hline Model & & Sum of Squares & df & Mean Square & F & Sig. \\
\hline 1 & Regression & 11.967 & 5 & 2.393 & 6.928 & $.000^{\mathrm{a}}$ \\
Residual & 12.438 & 36 & .345 & & \\
& Total & 24.405 & 41 & & & \\
\hline
\end{tabular}

a. Predictors: (Constant), 2) Global Competency \#5 - Personal adaptability to diverse cultures, 2) Global Competency \#3 Knowledge of global organizations and business activities, 2) Global Competency \#1 - Ability to work in different international settings, 2) Global Competency \#2 - Awareness of global changes and issues driving these changes, 2) Global Competency \#4 - Capacity of effective communication across cultural and linguistic boundaries

b. Dependent Variable: 6) Global Competency \#5 - Awareness of global changes and issues driving these changes 


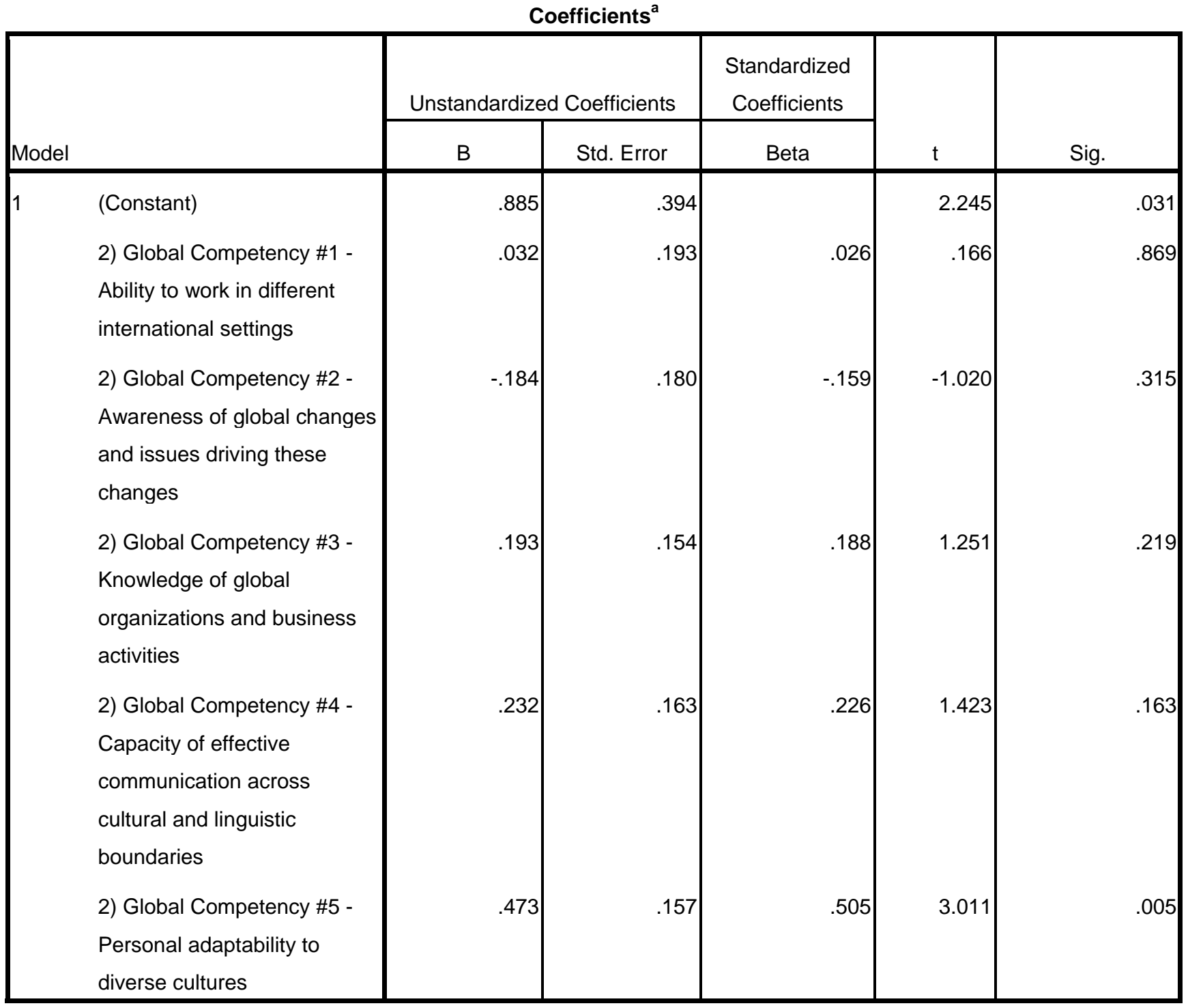

a. Dependent Variable: 6) Global Competency \#5 - Awareness of global changes and issues driving these changes 